\title{
النظام وصدع النظام في الأدب الجاهلي مستوياته ، وصوره ، ودلالاته
}

و . أحمو صلاو

مد وس بقسهر الد راسات الأدبيت

كليت دار العلوهر - جامعت القاهرة 


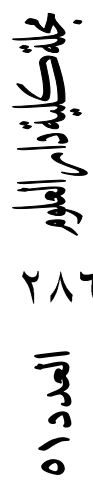




\section{ملغص:}

يروم هذا البحث التأثيل لتطبيق فكرة النظام وصدع النظام على الأدب العربي؛ حيث مثلت هذه الفكرة ركيزة أساسية لدى أصحاب المنهج البنيوي، وأفاض فيها القول يوري لوتمان بكتابه تحليل النص الشعري بوصفها بحاجة إلى تطبيق في بحال النقد الأدبي. بيد أها - على أهميتها في بنية النص الأدبي وتعدد مستوياها وصورها ودلالاتحا الفنية - لم يلتفت إليها أحد في ووطنا العربي ليجعل منها محورا لدراسة شعر شاعر أو نثر ناثر، فيمهل لها السبيل ببيان مستوياها، وما قد يحمله كل مستوى من صور ذات دلالات فنية؛ من أجل ذلك ناء هذا البحث بحمل عبء تطبيق هذه الفكرة على الأدب الجاهلي.

\section{مقلدمة:}

في عام TVY ام، أخرج الناقد يوري لوتمان كتابه القيم تحليل النص الشعري "بنية القصيدة"، وهو يعد - كما يرى مترجمه إلى العربية الدكتور محمد فتوح أحمد من أهم الوثائق النقدية التي وظفت المنظور البنيوي التحليلي في البحث الأدبي ومن

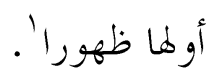$$
(1-\cdot)
$$

وقد عرض هذا الكتاب لعدد من رؤى المنهج البنيوي تنظيرا وتطبيقا، و كان من أبرز تلك الرؤى التي عرض لها الكتاب فكرة ثنائية النظام وصدع النظام، وهي ثنائية كما يظهر من معالجة لوتمان - تتسع وتضيق وفق مظهرين، أولمما: أن يكون النظام

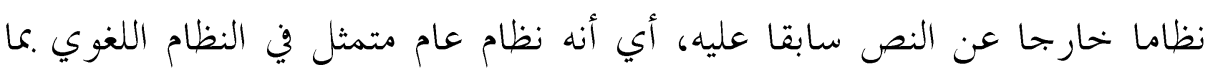
يمتلكه من قواعد نظرية يعد الالتزام بها نظاما والانحراف عنها صدعا لهذا النظام، و ونظام التقاليد الفنية التي يستطيع المتلقي أن يتعرف عليها وفقا لمطالعته الأعمال

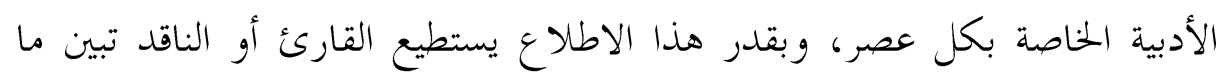

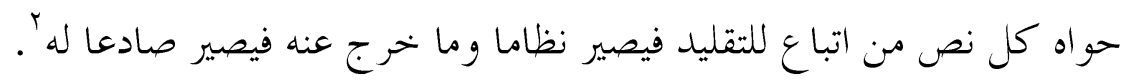


أما المظهر الآخر، فهو نتاج رؤية لوتمان إمكانية أن يعد النص بمستوياته البنيوية

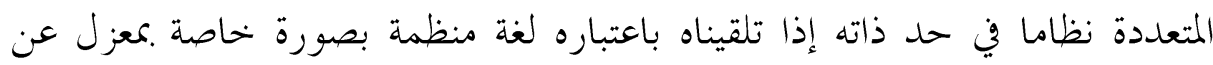

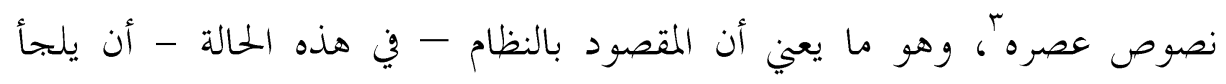
الأديب إلى تكرار قالب من قوالب أحد مستويات البنية خلال النص، وهو ما يعتي أنه قد شكل من خلال تكرار ذلك القالب نظاما، فإذا أتبع الأديب ذلك النظام .بما يمثل خروجا عليه بالتحول عن ذلك القالب أو تبديله، فقد صدع بذلك الأديب

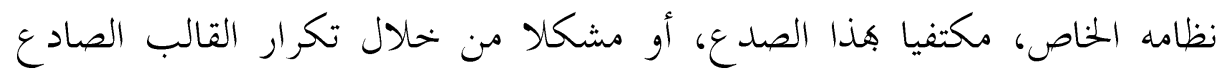

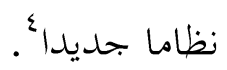
و بناء على ذلك، فإن النظام إما أن يكون نظاما مؤسسا مسبقا من خحارج النص، فهو وليد العمومية المتخذة حكم الصحيح لغة أو الشائع تقليدا، وإما أن يكون نظاما

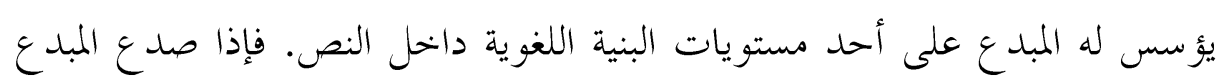

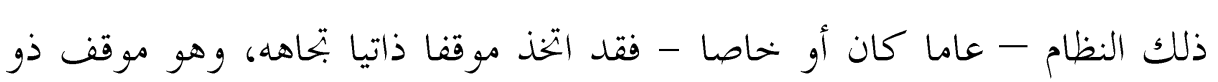

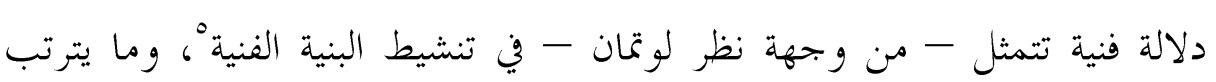
旁 عليها من إدهاش المتلقي وتحقيق أقصى حد من المعلوماتية والإمكانات الإخبارية

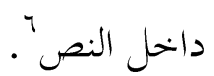
YAN $\frac{\overline{3}}{3}$

$$
(r-\cdot)
$$

وإذا كان لوتمان ذاته قد أقر بأن هذه الفكرة حين حررها بكتابه كانت مثيرة

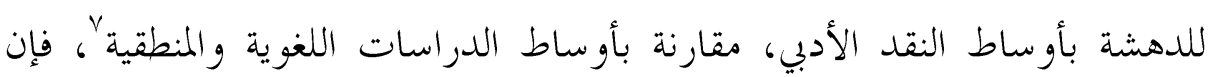
هذه الفكرة ما زالت غريبة - من حيث التطبيق - على بحال نقد الأدب العربي؛ ذلك لأن محاولة تطبيق المظهر الأول من مظهري النظام ستكون شاحبة إلى حد كبيد لندرة الأمثلة التي سنعثر عليها خلال تطوافنا بالأدب العربي عبر عصوره، خاصة لاصن القديم منهـ. 
فقد تأسس الفكر اللغوي العربي - وهو صنو الفكر النقدي- على أساس تقسيم عصور الأدب إلى عصرين: عصر الاستشهاد، وعصر ما بعد الاستشهاد. فما كان

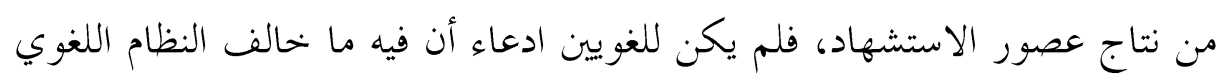

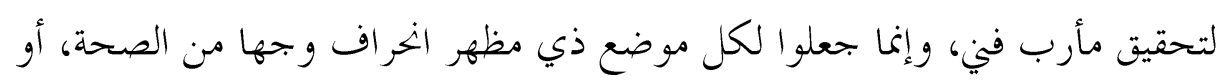

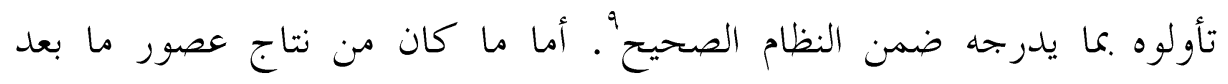

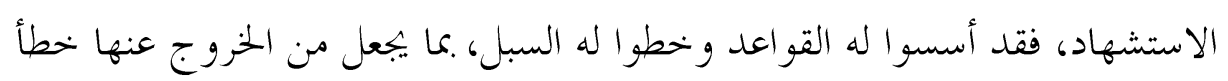
لا علاقة له بالمأرب الفي؛ فما كان من أدباء تلك العصور إلا الانصياع والاتباع.

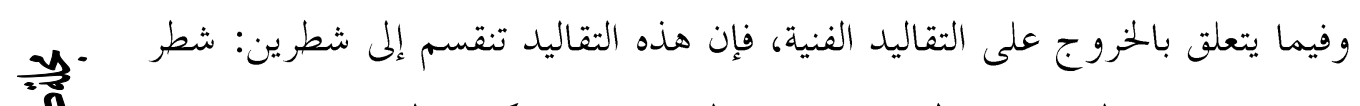

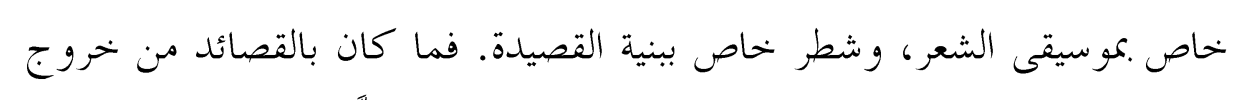

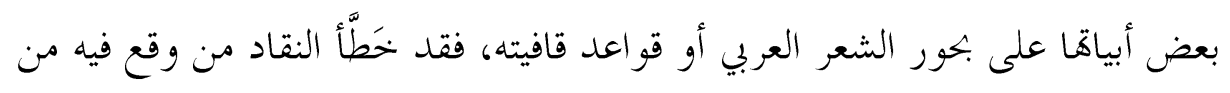

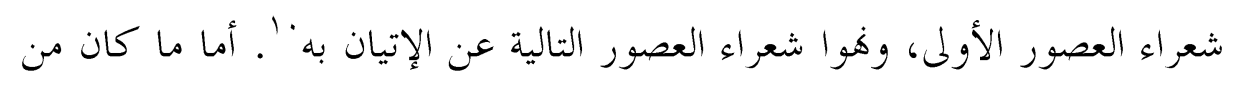

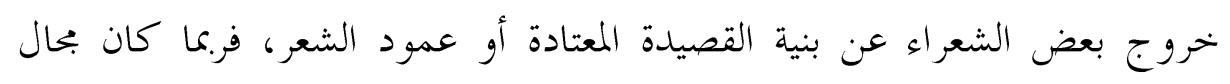

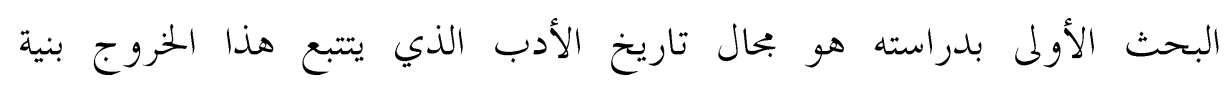
و وضمونا.

ولعل ذلك يومئ إلى أننا خلال هذه الدراسة سنستطلع فقط فكرة النظام وصدع

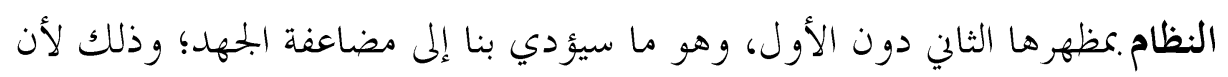
تحليل هذا المظهر خاصة يحتم علينا استكشاف القالب أو القوالب التي تُشَكَّل النظام أولا، ومحاولة كشف الحُجُب عن الدور الفين الذي قامت به هذه القو الب من خلاليال تتابعها، ثم الانتقال إلى قو الب الصدع - شكلت نظاما أو لم تشكل - لإماطة اللثام كذلك عن الدور الفني الذي قامت به"، وهو ما يعني اعتر افا ضمنيا بأن لكل عنصر من عناصر النظام وصدع النظام دوره الفني من خلال موقعه بالنص، بحيث يمثل

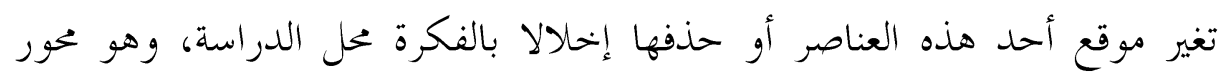

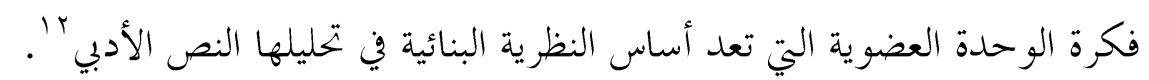




$$
(r-\cdot)
$$

ولأن هذا البحث قد أخذ على عاتقه القيام مكهمة تطبيق هذه الفكرة على شريحة من الأدب العربي، فقد آثر ألا يحصر نفسه في أحد دواوين الشعر ولا منثور الكتب هنب

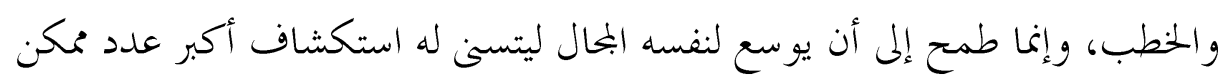

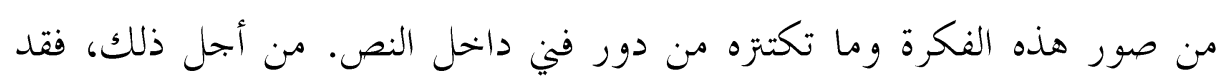

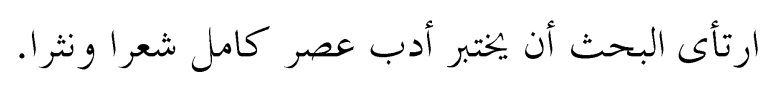

وهنا يرد السؤال: أي العصور أجدر بأن نؤسس من خحلالها تطبيقا لهذه الفكرة وبيانا

$$
\text { لمستو ياها وصورها؟ }
$$

إن أيا من عصور الأدب العربي حتى يومنا هذا لم تنبتَّ صلته عن جذورها وهورهو وصولا إلى العصر الجاهلي. وإذا كان هذا العصر هو أساس الأدب العربي في عصوره التادئ التالية، فإن

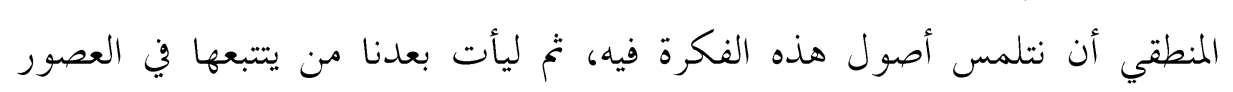
اللاحقة، ويتلمس ما أصابها من تطور مسلكا وتوظيفا؛ من أجل ذلك كان كان اختيارنا

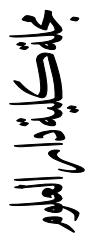

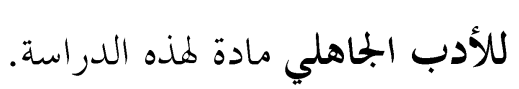

$$
(\varepsilon-\cdot)
$$

فإذا طالعنا مستويات ظاهرة النظام وصدع النظام في الأدب الجاهلي، فإننا بجد لها rq. عدة مستويات، هي: النظام الصرفي وصدعه، والنظام الأسلوبي وصدعه، ونظام الإيقاع وصدعه، و النظام المُركَّبَ وصدعه. ولعل من يطالع هذه المستويات يتبادر إلى ذهنه سؤالان مؤداهما: أين النظام المعجمي من بين هذه الأنظمة؟ ولماذا لم نطلق على (نظام الإيقاع) (النظام الصوتي)؛ لكون

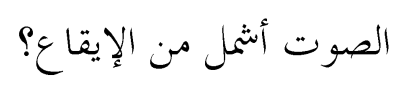
إن الإجابة عن هذين السؤالين تخرج من مُعِين واحد، هو ملاحظة ما سبق من حديثنا حول المظهر الثاني من مظاهر فكرة النظام وصدع النظام؛ وذلك لأننا ذكرنا

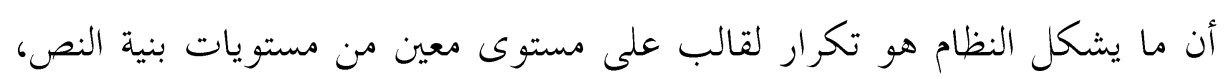


أي أن النظام ليس تكرارا لمادة لغوية صوتية أو معجمية كالمعهود في النقد العربي، إنه ليس حشدا لصوت معين بالبيت الشعري، ولا متابعة لتوظيف جذر معجمي محدد، وإنما هو تكرار لقالب من القوالب التي تتيحها مستويات اللغة؛ ولذلك فإن المستوى المعجمي سيكون .معزل عن فكرة النظام وصدع النظام، كما أن المستوى الصوتي

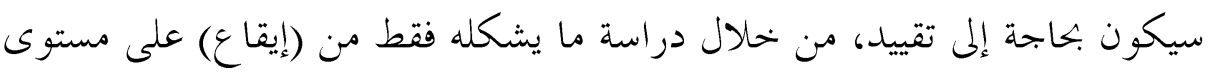
البيت و القصيدة أو على مستوى الجملة النثرية.

\section{(1)}

离. rq1

$\overline{3}$
$\frac{3}{0}$

فإذا بدأننا نتحسس طريقنا لظاهرة النظام وصدع النظام عبر الأدب الجاهلي وفق ترتيب المستويات الذي ذكرناه سلفا، فإننا بند أن النظام الصرفي وصدعه يتخذ عدة صور تختلف جمالياها تبعا لدلالات القوالب الصرفية المؤسسة للظاهرة والمادة المعجمية التي تشكلها هذه القوالب و السياق الذي ترد به.

$$
(1-1)
$$

فقد يتشكل النظام الصريف من خلال تكرار ورود الفعل في صيغة زمن معين، و بذلك فإن هذه الصيغة قد وضعت المتلقي في إطار نظام ذلك الزمن، ثم يأتي صدع

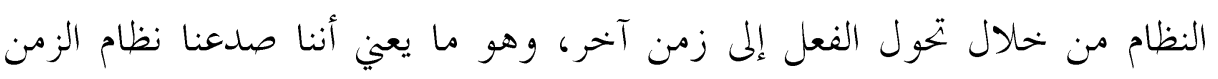

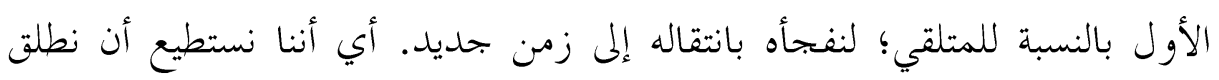
على هذه الصورة من النظام وصدعه "النظام الصرفي الزمين وصدعه". ومن المعلوم - بادي الرأي - أن الأصل في الخطاب أن يكون على نسق زمين

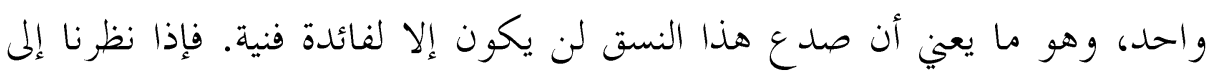

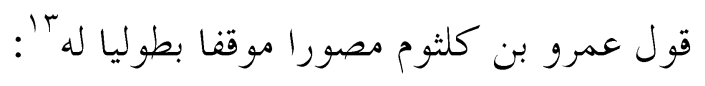

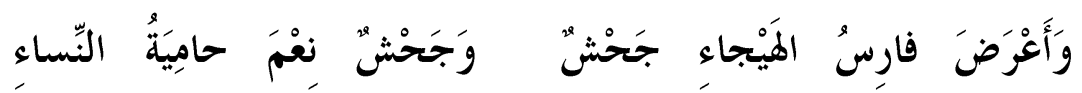

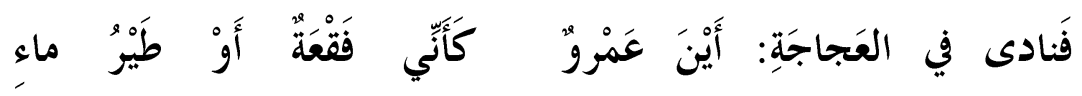
فَأَطْعَنُهُ وَقُلْتُ 
فإننا نلفي الشاعر في أول بيتين يضع المتلقي في إطار نظام الزمن الماضي "أَعْرَضَ ..

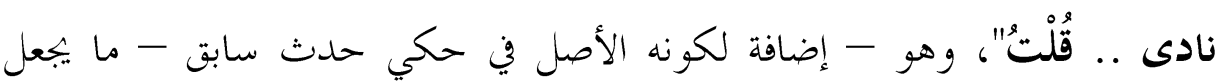
المتلقي يستقبل ويتناول هذا الخبر على أنه حقيقة قد حدثت وتأكدت، و حين يتحقق

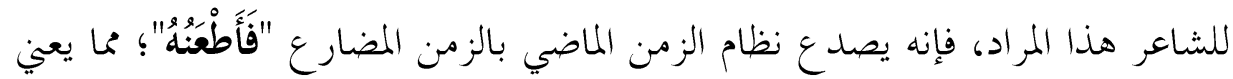
أن الشاعر أراد أن يُحْضِر مشهد هذا الفعل خاصة بين يدي المتلقي مشاهدا له مقرا به؛ وذلك لما لهذا الفعل من أهمية؛ لكونه يمثل محور المشهد الذي أتت بقية عناصره كلها خحادمة له 'أل$$
(r-1)
$$

وقد يأتي النظام الصرفي الزمين وصدعه على عكس ذلك بحيث يتشكل النظام • و ومثال ذلك ما ورد بإحدى لاميات عبيد بن الأبرص حين عيرته زوجته بشيبه وهرمه وما نتج عن ذلك من قلة ماله وانفضاض عبيده عنه. حيث أخذ يعدد حسنات ماضيه وشبابه في أربع لوحات متتالية، فقال في اللوحة الأولى مالى

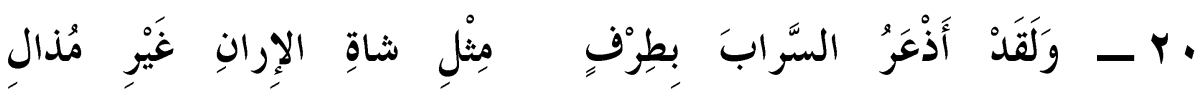

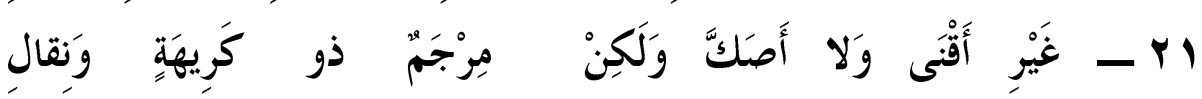

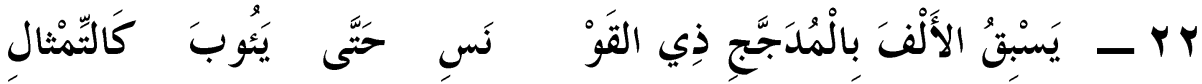

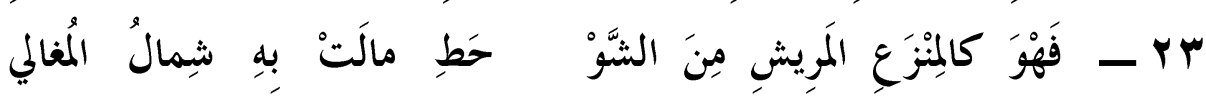

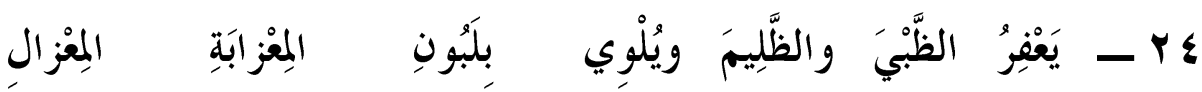
وفي الثانية 17

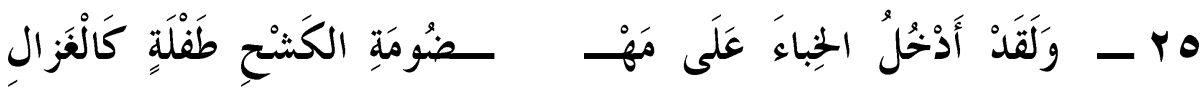

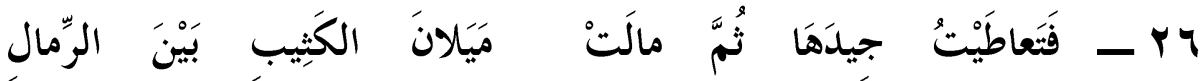

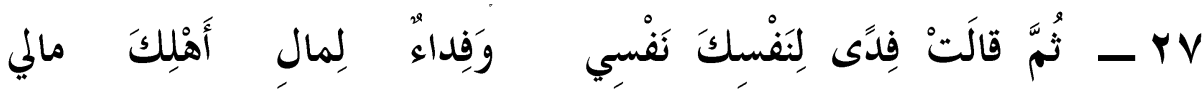


و في الثالثة '

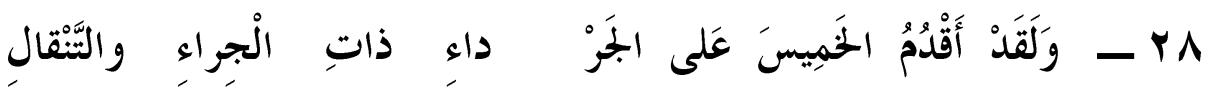

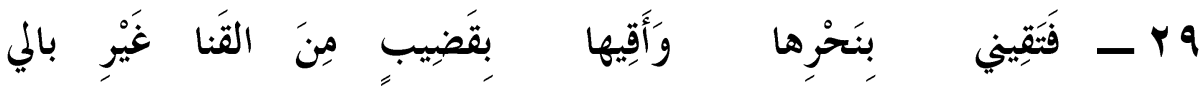

$$
\text { وفي الرابعة' }
$$

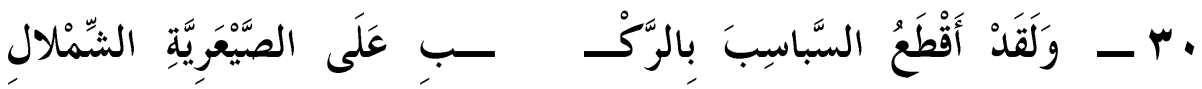

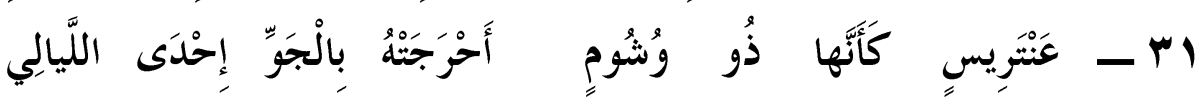

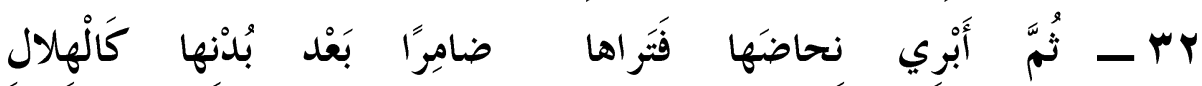

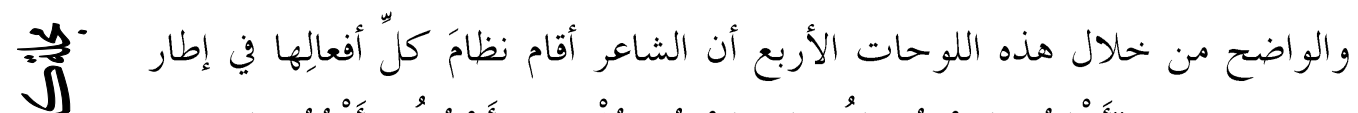

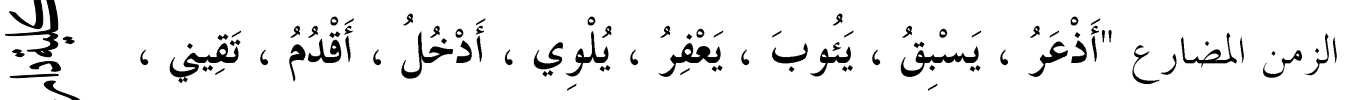

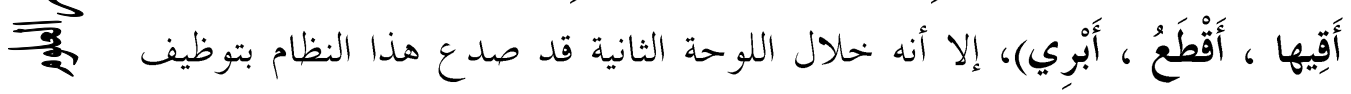
rar

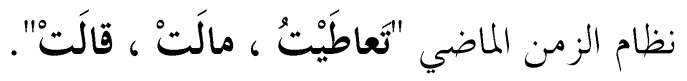

وبالمقارنة بين هذا النموذج الشعري وسابقه، بند أن نظام هذا النموذج يخالف سابقه في أصل ما وضع عليه النظام الصرفي الزمني؛ وذلك لأن تأسيس النظام في نموذجنا هذا أتى على خلاف الأصل، فالأصل في هذا المقام هو توظيف صيغة الزمن الماضي لكونه يتناول ذكريات سالفة، لكن الشاعر هنا أسس النظام على الزمن

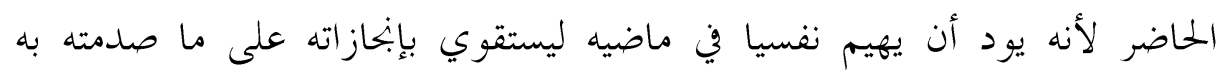
زوجته من حاضره التعس الشقي، فنقل هذا الماضي إلى الحاضر إحياء له وتشبثا به

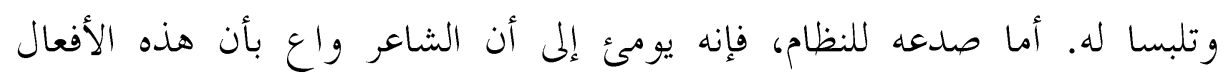
الصادعة الثلاثة صارت من الماضي؛ لأها أفعال متعلقة بلهوه أيام الصبا؛ فأبقى عليها

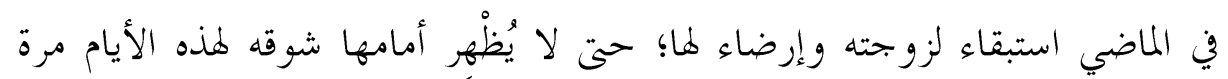
أخرى، وحتى يثبت لزوجته أها تكفيه ولا يروم سو اها. كما أن صدع النظام خلال هذه الأفعال الثلاثة يعني أن هذه الأفعال خحاصة ما يود لئد الشاعر الوقوف عنده ولفت الانتباه إليه. ولعل الشاعر أراد من خلال الوقوف على إنى 
الفعلين الأولين بيان أنه ما أراد بذذه اللوحة سرد ما تمتع به خلال مرحلة شبابه في

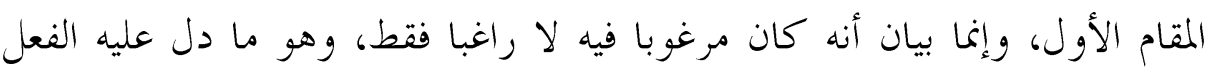

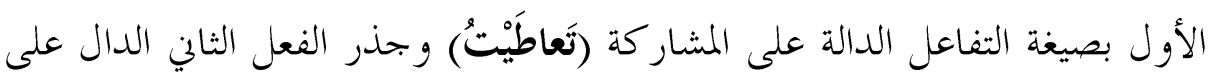
الإقبال (مالَتْ). أما الفعل الثالث، فهو فعل القول الذي لا تتم دلالته إلا ببيان جملة

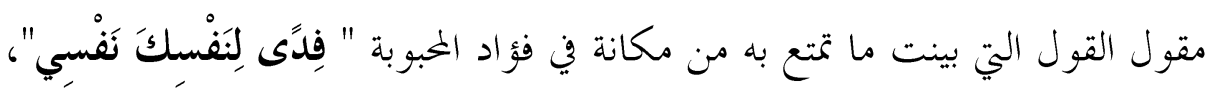

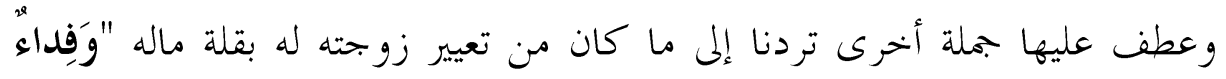

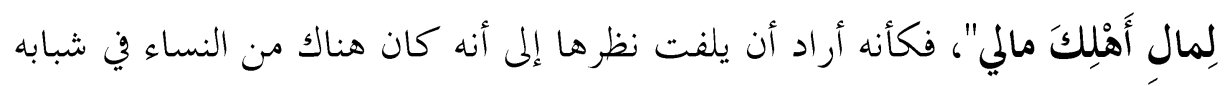
من كانت تود أن تفديه بأن تنفق من أجله مالها كله، و كأنه يشير - بحرد إشارة -

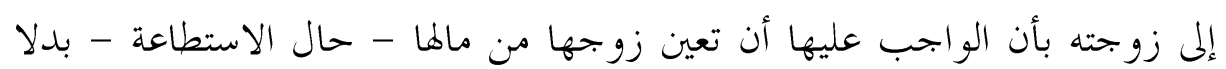
من أن تعيره بقلة ماله. وفي مثال آخر، يقول عنترة

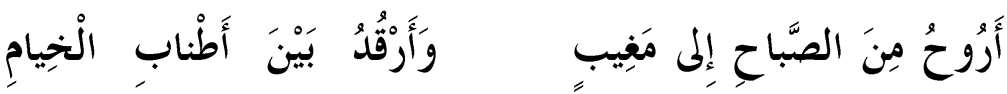
أَذَلَّ لِعَبْلَةٍ مِنْ فَرْطِ وَجْدِي

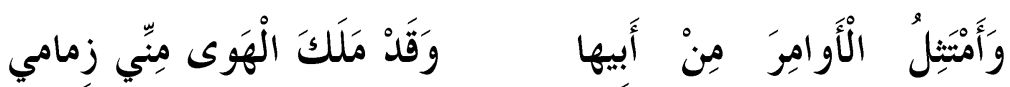

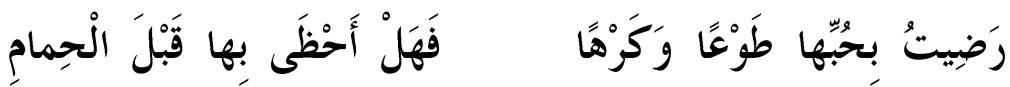

إن الثاعر يستخدم في وصف حالته بالأبيات الثلاثة الأولى الأفعال المضارعة "أَرُوحُ

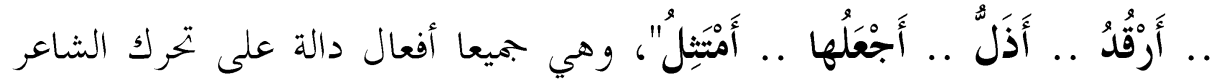
كحيط دائرة مفرغة من الأفعال التي تتجدد باستمرار بلا قدرة لديه على الفكاك منها، رغم ما في بعضها من إذلال له و إهانة. و بعد هذا النظام من الأفعال المضارعة، يظهر فعل ماض واحد صاد مادع لهذا النظام ليبين عن أنه أقوى من كل تلك الأفعال السابقة لكونه علة لها جميعا، وقد وقعت تلك العلة بالشاعر، واستقرت بنفسه، فقد "رَضِيَ" بحبها، وقُضِيَ الأمر. 


$$
(r-1)
$$

فإذا جمعنا بين النطاق الزمني الذي يتيحه المستوى الصرفي للأفعال وإمكانات صياغة

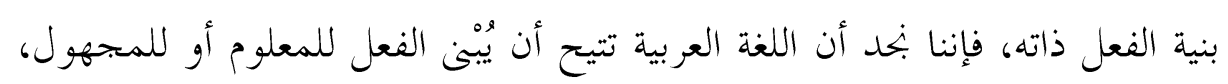

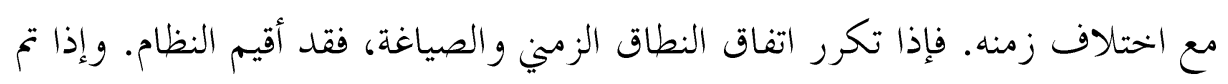
الخروج عن هذا النطاق و الصياغة المصاحبة له، فقد صدع النظام.

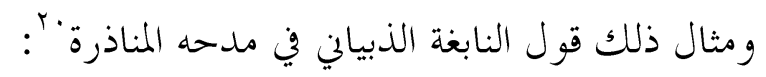

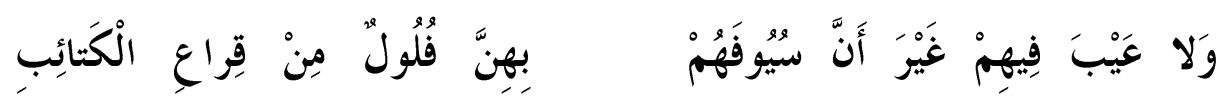

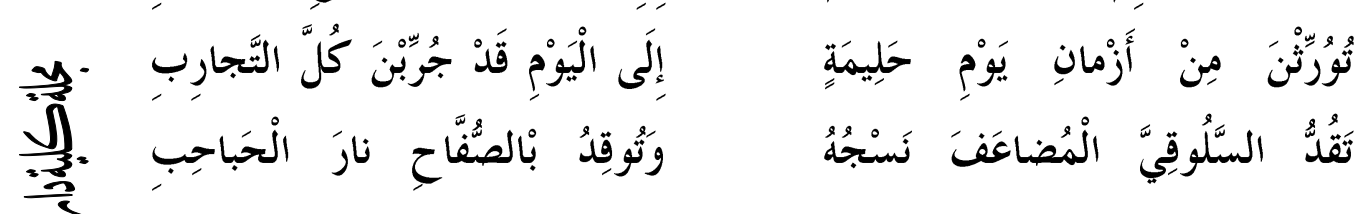

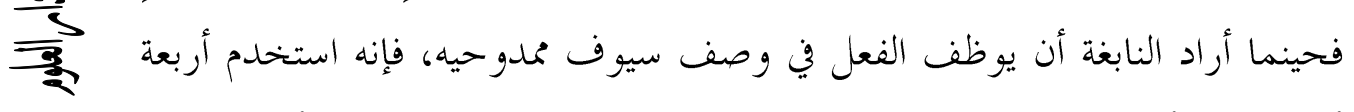

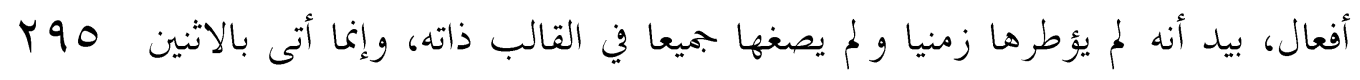

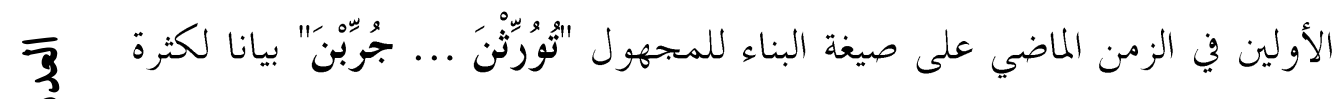
تعاهد هذه السيوف بين أيدي الكماة على مدى زمين موغل في القدم. فإذا تم

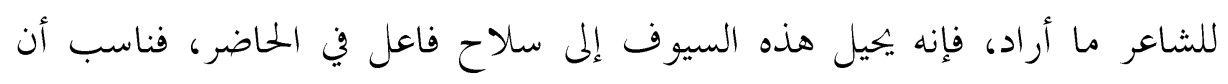
يصدع نظام البناء للمجهول بالبناء للمعلوم مع الانتقال للزمن المضارع في الفعلين " تَقُدُّ ... تُوقِدُ "؛ ليحيل السيوف لمّاء كانت عليه من حال تجريب إلى ما صارت إليه

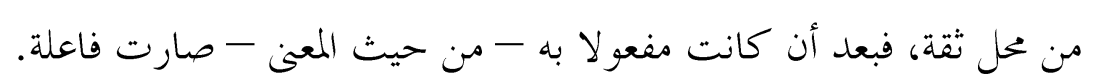

$$
(\varepsilon-1)
$$

كان كل ما سبق خاصا بالإمكانات الصرفية للفعل بأزمنته وصياغاته المختلفة. فإذا ولينا وجوهنا شطر الجمع بين المشتقات الفعلية وتظيراها الاسمية، فإننا نلفي صورة للظاهرة محل الدراسة يمثل توظيف الاسم فيها النظام الصرفي، ويمثل توظيف الفعل وتل وتئل

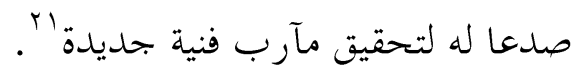

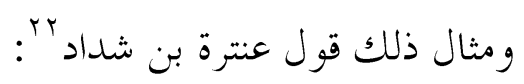




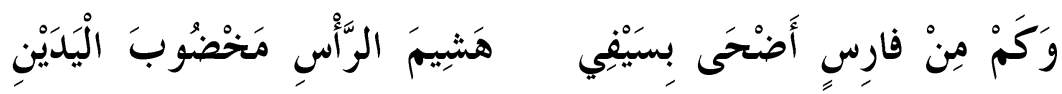

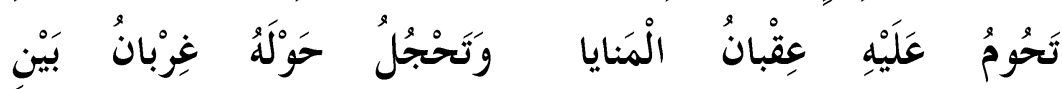

فالشاعر في هذين البيتين يقيم مفارقة أو ثنائية ضدية بين حال الثبات التي حلت على لي لئي الفارس المقتول وحال سياقه الخارجي المتحرك؛ ولذلك فقد أقام نظاما في البداية من

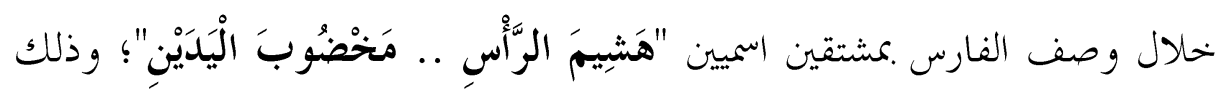

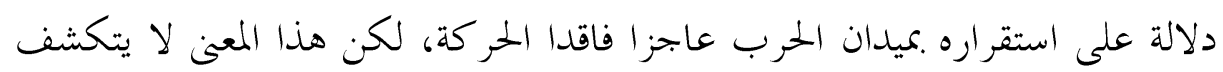

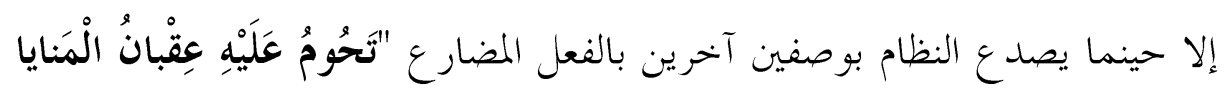

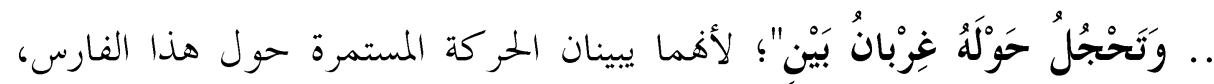

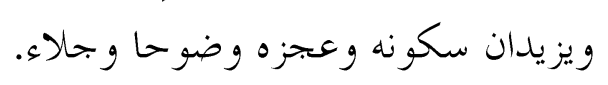

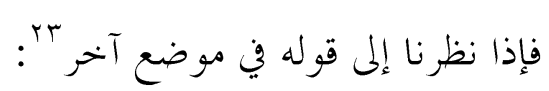

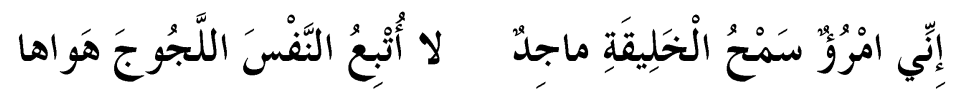

فقد وصف الشاعر نفسه في هذا البيت بصفات كلها معنوي نفسي، وإذا كان بالنفس ما هو مركوز فيها من خير، وما هو من نوازع الشر، فقد عبر عن المركوز

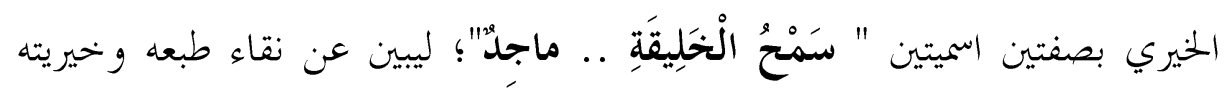

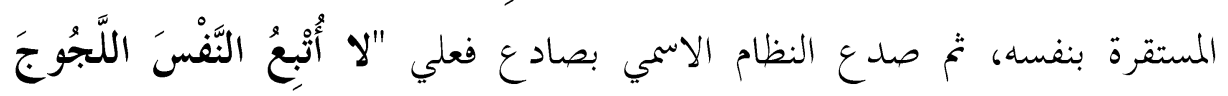
هو اها"؛ وذلك ليقيم المفارقة، حيث يبين عن أن نوازع الشر ليست مستقرة بنفسه، وإنما تتلجلج فيها بين حين وآخر، فتظهر مروءته في عمله على كبح تلك النوازع التي تتجدد لجاجتها.

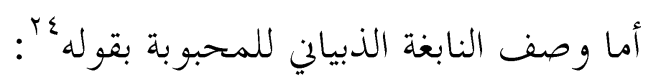

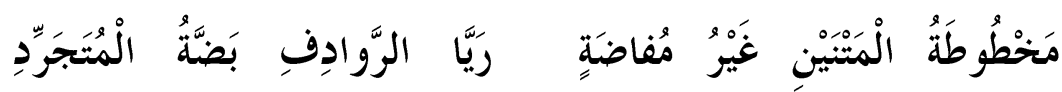

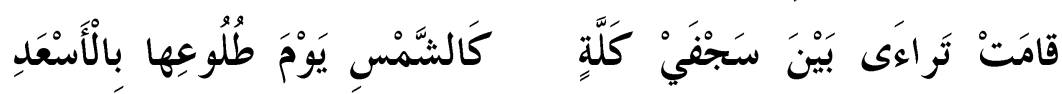
فمن الجلي في هذه الصورة أن الثاعر حينما أراد أن يصف المحبوبة بصفات مقطعية

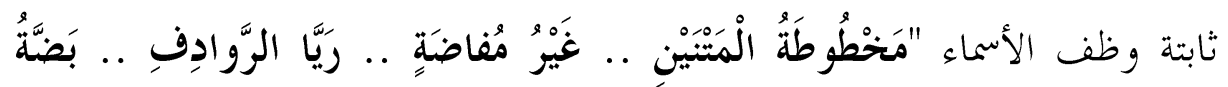


الْمتتَجَرِّدِ، فإِا أراد الشاعر أن ينتقل من الجزءء إلى الكل، فقد ناسب أن يصورها بصورة متحر كة؛ ليظهر جمال كل موضع منها حال حركتها؛ وليضفي عليها نوعا

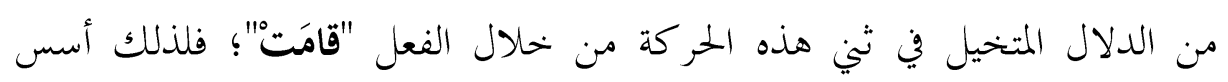
الشاعر نظاما اسميا شغل بيتا وصفيا كاملا، ثم صدعه في طليعة البيت التالي من

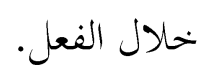
وقد بند هذه الصورة كذلك في فن الخطابة، وذلك مثل ما ورد في خطبة قس بن

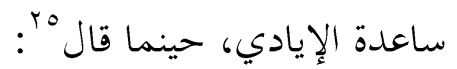

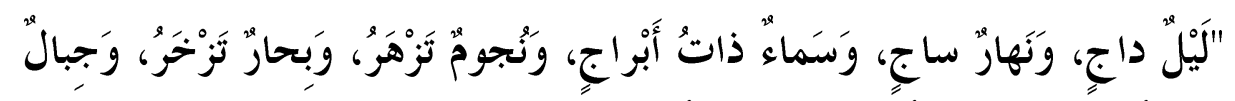

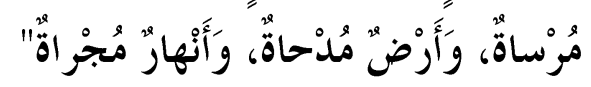
فالخبر في الجمل الثلاث الأولى ومثيلاقّا الأخيرة قائم على الاسم الدال على أن هذه وته

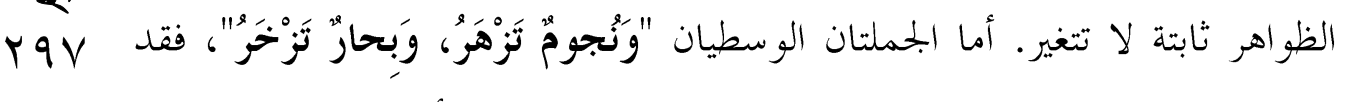
قام الخبر فيهما على الفعل المضارع الدال على التجدد مرة تلو أخرى. وهنا يأتي السؤال: لماذا وضع قس بن ساعدة الجملتين ذواتَي الخبر الجملة القائمة

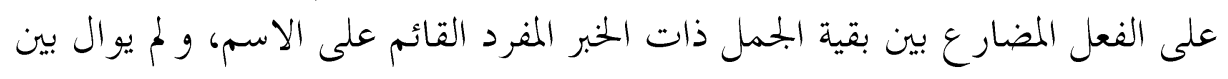

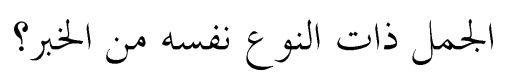

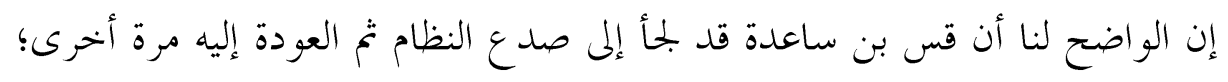

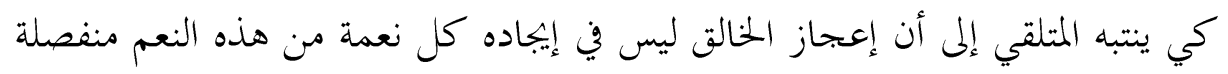

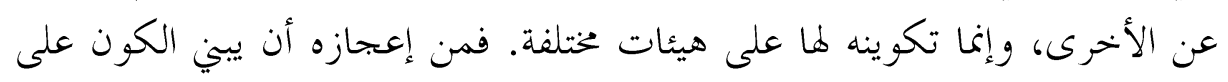

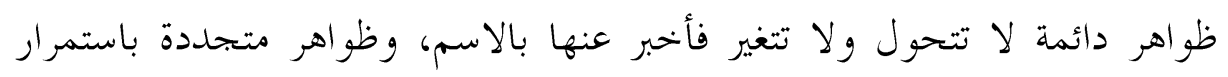

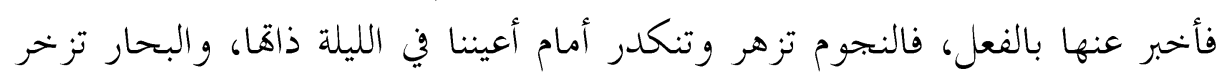
و وتغيض طورا بعد آخر.$$
(0-1)
$$

ومن ثراء اللغة العربية أها تتيح للأسماء والأفعال عدة صيغ واشتقاقات تختلف دلالة

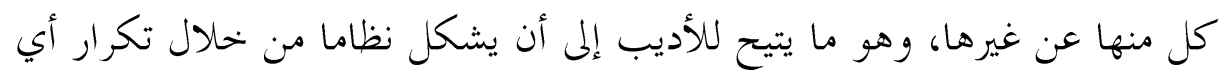

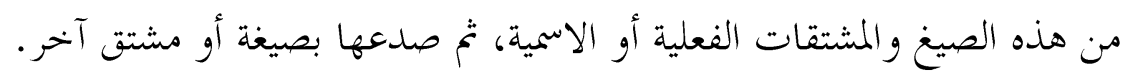


ومثال ذلك ما نطالعه في خواتيم معلقة عبيد بن الأبرص بلوحة صراع اللقوة وَالصَّيْدُ مِنْ تَحْنِهِا مَكْرْوبُ

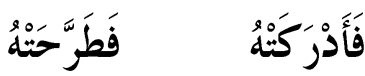

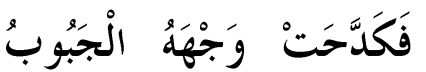
وَوَضَنَعْنُهُ فَزَنَحَتْهُ

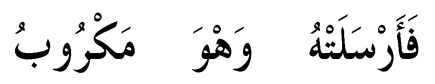
فَرَفََّعَنُْ فَعَاوَدَتْهُ يَضْغْو وَمِخْلَبها فِي دَفَّهِ

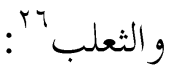

إن الشاعر يوالي منذ أن أدركت اللقوةٌ الثعلبَ بين أفعال ماضية على صيغة (فَسَّلَ)

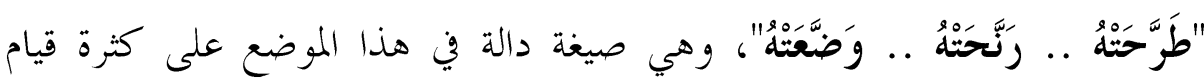
اللقوة بكل فعل من هذه الأفعال، وهو ما يعكس القوة والشدة والسرعة في تنفيذ

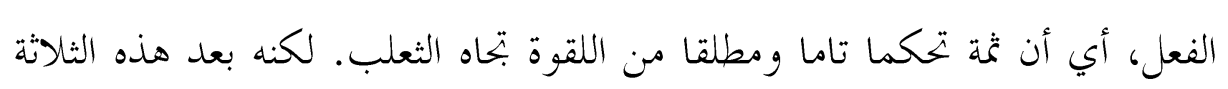

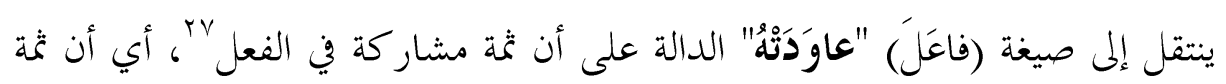
إشارة إلى أن الثعلب خلال هذه اللقطة في آخر فرصة له للمقاومة أو الهرب، فإن إن إنهان فشل فيها، فستكون فايته محتومة. فإذا عاد الشاعر إلى صيغة النظام مرة أخرى إلى

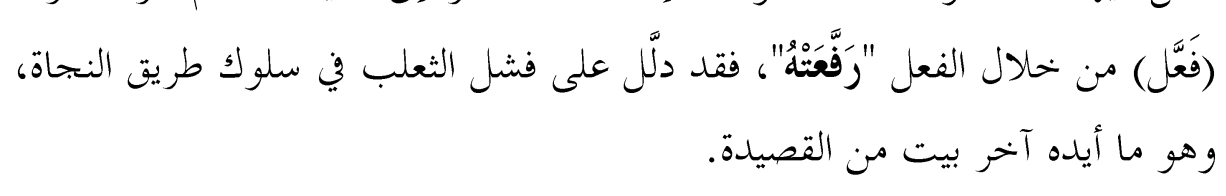

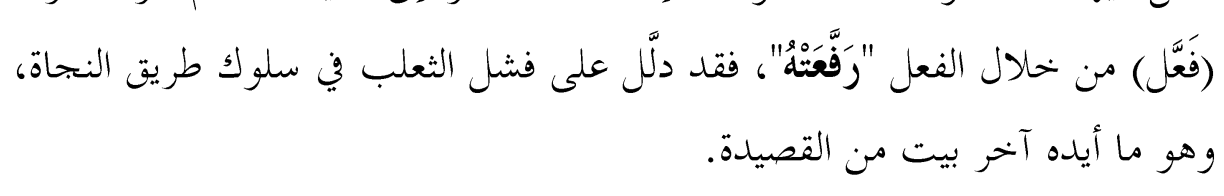

\section{(r)}

فإذا نظرنا للنظام وصدع النظام على المستوى الأسلوبي، فإننا بند أن اللغة العربية تمتلك عدة صور لتحقيقهما. فقد يتحقق النظام وصدعه على المستوى الإسنادي، كما قد يحدث على مستوى الروابط بين الجمل، أو يحدث على مستوى الضمائر.

$$
(1-r)
$$

فاللغة العربية تمتلك نوعين من الجُمَل حال الإخبار، هما الجملة الفعلية والجملة الاسمية؛ مما يمكن الأديب من أن يصنع نظاما من خلال تكرار أحد هذين النوعين، تم

$$
\text { يصدعه من خلال النوع الآخر. }
$$


ففي إحدى خواتيم مدائح النابغة الذبياني للنعمان، بخده يقول

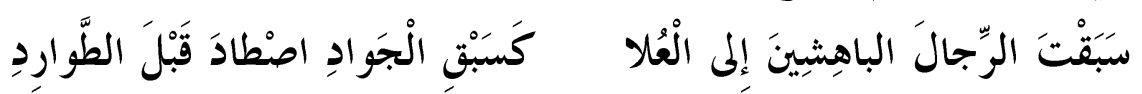

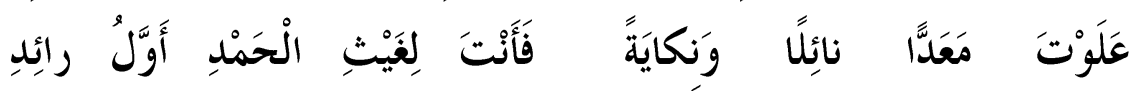
فالشاعر مدح النعمان أولا بجملتين فعليتين قائمتين على فعلين دالين على التقدم

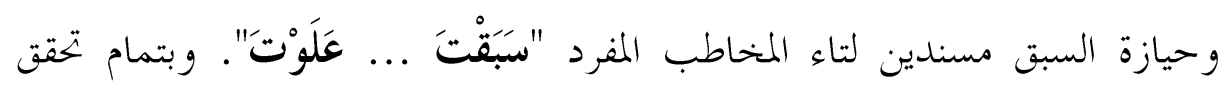
السبق والتقدم من خهلال نظام الجملة الفعلية، يرى الشاعر أن الأنسب أن يختم القصيدة بما يدل على تحقق النتيجة وثبوها من خلال جملة المية يمثل ضمير المخاطب

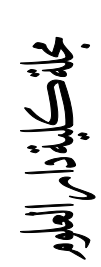
المفرد مبتدأها، مخبرا عنه بخبر مفرد قاطع لا يحتمل الشكك ولا التردد "أَوَّلُ رائدِ".

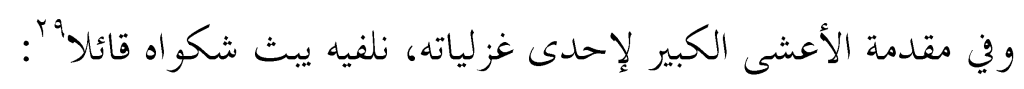

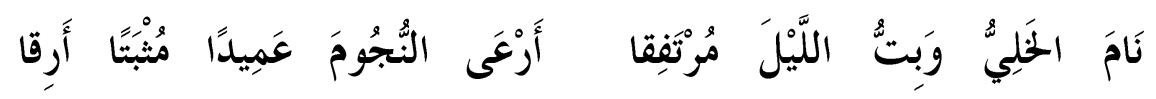

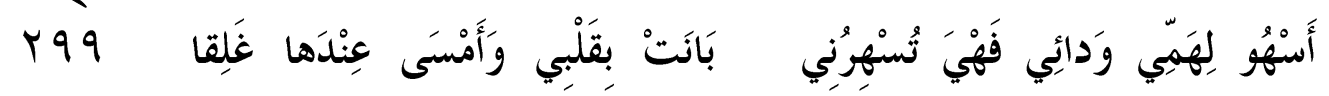

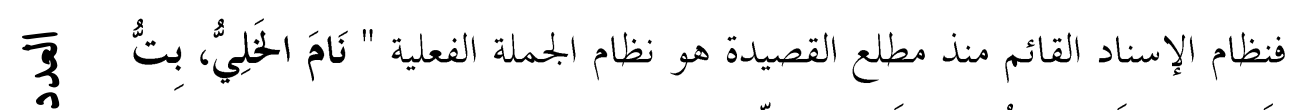

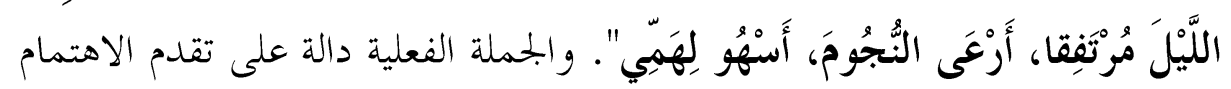
بالحداث على المُحْدِث؛ وذلك لأنه يريد أن يقيم مفارقة بين فعل الحنلي "نَامَ" وأفعاله

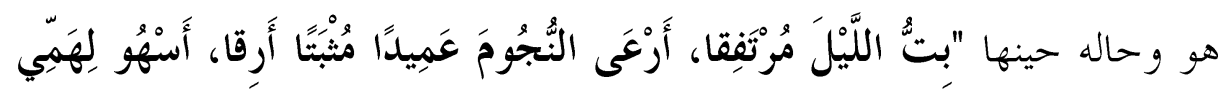
وَدائي"؛ ليستجلب تعاطف المتلقي بصورة عامة. فإذا ما تحقق له ذلك، فإن المتلقي سيسأل ضرورة عن سبب حالة الشاعر وما حل به من عذابات الحبب، فيصدع الشاعر هنا نظام الجملة الفعلية بالجملة الاسمية التي يتقدمها الضمير الدال على علة

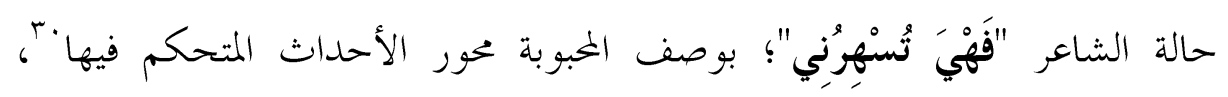

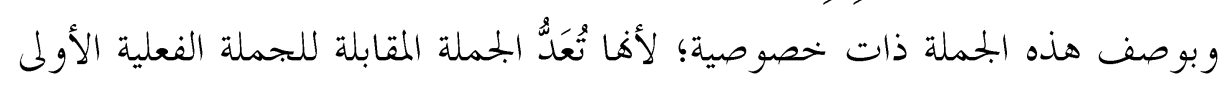
"نَامَ الحَلِيَّ"؛ وذلك تبعا للمطابقة الواقعة بين "نام ... تسهربي"، لكن الفاعل في الجملة الأولى يظهر أن الخلي أمره بيده؛ لانتفاء المنغص، أما الجملة الأخرى فتجعل

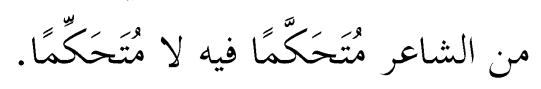




\section{$(Y-Y)$}

فإذا نظرنا إلى ما تمتلكه اللغة العربية من أدوات ربط بين الجمل، فإننا نلفيها غنية كما يبين عن علاقة الجمل ببعضها زمنا وسببا؛ بما يمقق داخل النص الأدبي - خحاصة حال إقامة نظام من خلال تكرار توظيف أحد الروابط، ثم الانتقال منه لغيره دلالات فنية.

ومثال ذلك قول النابغة الذبياني في وصفه لوحة لإحدى قصص الطرد بين الثور

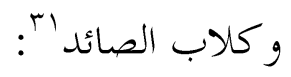

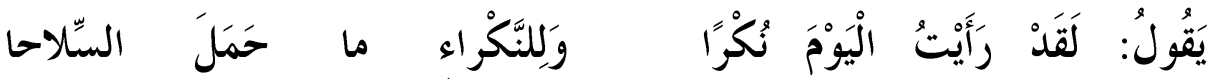

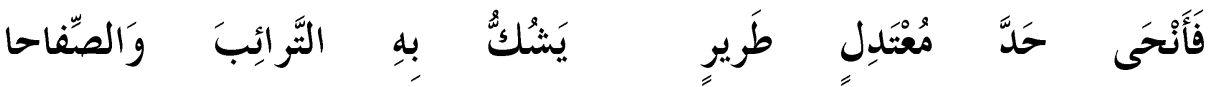

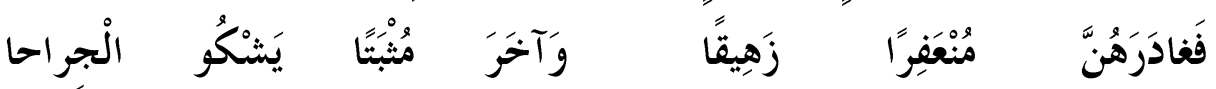

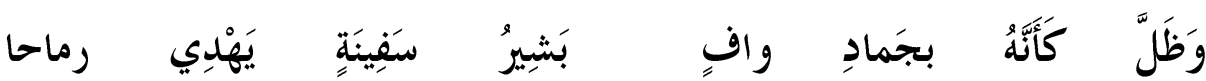

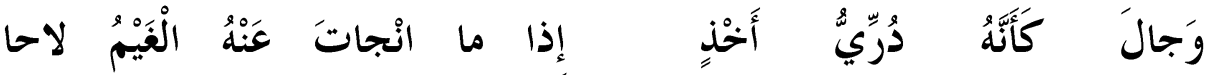
إن الشاعر في مبدأ تعرف الثور على الكلاب واقتر اهـا منه، قد أتبع فعل الرؤية " رَأَيْتُ " بفعلين صادرين عن الثور موجهين للكلاب مسبوقين بفاء العطف، أولهما " فَأَنْحَى " الذي تدل الفاء العاطفة له على خطورة الموقف ورجاهزية الثور وتمام

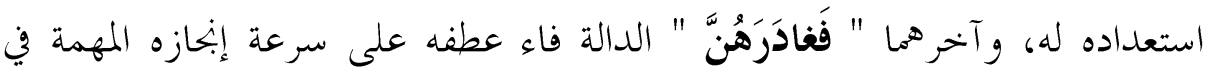
أقصر وقت تبعا لما يمتلكه من سلاح نافذ وسرعة كبيرة ومهارة فائقة. وبذلك فقد أوحى نظام العطف بالفاء خلال هذين الفعلين بتوتر الموقف. فلما زالت الخطورة،

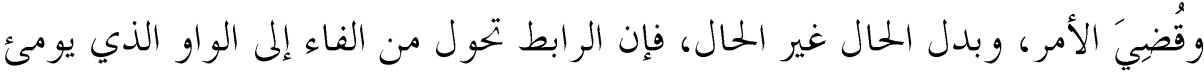

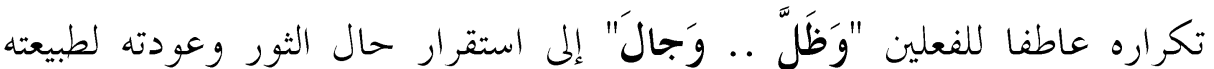
الهادئة التي ناسبت الصورة الاستعر اضية التي رسمها الشاعر في البيت الأخير:

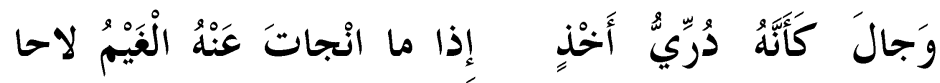




$$
(r-r)
$$

وقد تحص ظاهرة النظام وصدع النظام الضمائر على المستوى الأسلوبي. أي أن

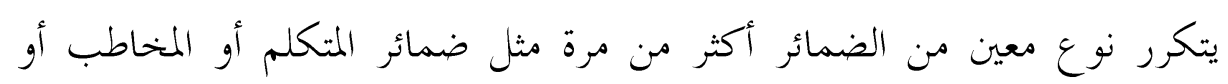

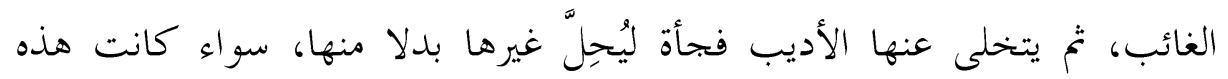

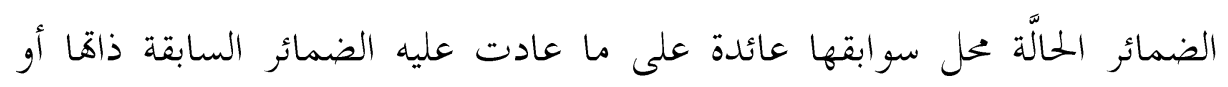
عائدة على مرجع آخر. ويعني هذا أن نظام الضمائر وصدعه يخالف الالتفات كما عرفه النقاد والبلاغيون

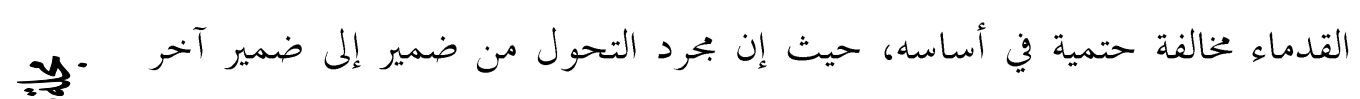
变. T.

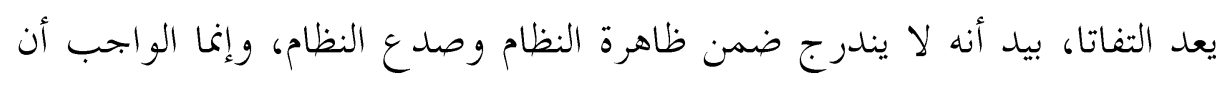

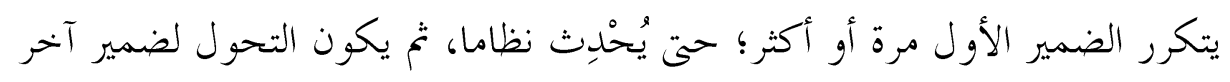
صدعا لهذا النظام.

كما قد تخالف فكرة نظام الضمائر وصدعه فكرة الالتفات لدى القدماء في أمر آخر خخالفة غير حتمية؛ وذلك لأفا تشمل التحول من نظام ضمير معين إلى ضمير آخر، حتى إذا كان هذا الضمير الآخر يعود على مرجع مغاير لما عادت عليه الضمائر التي أحدثت نظاما في الأساس.

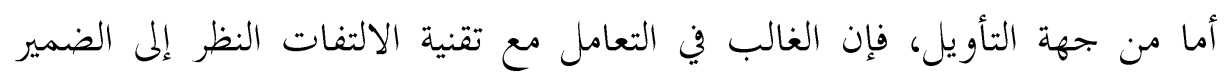

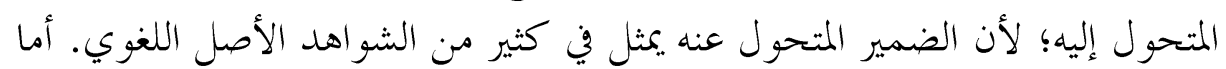

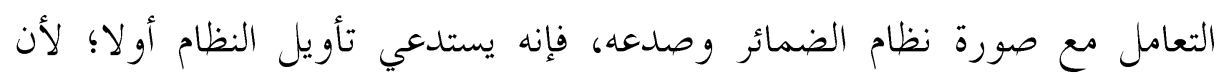

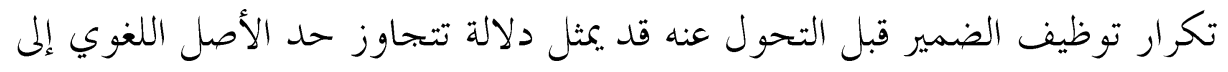

$$
(1-r-r)
$$$$
\text { التوظيف الفني. }
$$

فإن رمنا تطبيقا لهذه الفكرة على الشعر الجاهلي، فإننا نلفيها متحققة لدى عروة بن

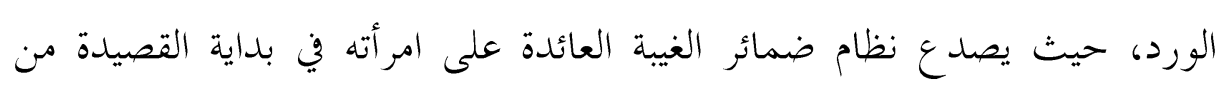
خلال التحول عنها إلى ضمير المخاطبة بالبيت الرابع بr : 


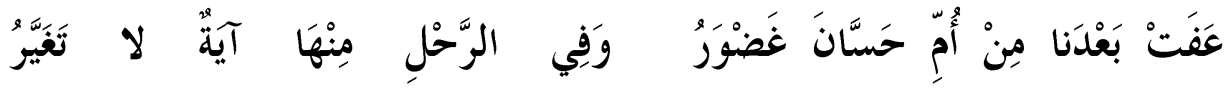

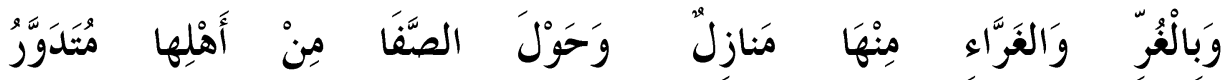

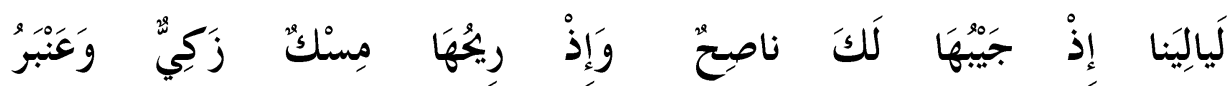

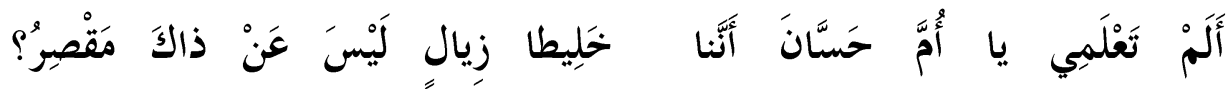
فقد أسس عروة نظام ضمائر الغيبة بعدد وافر من الضمائر العائدة على المرأة "مِنْهَا ،

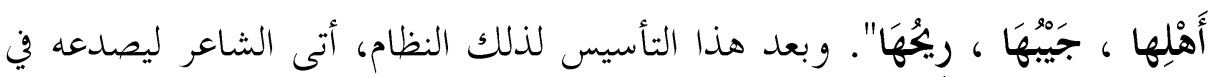

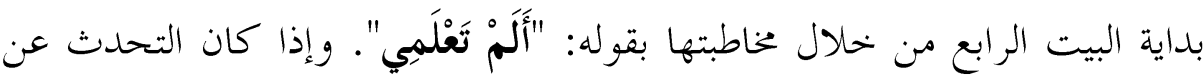

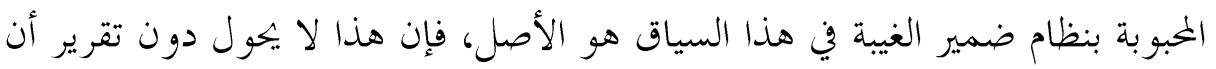

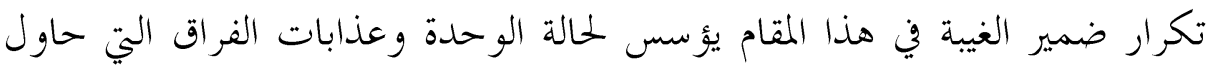
الشاعر أن يتغلب عليها من خلال استحضار الخبوبة بنظام ضمير المخاطبة.

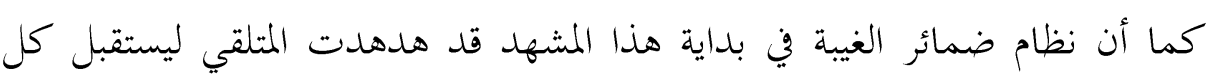

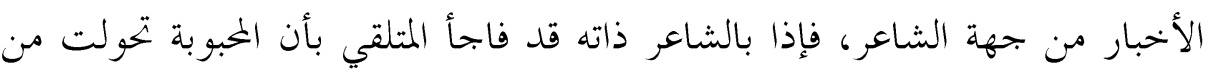
مشهود عليها إلى شاهدة من خلال استحضارها وتو جيه سؤ ال لها.

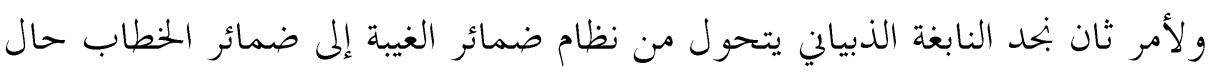

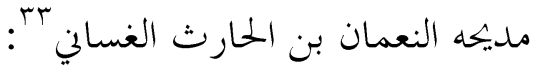

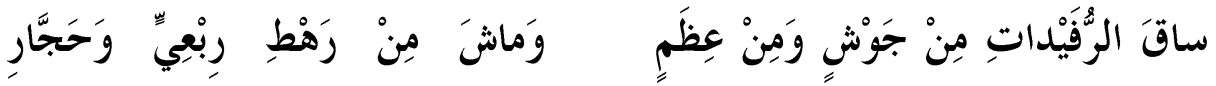

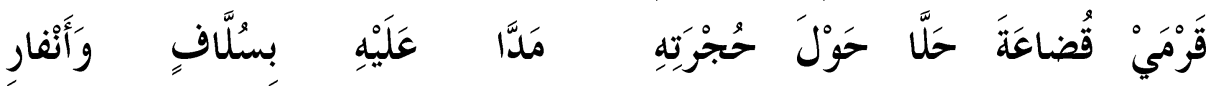

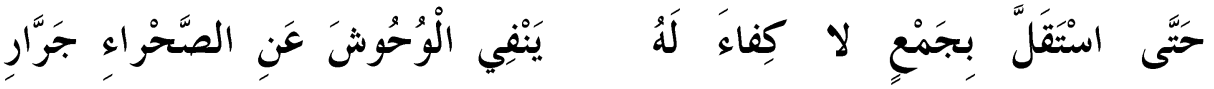

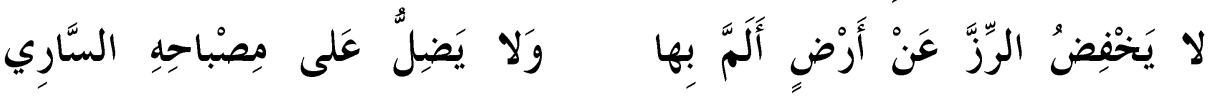

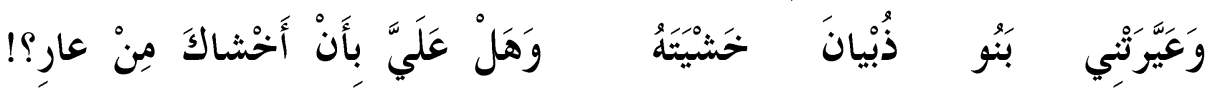

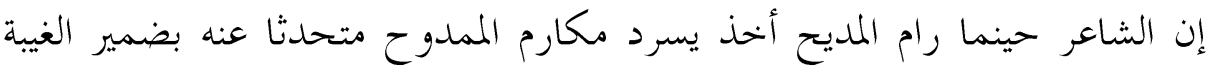
نفيا للتملق أو النفاق وسعيا لتأكيد موضوعية العرض " ساقَ (هو) .. ماشَ (هو) .. 


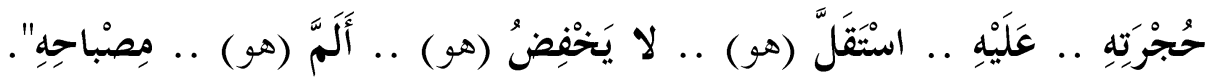

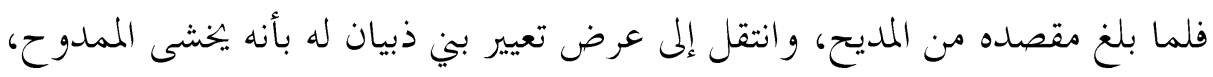

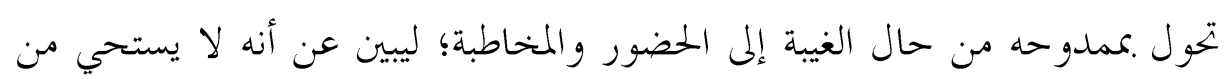

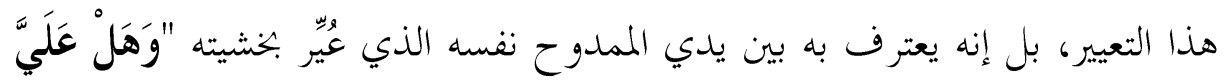

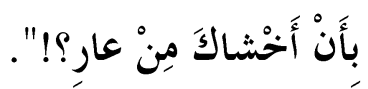
ولأمر ثالث بند الأعشى في حديثه عن ناقته يصدع نظام ضمائر الغيبة بضمائر

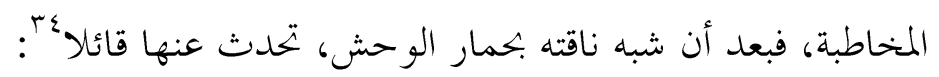

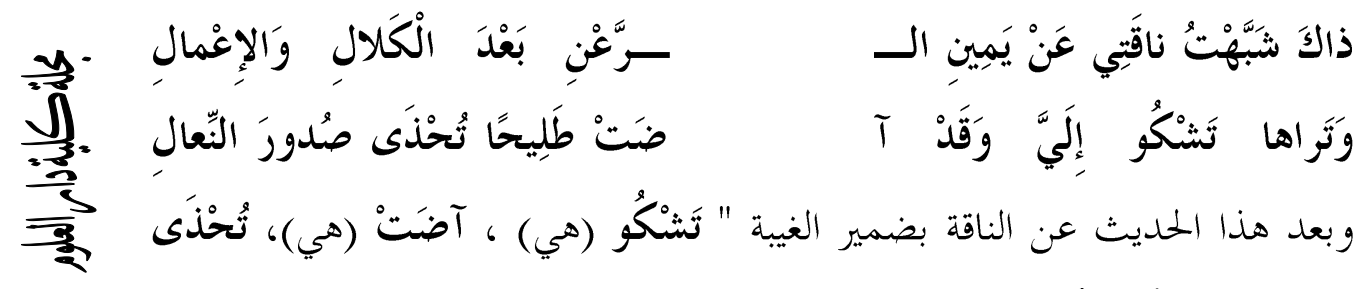

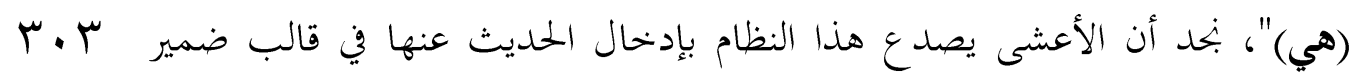

سـسنع وَلا مِنْ حَفَا وَلا مِنْ كَلال

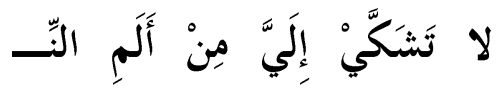

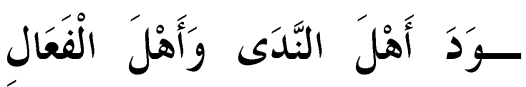

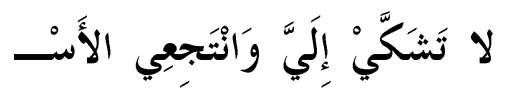

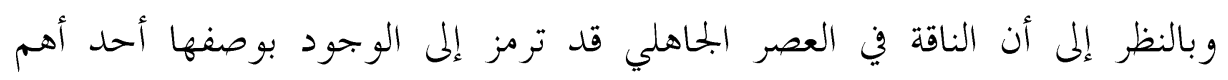

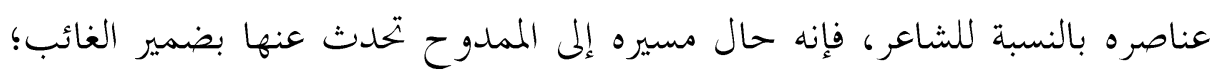

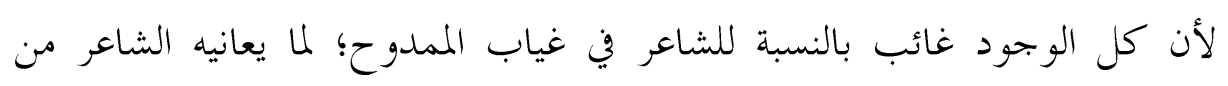

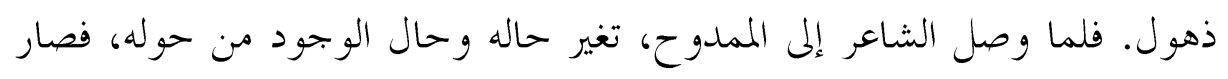

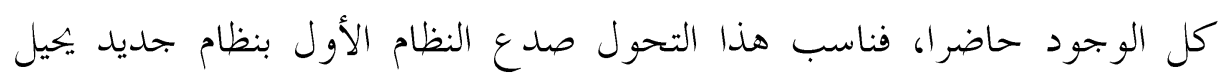

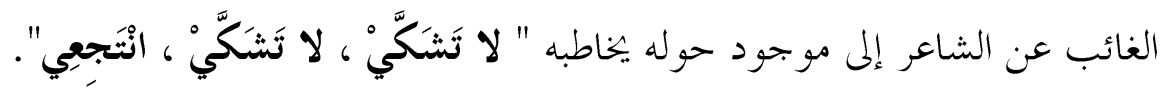

$$
(r-r-r)
$$

وحين نستشرف صور عودة الضمائر الصادعة للنظام على مرجع مغاير لما رجعت

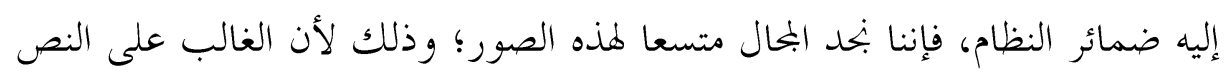


اللغوي - فضلا عن الأدبي - عدم توظيفه نوعا واحدا من الضمائر، وإنما التحول بينها. بيد أننا هنا نورد أمثلة تلتزم بشرطين أساسيين: أن يكون الضمير الأول قد بد بـ ورد أكثر من مرة فشكل نظاما، وأن يكون الضمير الصادع له ذا دلالة فنية. ولعل من أبرز شواهد الشعر الجاهلي التي تتضمن هذين الشرطين قصيدة امرئ

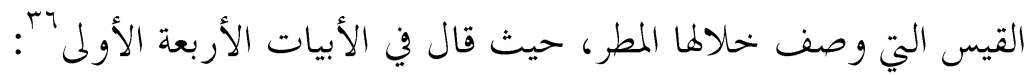

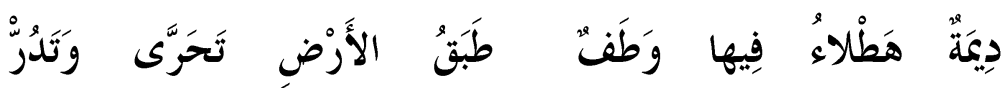
تُخْرِجُ الوَدَّ إذا ما أَثْجَذَذَتْ

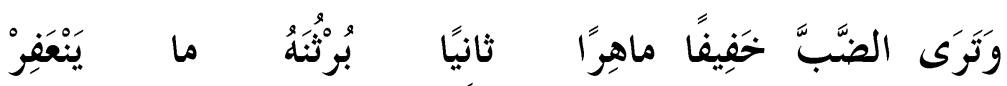

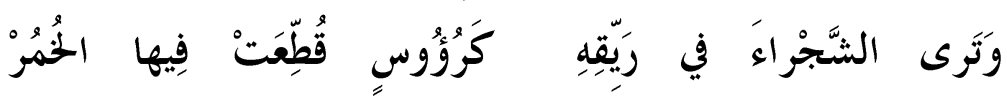
ففي البيتين الأولين يؤسس امرؤ القيس نظاما من ضمائر الغائب المسندة إلى الأفعال

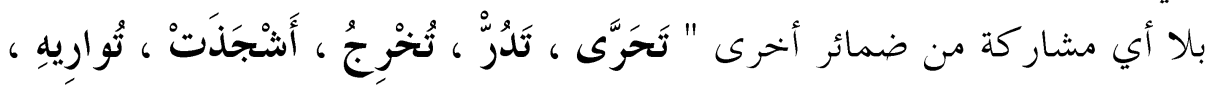

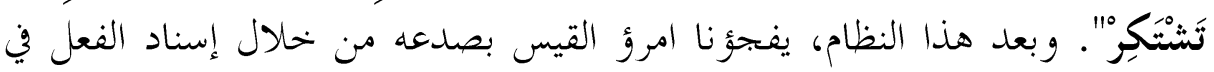

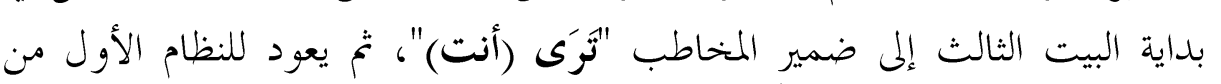

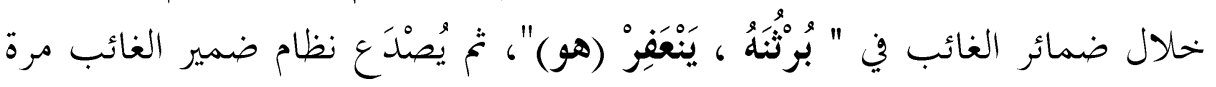

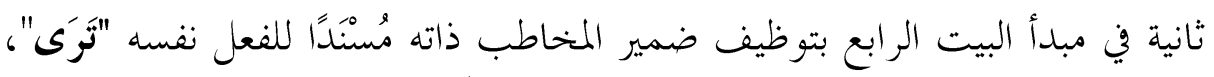

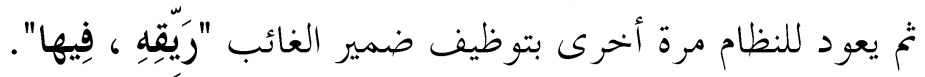

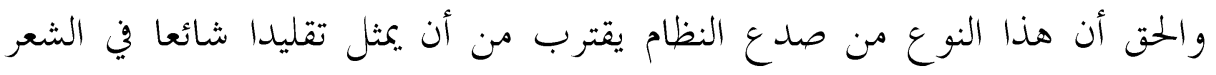

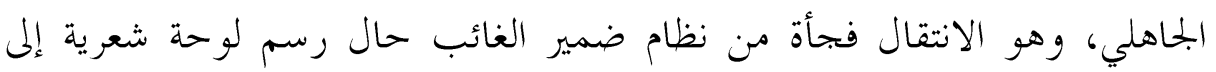

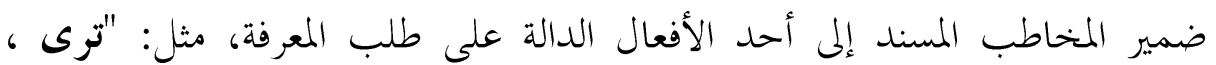

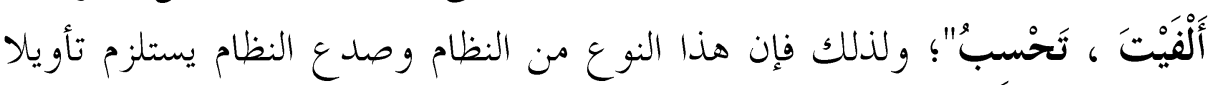

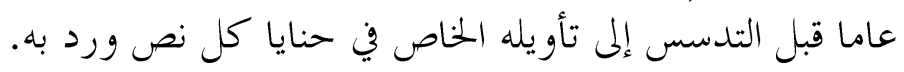

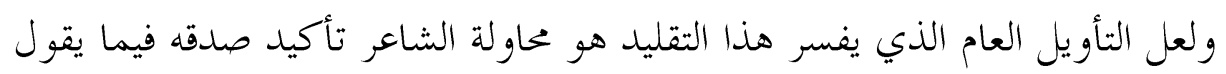

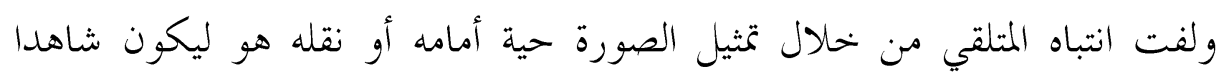

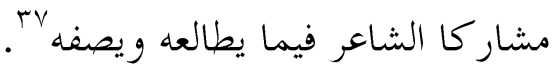


أما تأويل هذا الشاهد خاصة، فإن الشاعر قد عضد نظام ضمائر الغائب من خلال

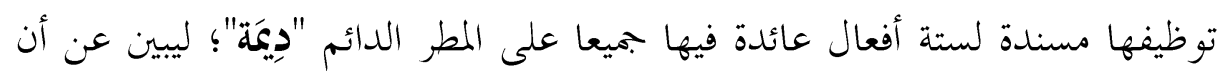
دوام هذه الأمطار قد كفل لها من القوة ما يبعلها فاعلا دائما عبر هذه الأفعال الستة. أما صدع النظام بضمير المخاطب، ثم العودة للنظام، تم صدعه بالضمير ذاته، تم العودة إليه؛ فذلك لأن المخاطب يتجاوز في هذا الموضع صفة المتلقي الذي يرغب الشاعر في مشاركته المشهد إلى المتلقي الذي يمثل عنصرا من عناصر المشهد ليكمل به الشاعر دائرة الوجود. فقد حوت هذه اللوحة عناصر الوجود الثلاثة: الجماد

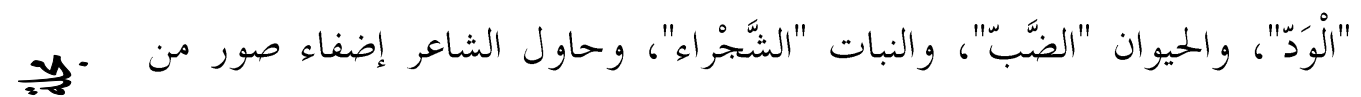
النشوة والحيوية عليها، فكان عليه أن يتم دائرة الوجود بالعنصر الإنساني المتمثل في وانئ

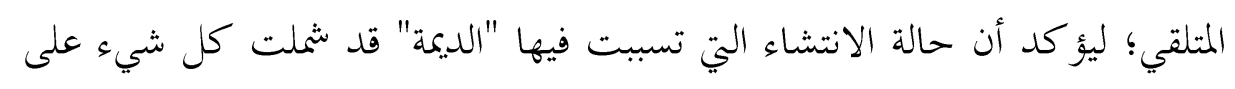
وجه البسيطة أو شنملت الوجود المادي بأكمله. r.

$$
(r-r-r)
$$

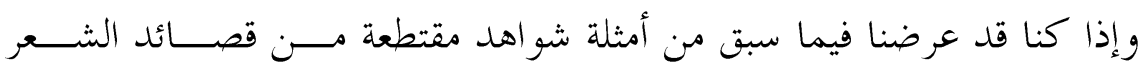

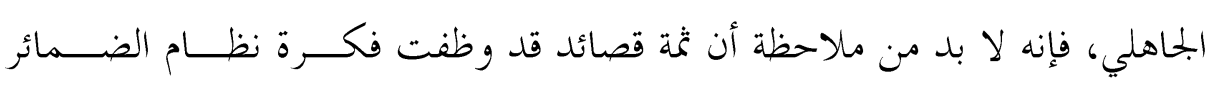

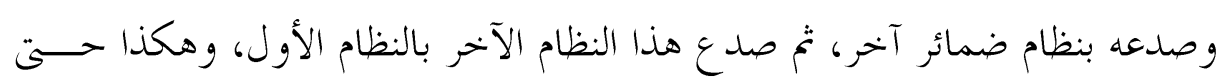
هاية القصيدة.

والحق أن هذا النوع من نظام الضمائر وصدعه على طول القصيدة يفتح بالنسبة لنا بابا من التأويلات؛ ذلك لأن تأسيس النظام وصدعه يتخذ موقفا محسوبا خهـلال القصيدة يغري القارئ بتتبعه و تفكيك بنيته وتحليلها.

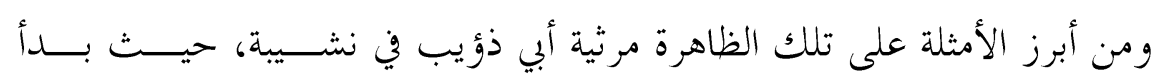

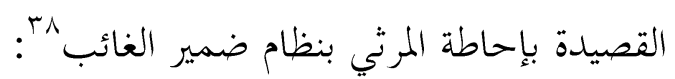

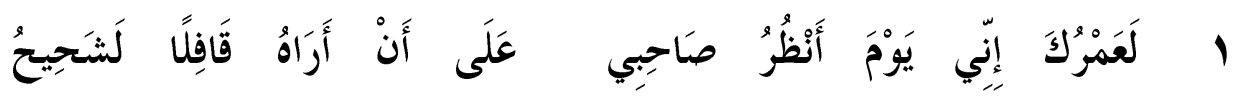

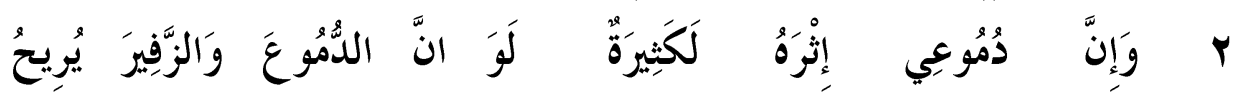




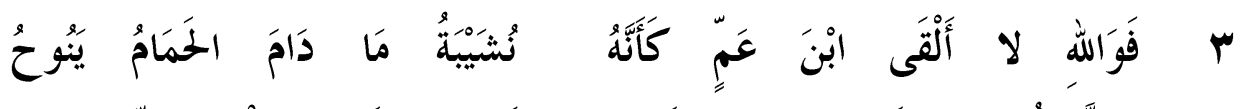

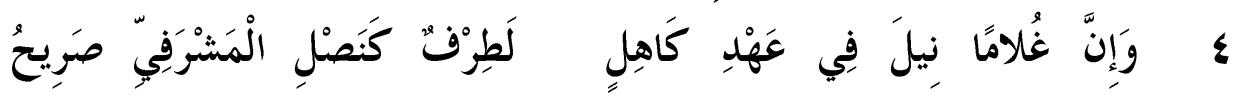

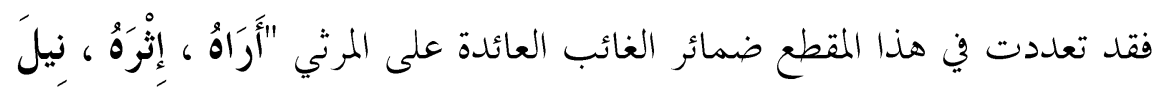

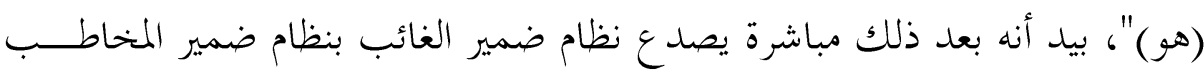
العائد على المرثي أيضا

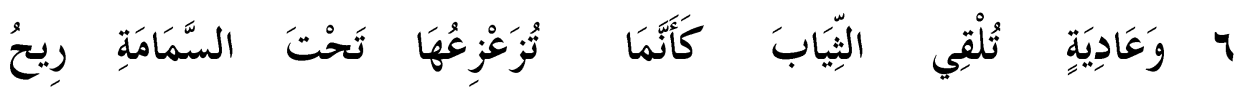

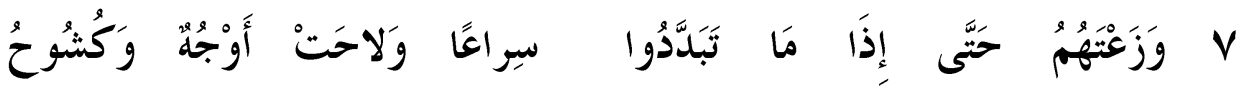

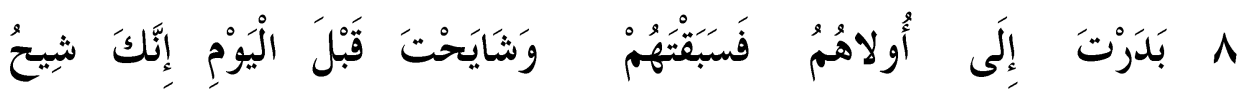

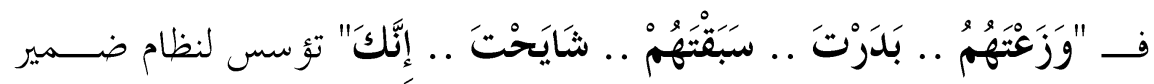

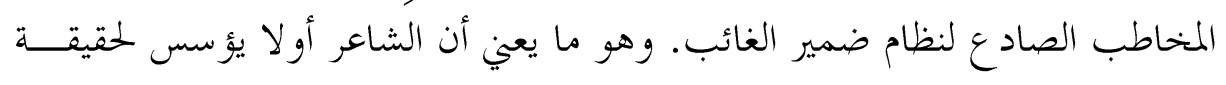

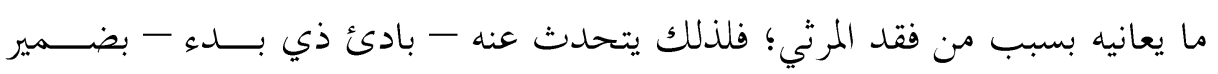

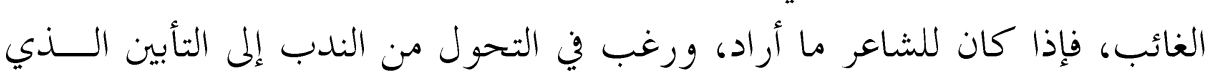

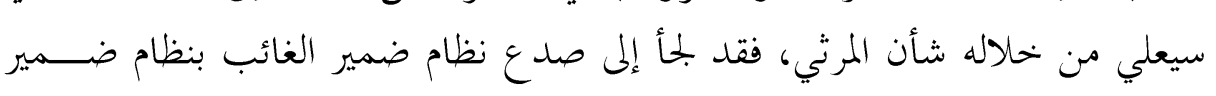

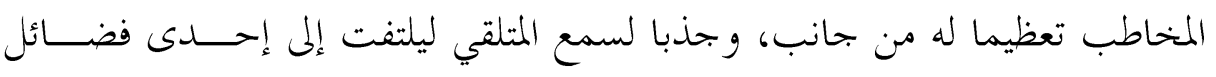

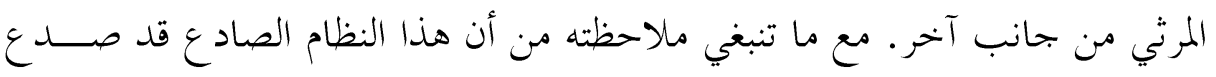
牙 r. $\frac{\overline{3}}{3}$

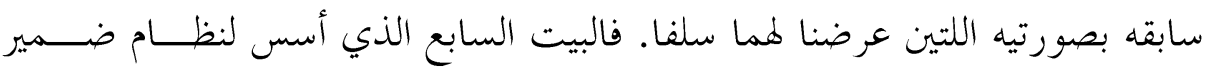

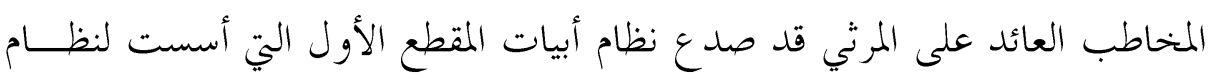

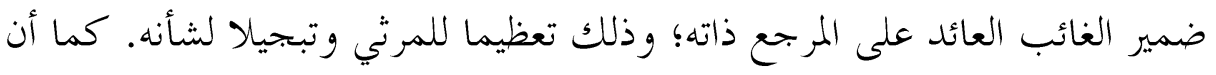

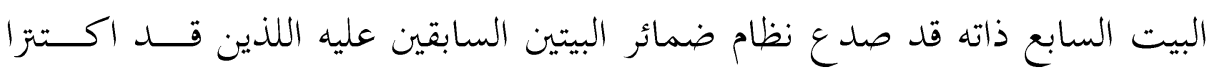

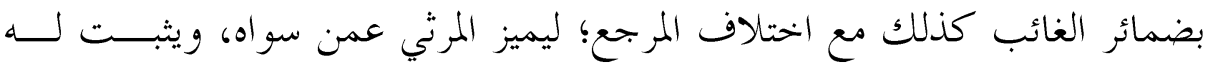
التفرد.

فإذا تم للشاعر مر اده، فإنه يعود ليصدع ع النظام الصادع ســلفا بالنظــام الأول، فيتحول من ضمائر المخاطب إلى الغائب مرة أخرى؛ وذلك ليبقي على حالة إدهاش بر برك

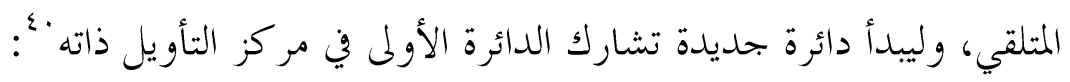




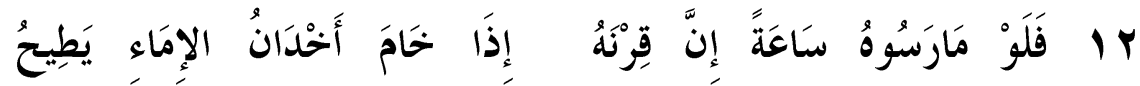
و كأن هذا البيت كان ضروريا في هذا الموضع - على الرغم من قطعه لتـــوالي

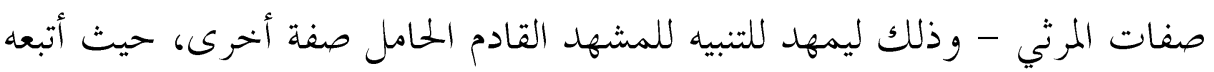
بقوله I": با وَسبرْبِ

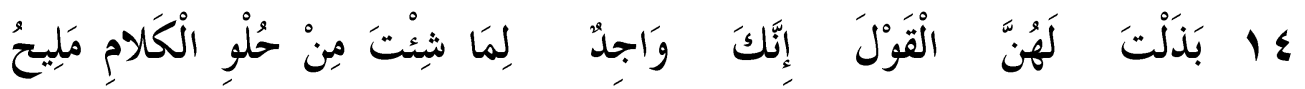
وبذلك نتبين ما أسلفنا ذكره من أننا صرنا أمام دائرة جديدة تتماس مع الدائرة

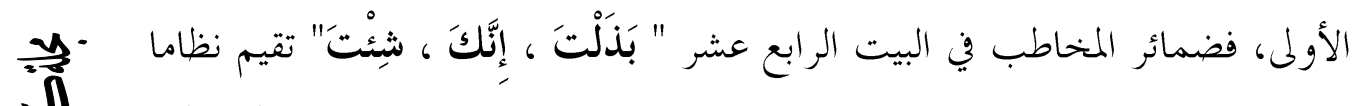

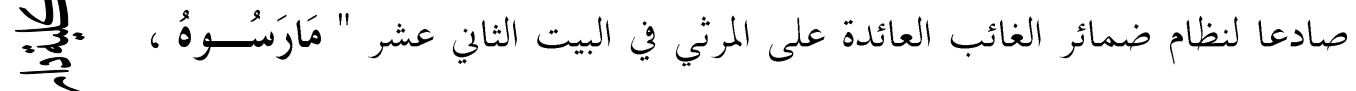

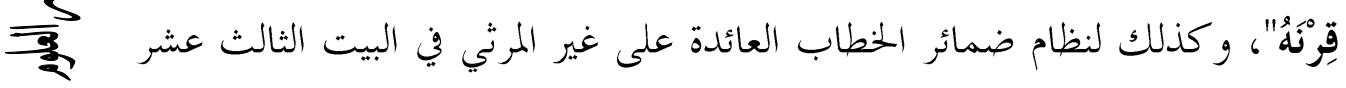

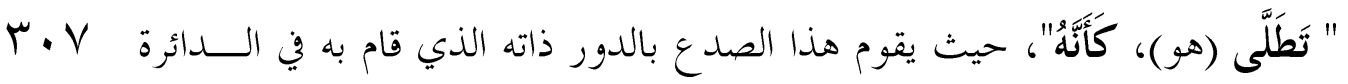

تمخ تبدأ الدائرة الثالثة بنظام ضمائر الغائب العائدة على المرثي أولا، تم على غيره

ثانيا، حتى يأتي نظام صادع لهما من خلال نظام ضمائر المخاطب العائدة على المرثي ثالثا؛ لتتم بذلك الدائرة الثالثة كمثيلتيها السابقتين بأ: 10

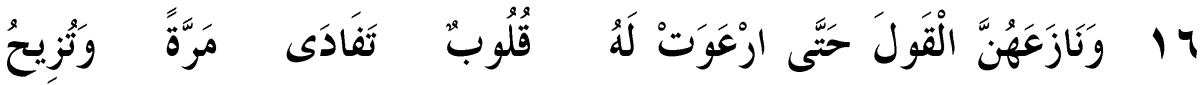

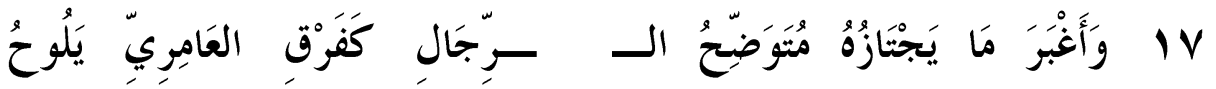

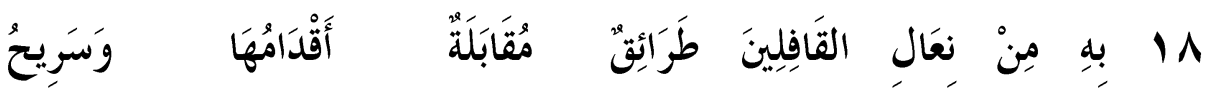

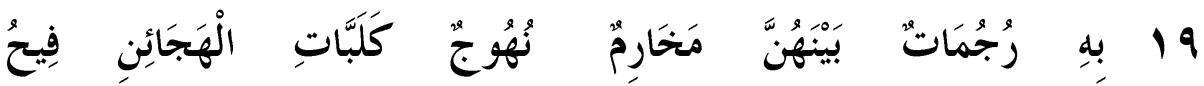

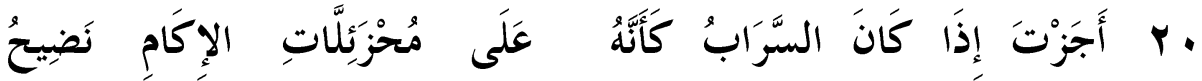

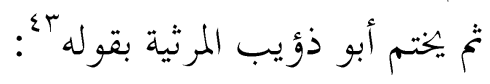




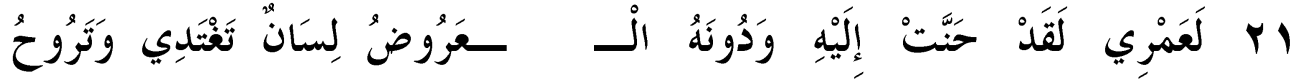

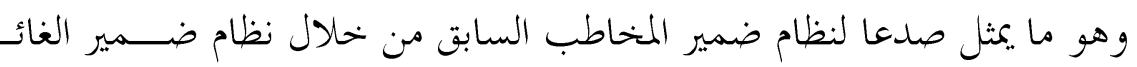

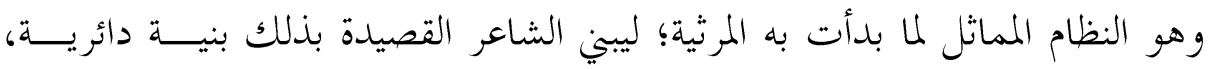

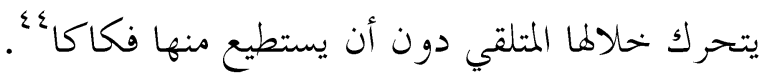

$$
\text { ( } \varepsilon-r-r)
$$

وقد يحدث صدع لنظام الضمائر لا بضمائر مثلها، وإنما بالعودة للاسم الظاهر الذي الذي

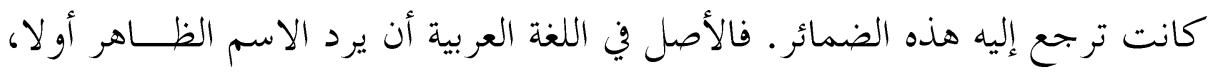

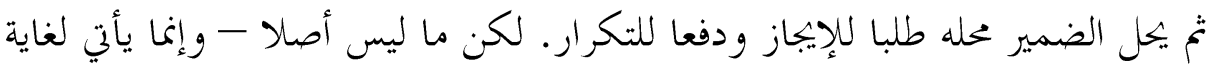

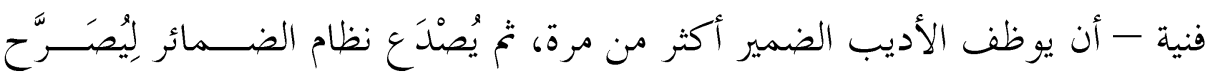
بالاسم الظاهر، سواء كان بدأ به حديثه، أو لم يكن. لون.

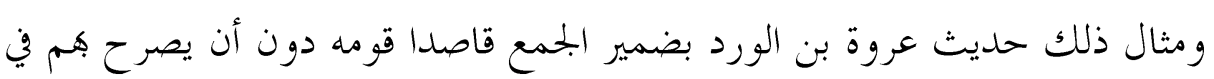

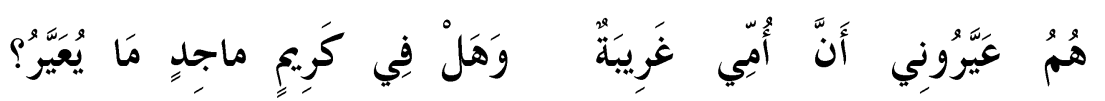

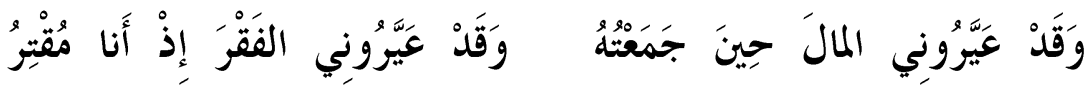

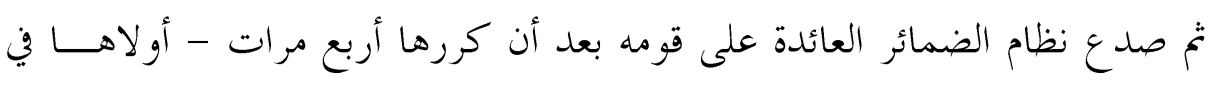

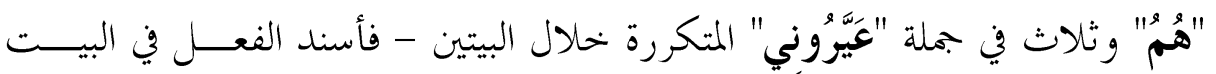

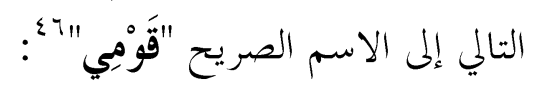

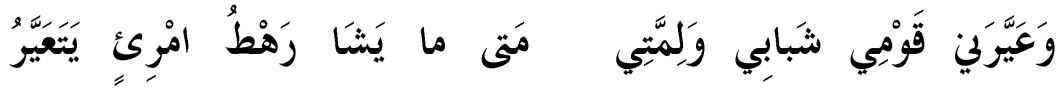

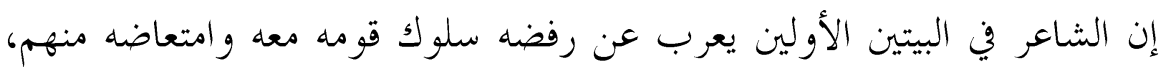

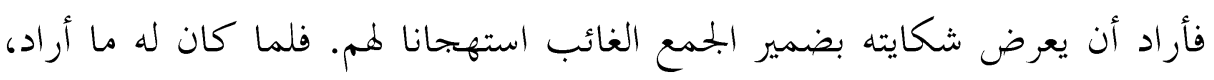

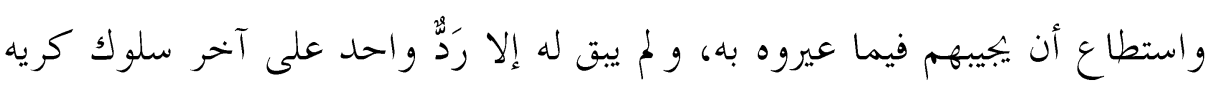

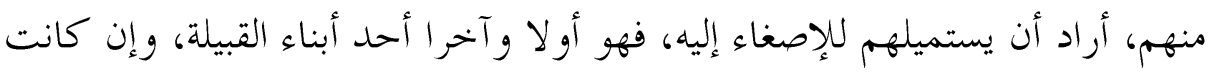

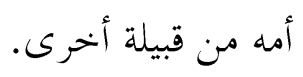




\section{(}

فإذا أردنا أن نصل بالبحث عن ظاهرة النظام وصدع النظام في الأدب الجاهلي إلى الخلفية الموسيقية، فإننا سنولي وجوهنا شطر الإيقاع شعرا ونثرا.

$$
(1-r)
$$

أما إيقاع الشعر، فإن أول عقبة نلفيها حيال تتبع هذه الظاهرة به هو النظام الموسيقي الصارم الذي أحاط القصيدة الجاهلية وزنا وقافية، حيث أدى التزام الشاعر الجاهلي على طول القصيدة بحرا عروضيا واحدا وقافية واحدة إلى إدراج القصيدة في نظام

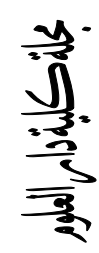

موسيقي شبه صارم لا يتيح للشاعر صدعه من خلال الانتقال من بحر لغيره أو من قافية لغيرها.

ولا يستثنى من ذلك سوى قصائد قليلة صدعت في بعض أبياها نظام البحر العروضي

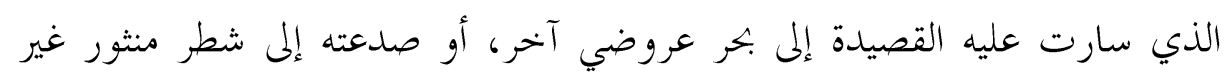
موزون. ومن أبرز هذه القصائد معلقة عبيد بن الأبرص التي تبدأ بقوله: "أََْفَرَ مِنْ

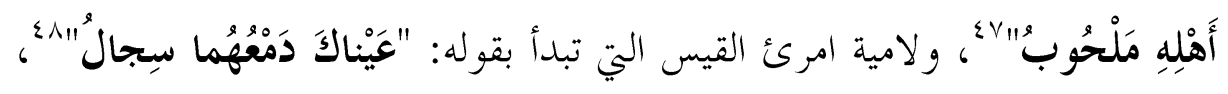

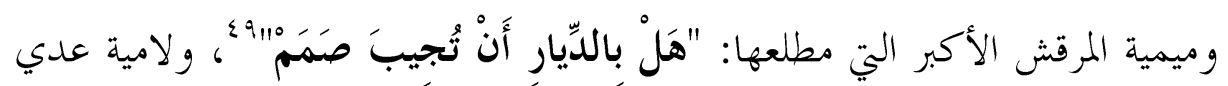

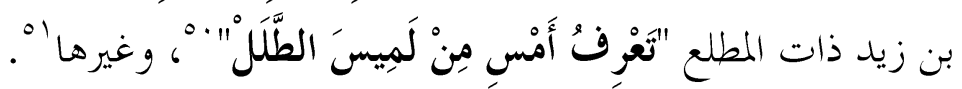
ور.ما كانت أشهر قصائد العصر الجاهلي التي حوت هذه الظاهرة معلقة عبيد بن الأبرص التي ذهب بعض الباحثين إلى اعتبار إيقاعها امتدادا لاضطراب ابت مرحلة نشأنة

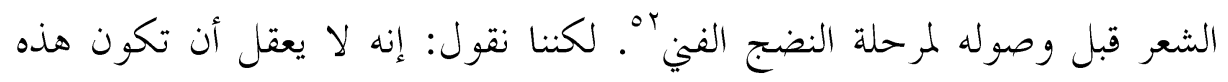

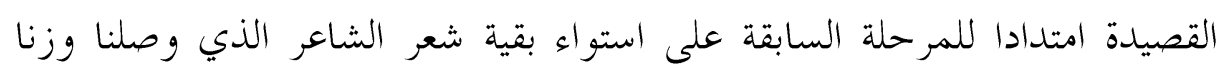
وقافية؛ فلو كان هذا التعليل صحيحا لظهرت له أمارات أخرى في بقية شعره؛

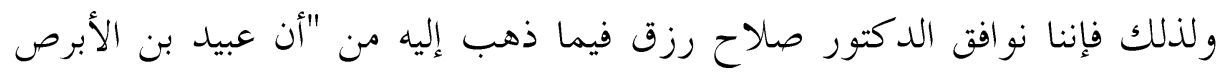

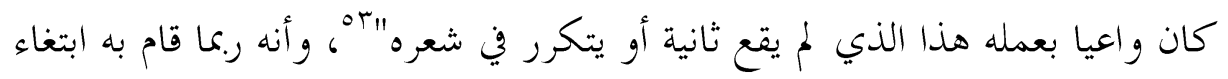

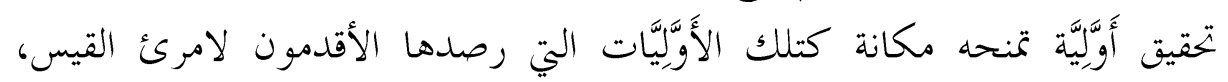

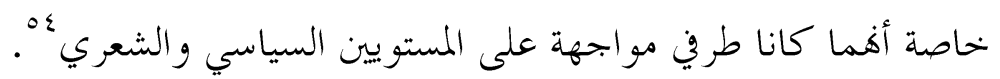


إذن، فثمة افتراض يقول بأن عبيد بن الأبرص قد تعجل الخروج على التقليد

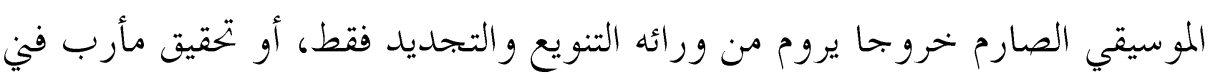
من ورائه.

فإذا طالعنا هذا الافتراض الأخير في ضوء دراسة ظاهرة النظام الإيقاعي وصدعه،

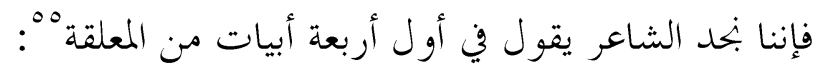

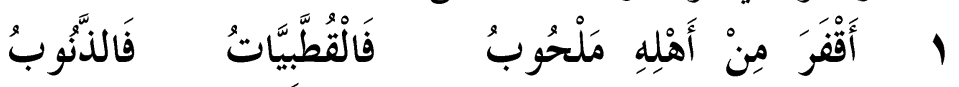

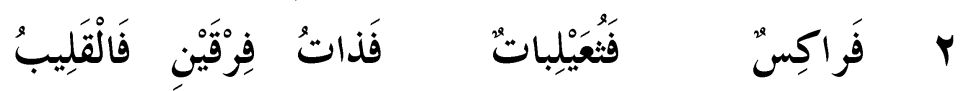

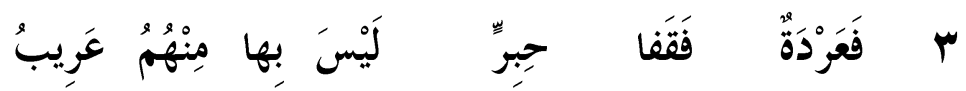

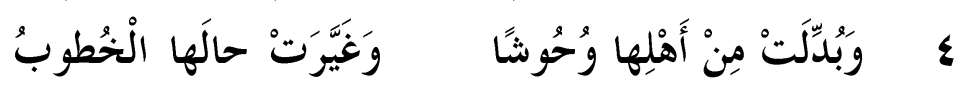

بالتصريع أو بغيره - فإننا نلمح البرف البيت الأول - الذي غالبا ما يجنح الشعر اء إلى تمييزه موسيقيا البسيط

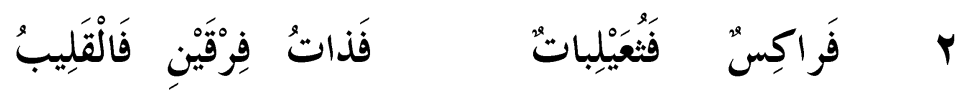

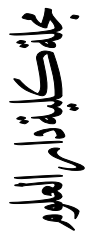

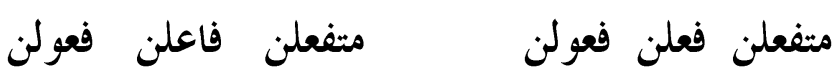

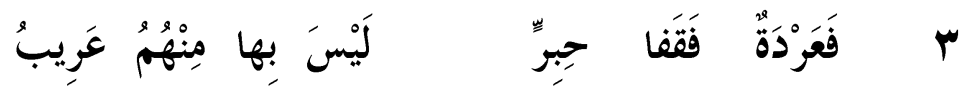

ए.

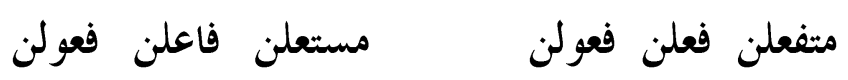

فإذا انتهى الشاعر من تعديد الأماكن التي وقع عليها حكم الإقفار، وأراد أن يصل

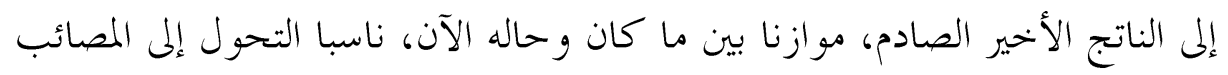
و الأيام، فإنه يصدع النظام في صدر البيت:

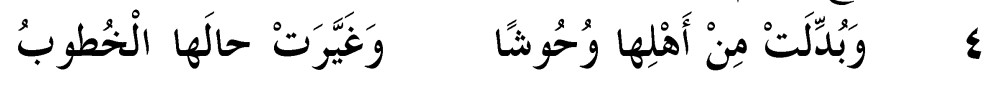
متفعلن مستفعلن فعولن متفعلن فاعلن ـولن

فقد تحولنا من نظام (متفعلن فعلن فعولن) في صدري البيتين السابقين إلى (متفعلن

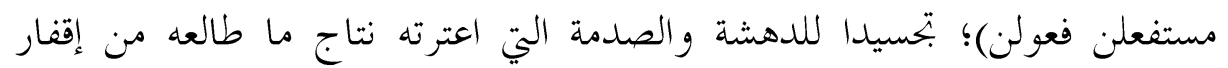

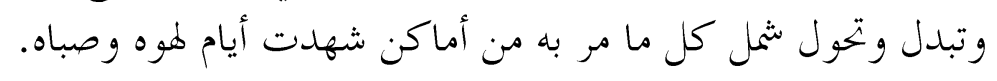


فإذا انتقلنا بعد ذلك إلى الأبيات من السابع إلى الحادي عشر، فإنكك واجدها تسير على نظام مخلع البسيط بتفعيلاته التامة والمزحفة؛ ذلك لأن الأبيات كلها تقدم صورة

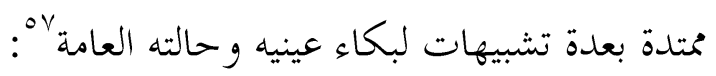

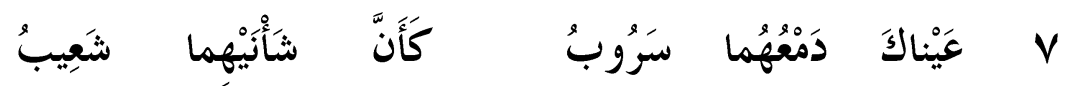

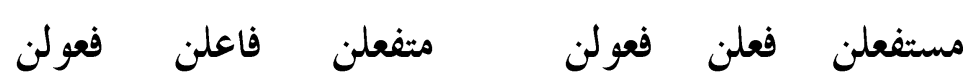

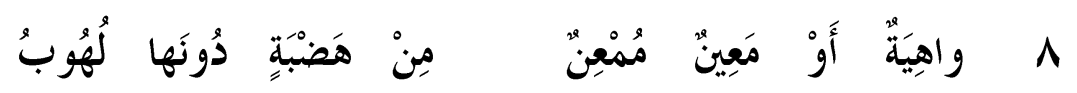

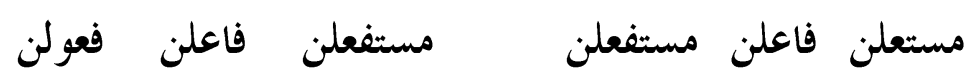

预.

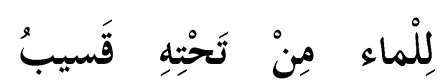
9

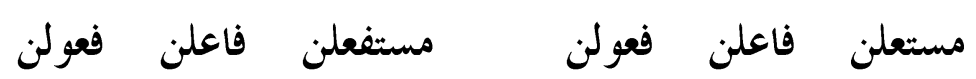

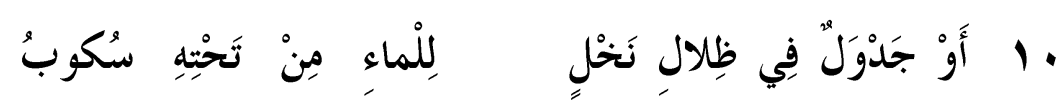
1)

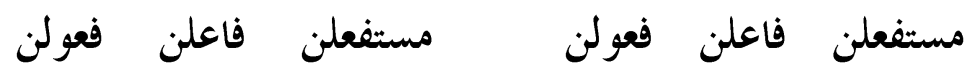
1

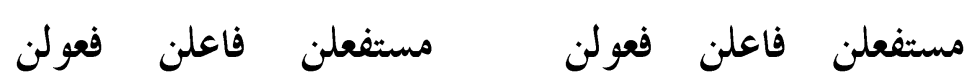
ومع طول مدة السير على هذا النظام، فإن صدعه فجأة يكون أقوى إدهاشا للمتلقي

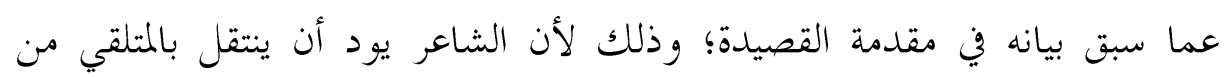

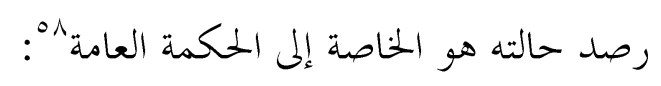

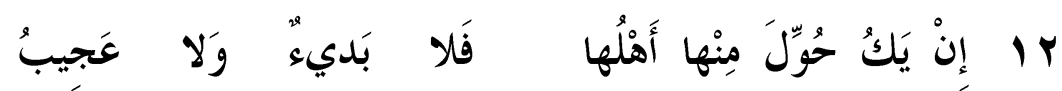

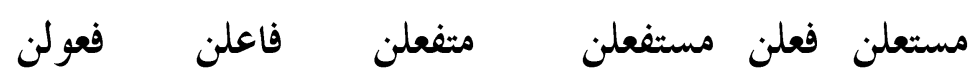

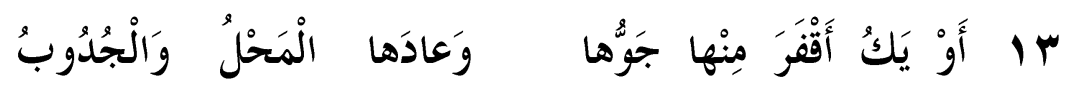

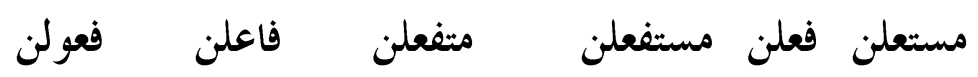

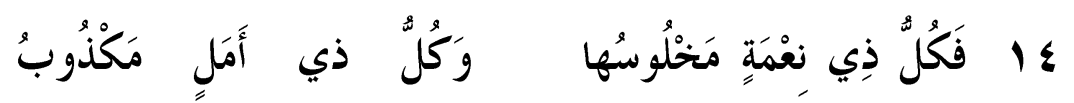

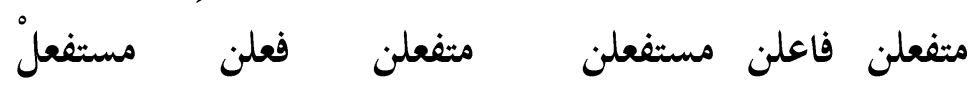


10

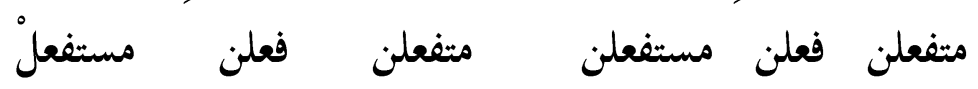

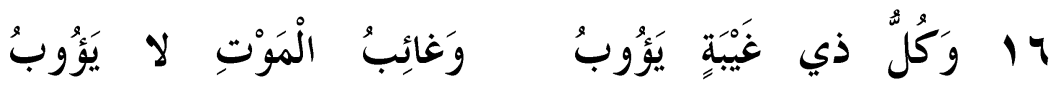

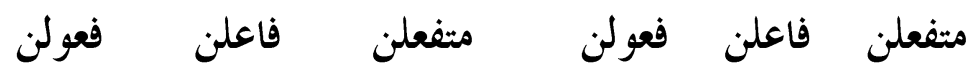
إن الشاعر حينما انتقل إلى الحكمة العامة من خلال التركيب الشرطي، صدع النظام الإيقاعي في صدري البيتين الثاني عشر والثالث عشر، فتحول من (مستفعلن فاعلن فعولن) إلى (مستعلن فعلن مستفعلن)، فلما وصل إلى جواب الشرط والمعطوف عليه وهو ما مثل الحكمة العامة ولب المقصد، فإنه اتسع بصدع النظام ليشمل البيتين الرابع عشر والخامس عشر بصدريهما وعجزيهما، فخرج البيتان بشطريهما عن

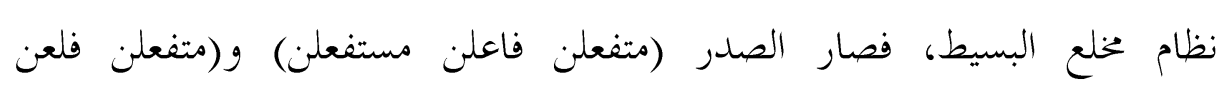

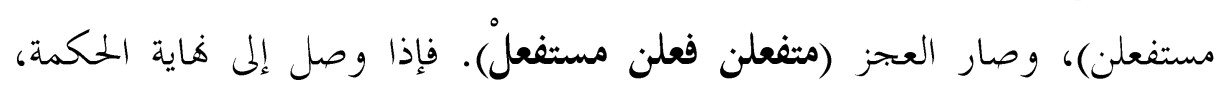
وأراد أن يمهد لمعنى جديد عاد لنظام مخلع البسيط مرة أخرى بالبيت السادس عشر. ومع فاية هذه الحكمة وبدء سيل من الحكم الجديدة، يؤسس الشاعر للنظام الإيقاعي من خلال الحاد البيت السابع عشر مع سابقه السادس عشر في قالب مخلع البسيط

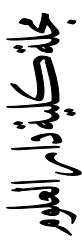
r $\frac{\overline{3}}{3}$

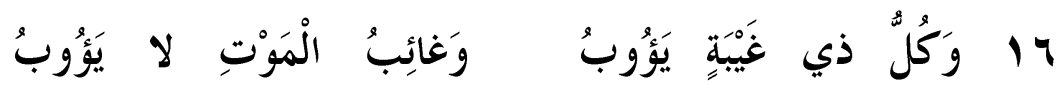

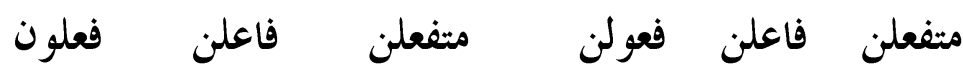

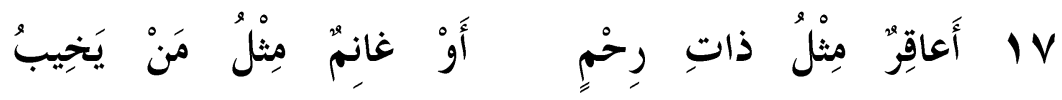

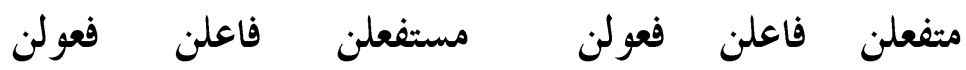
وبعد هذا النظام، يبدأ الشاعر حكمته التالية بصدع له، بيد أن هذا الصدع هو الوحيد في القصيدة كلها الذي صدع النظام بنظام موسيقي لبحر آخر، حيث خرج

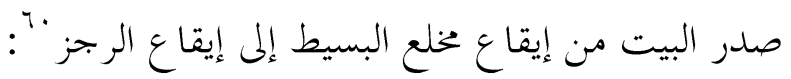


1

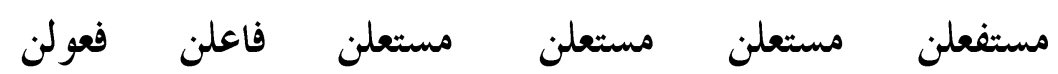
وذلك لما لهذا البيت من خصوصية، فهو أول بيت بالقصيدة يوجه فيه الثاعر حديثه للمتلقي مخاطبا إياه و ناصحا له. و بعد هذا ينقلب الأمر في هذه القصيدة، حيث يصبح النظام على غير مخلع البسيط،

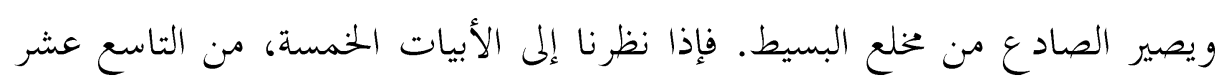
إلى الثالث و العشرين

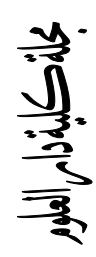

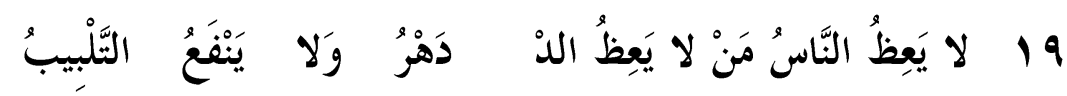

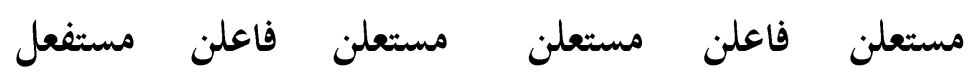

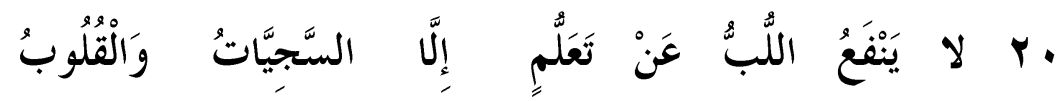
MT

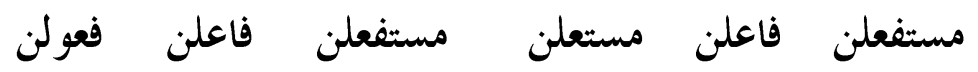

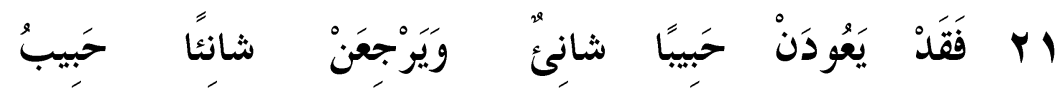

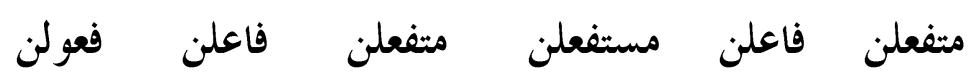

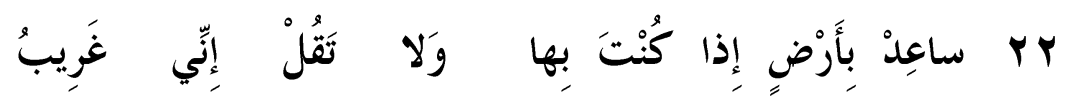

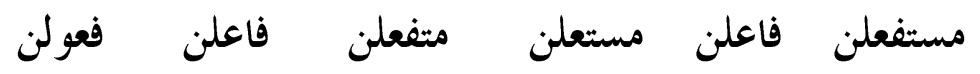

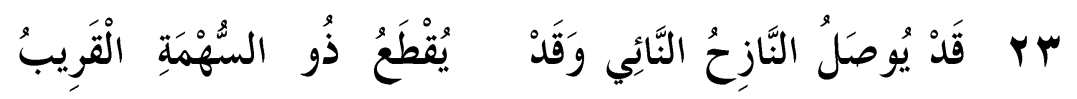

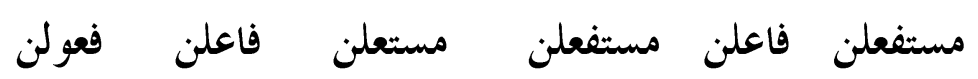
فإننا بند أن صدور هذه الأبيات الخمسة خحارجة عن مخلع البسيط إلى (مستفعلن فاعلن مستفعلن) بزحافاها. فإذا ما انتقل الشاعر من هذه الحلكم التي تمثل فلسفة إلنات وجودية فيزيقية إلى حكم أخرى تمثل فلسفة وجودية غيبية تتعلق بالإيمان بالله، فإنه

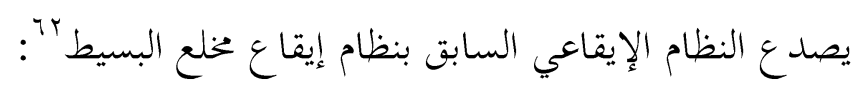

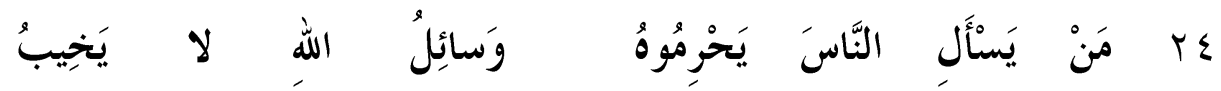




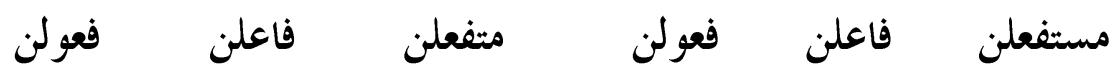
وهكذا تستطيع أن تتبع هذه الظاهرة خلال معلقة عبيد التي تعد من أبرز قصائد الجاهلية التي صدعت إيقاع الأبحر العروضية بالخروج عنها إلى إيقاعات أخرى.

$$
(r-r)
$$

و كذلك فإن نظام الإيقاع في الشعر العربي كان صارما فيما يتعلق .معظم مظاهر

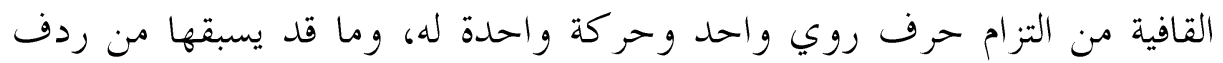
و تأسيس.

وقد نظر علماء العربية القدامي - وتبعهم معظم المحدثين - إلى أن الخروج عن هذا

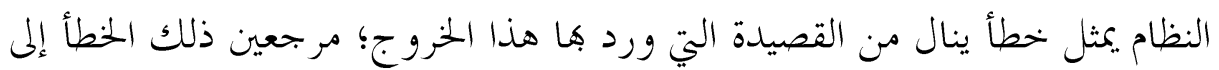

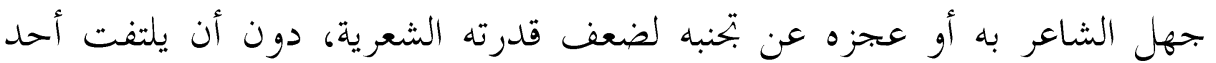

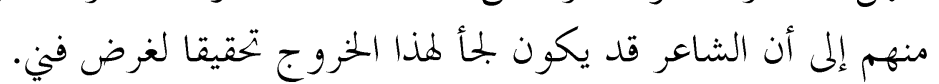

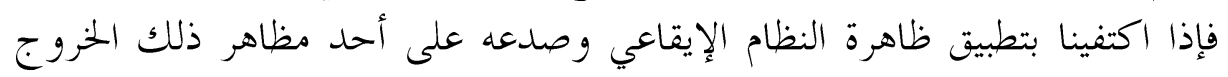

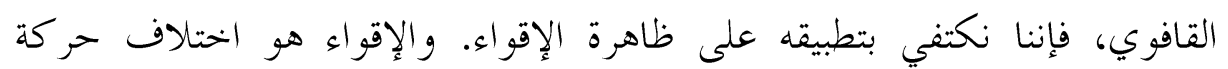

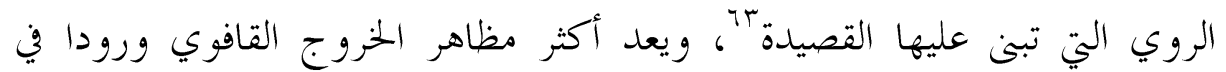
$\frac{\sqrt{3}}{3}$

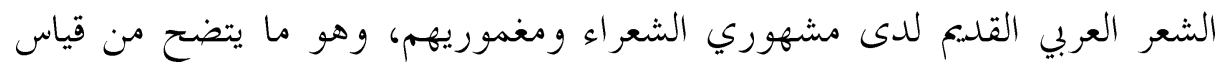

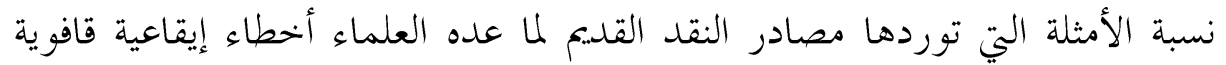

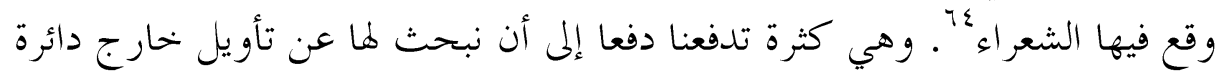
ए

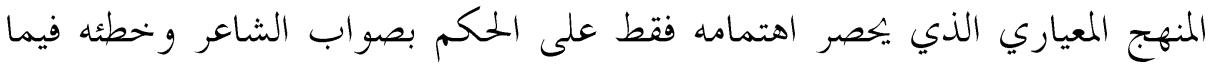
أتى به. وقد كان من الأمثلة التي أوردها العلماء قديما لظاهرة الإقواء قول دريد بن الصمة

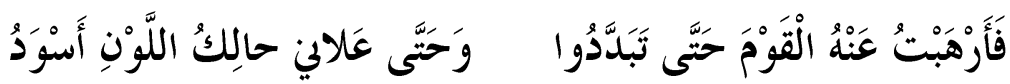

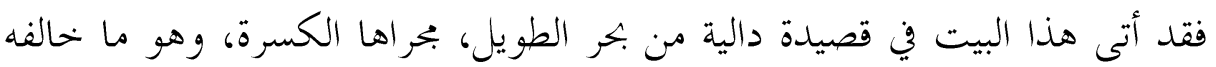

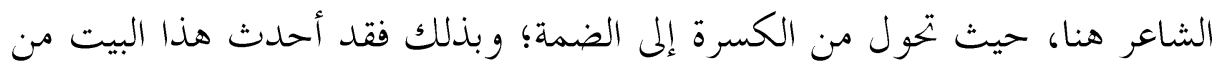

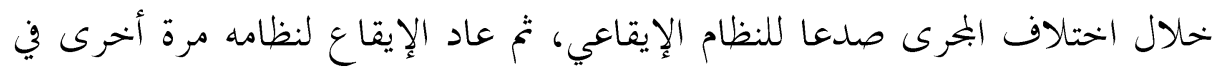

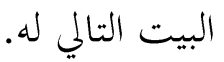


ولتحليل الأثر الفني هذا المظهر من مظاهر صدع النظام الإيقاعي، فإننا لا بد أن نعلم

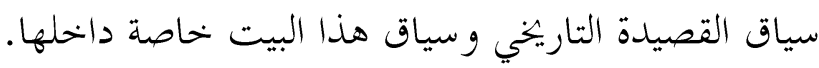

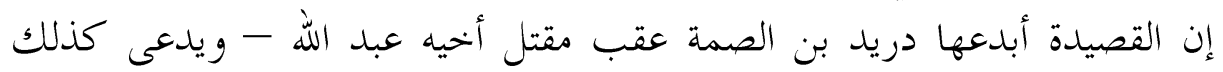

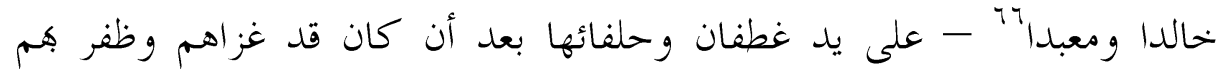

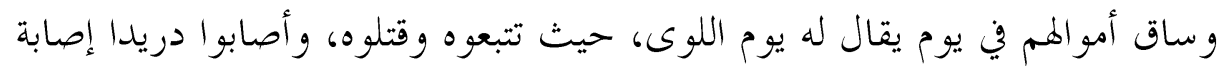

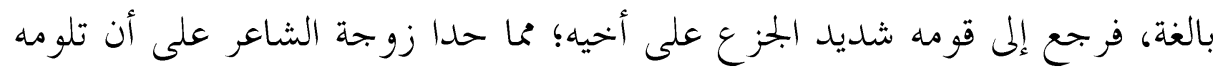

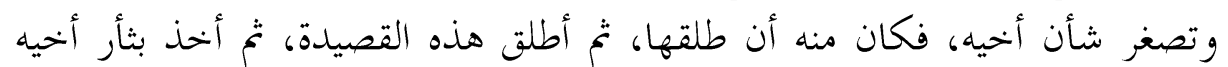

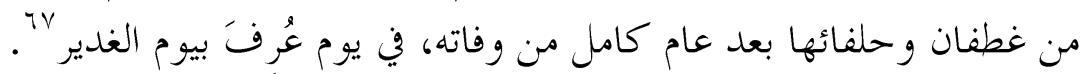

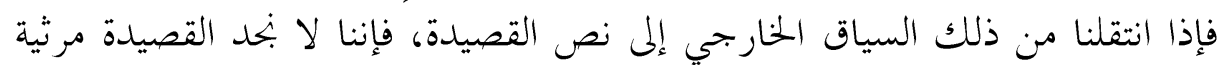

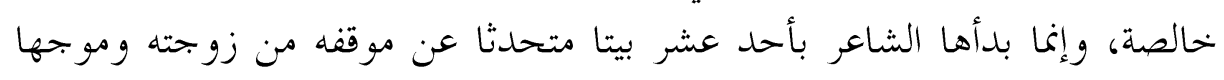

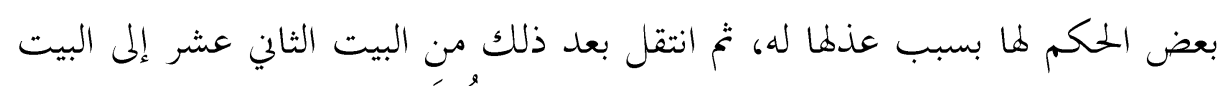

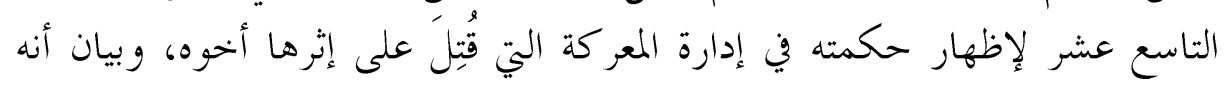

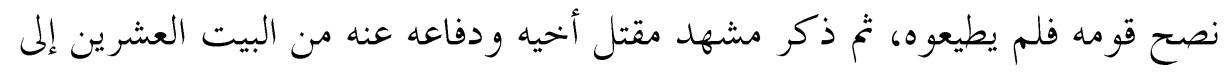

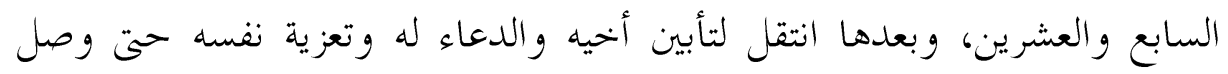

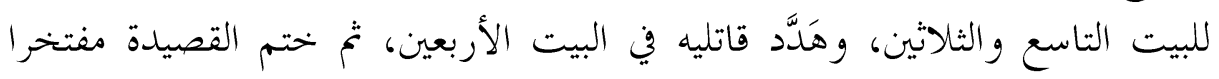
بفروسيته هو واصفا فرسه من البيت الحادي والأربعين إلى السادس والئ والأربعين.

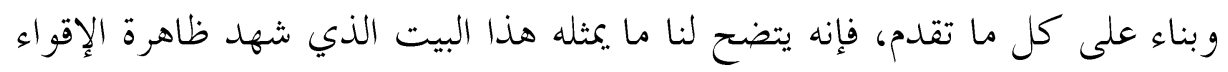
من أهمية؛ حتى إن الشاعر أقام خلاله - بمساعدة الإقواء - تصريعا داخل القصيدة

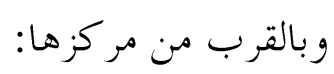

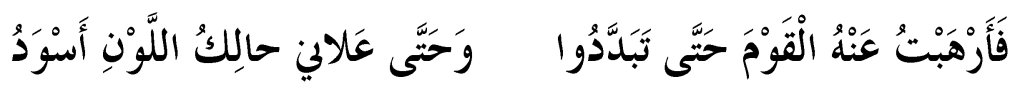

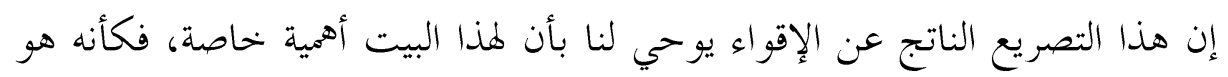

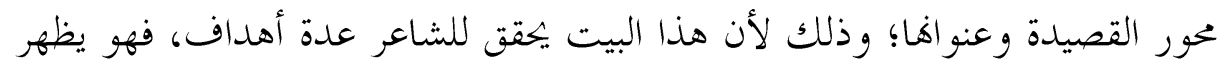

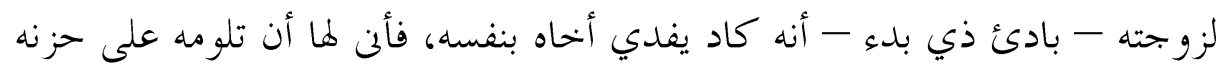

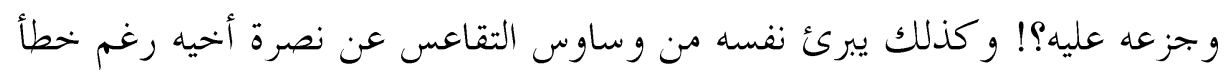

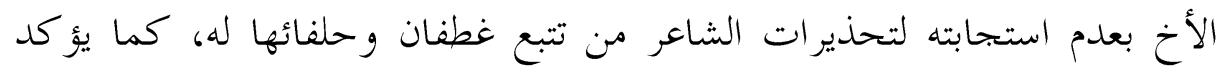

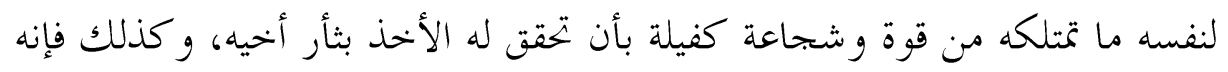
يبعث برسالة تديد ووعيد لقاتلي قومه. 
وبذلك فإن هذا البيت يغذي ويرفد كل جزئيات القصيدة ومعانيها من مبدئها إلى

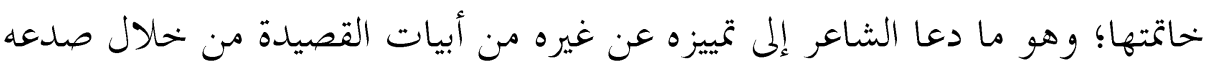
النظام الإيقاعي، وتحقيقه تصريعا خاصا بالقرب من مركز القصيدة، فهذا هو البيت

$$
\text { الخامس والعشرون من بحمو ع أبيات القصيدة البالغ ستة وأربعين. }
$$

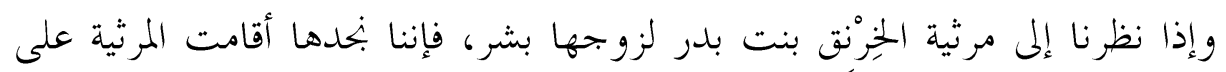

$$
\text { روي القاف المكسورة }
$$

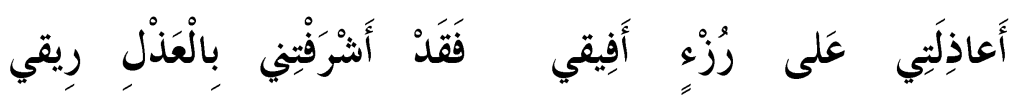

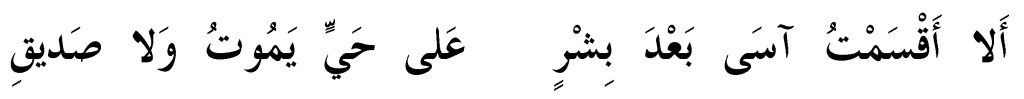

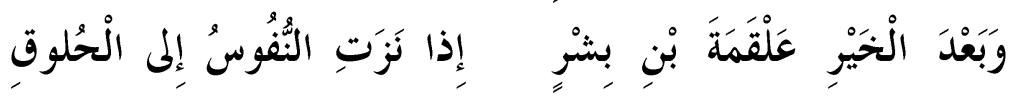

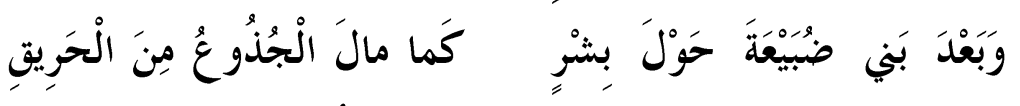

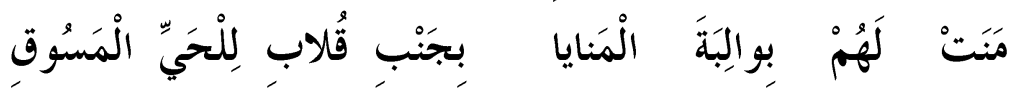

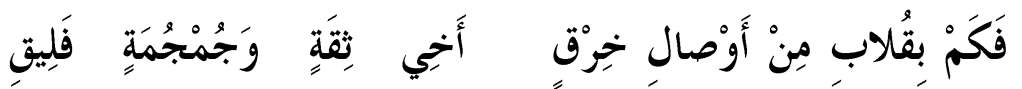

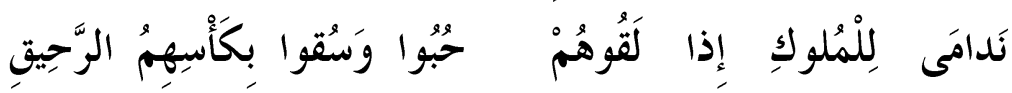

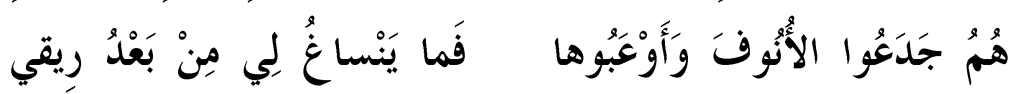

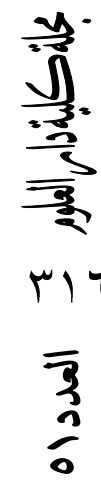

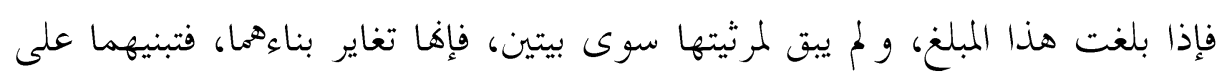

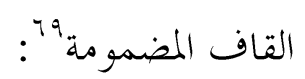

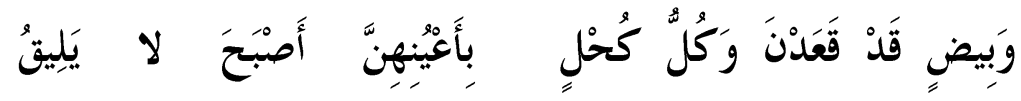

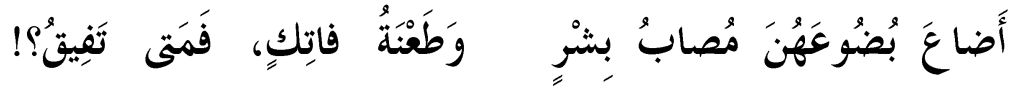
إن الشاعرة حينما رامت الانتقال من الحلديث عن الماضي إلى توصيف الواقع الأليم

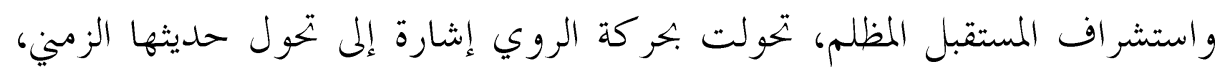

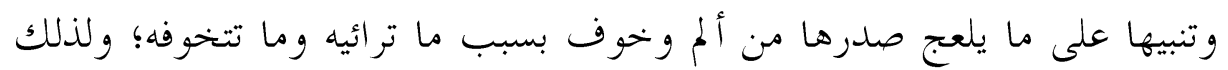

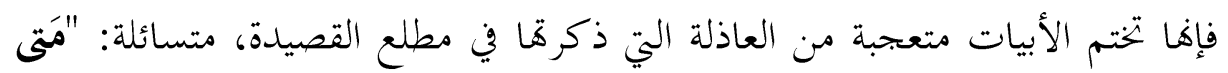

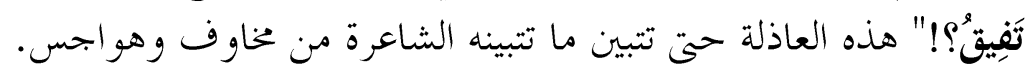




$$
(r-r)
$$

فإن كان من متنفس للشاعر يتيح له أن يصدع النظام الإيقاعي دون خروج عن

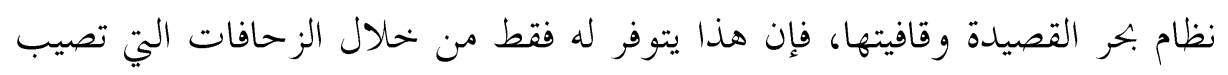

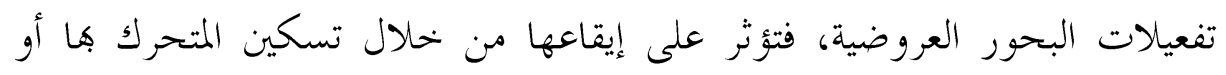
حذف الساكن. وبذلك فإننا قد نلفي أنفسنا أمام صورتين من النظام الإيقاعي وصدعه، فقد يشكل تكرار التفعيلات التامة في صدور الأبيات أو أعجازها نظاما تم

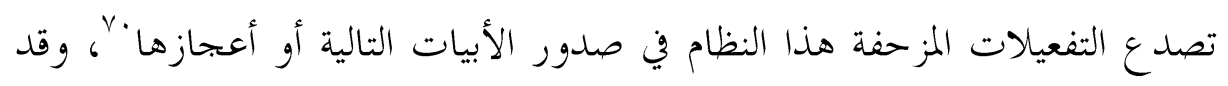

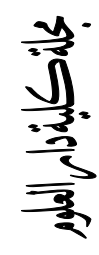
تشكل التفعيلات المزحفة من خلال تكرارها في صدور الأبيات أو أعجازها نظاما تم تصدع التفعيلات التامة هذا النظام في صدور الأبيات التالية أو أعجازها. فني ختام معلقة النابغة الذبياني، بخده يقول

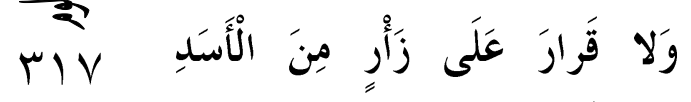

$\overline{3}$

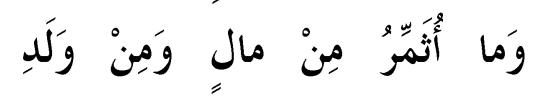

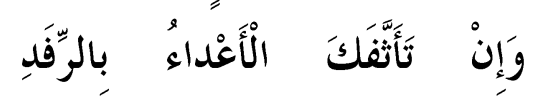

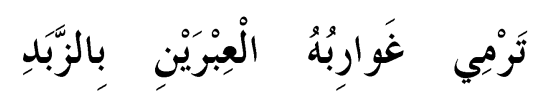
فِيبِ رُكامُ مِنَ الْيَبْوَتِ وَالْخَضَدِ

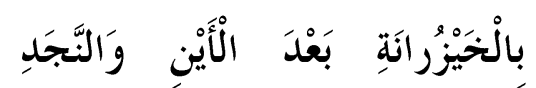

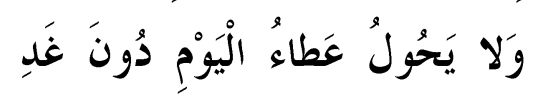

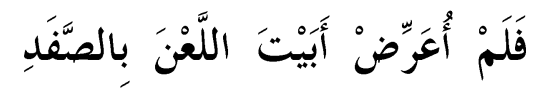

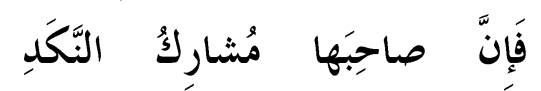
أُنْبُئتُ

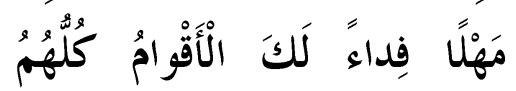

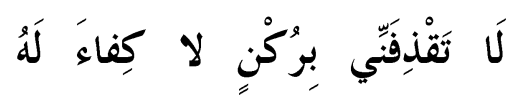

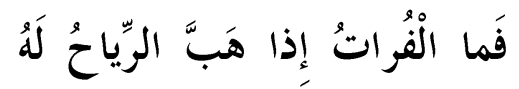

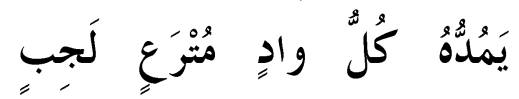

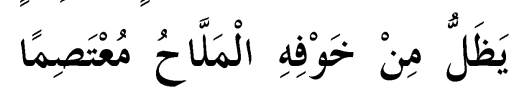

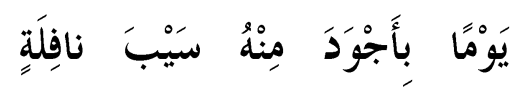

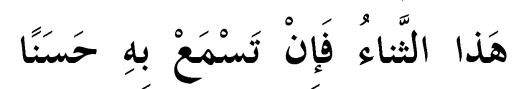

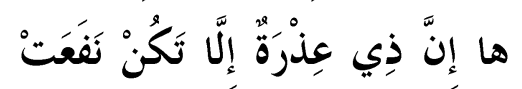
فالشاعر يبدأ كل بيت من الأبيات الثلاثة الأولى بتفعيلة (مستفعلن) تامة؛ لتناسب

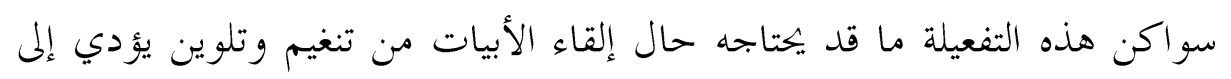
التأكيد على مطلبه من خلال الضغط على هذه السواكن، خاصة في البيتين الثاني 
والثالث. فإذا شرع في رسم صورة ممتدة من خلال التركيب "ما ... بـــ..."، فإنه يلجأ إلى توظيف التفعيلة المخبونة (متفعلن) عبر الأبيات الثلاثة التالية ليوالي بين

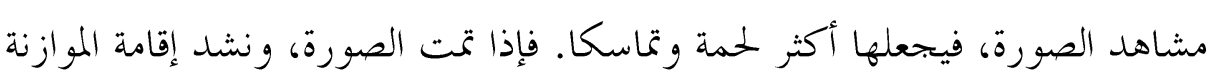
بينها وبين الممدوح، فإنه يعود إلى توظيف التفعيلة التامة مرة أخرى (مستفعلن)

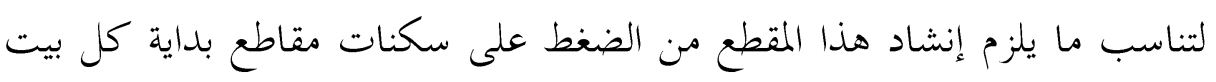
نشدانا للإبطاء الممهرد لختام القصيدة.

وفي إحدى قصائد الأعشى الغزلية، نلفيه يقيم نظاما إيقاعيا في بداية ثلاثة أبيات

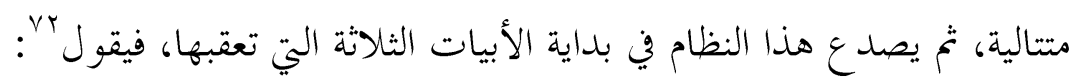

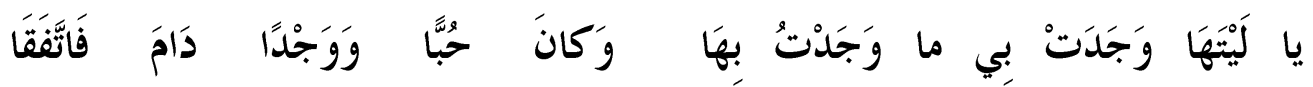

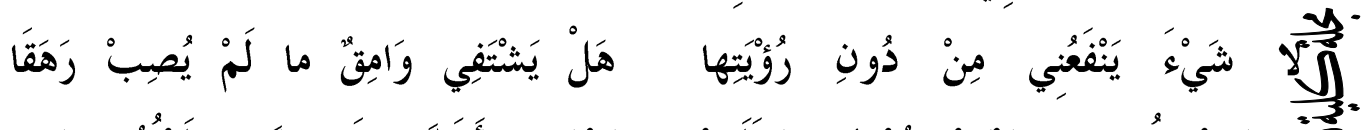

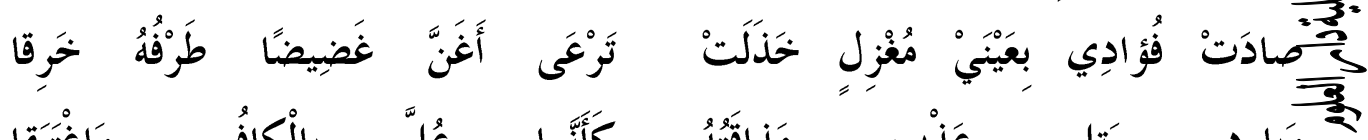

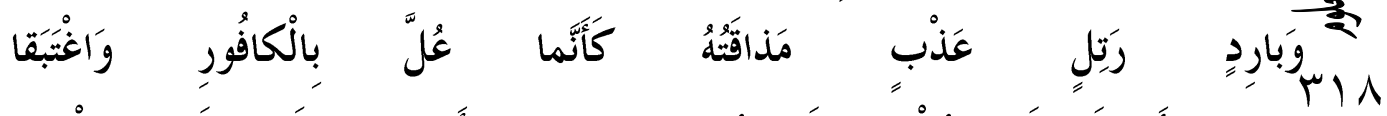

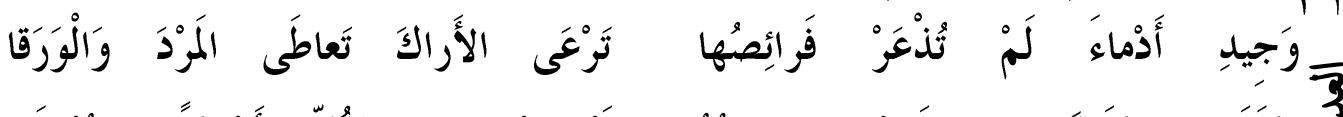

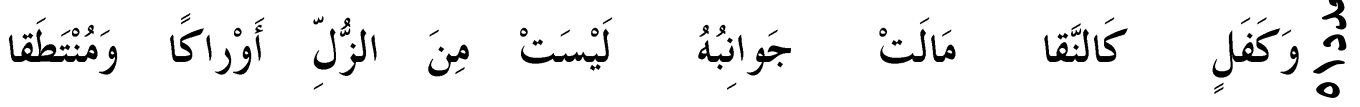

إن الأعشى في أول ثلاثة أبيات يبتدئ كلا منها بالتفعيلة التامة (مستفعلن)، وهي

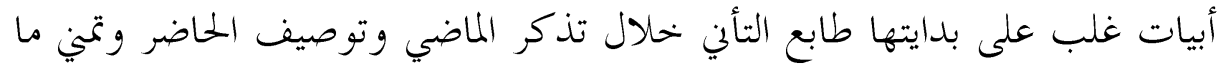

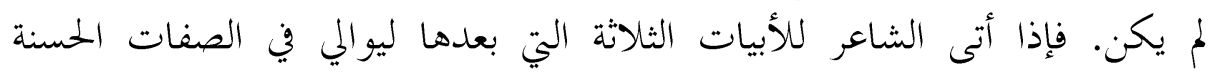

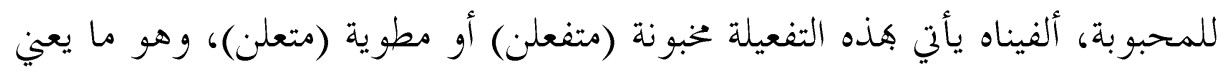

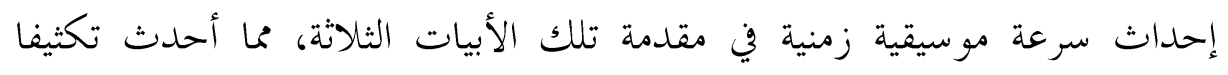

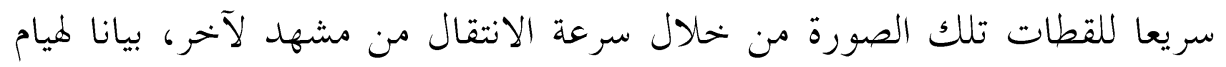
الشاعر هذذه المشاهد وتو المي صورها أمام عينيه.

$$
(\varepsilon-r)
$$

أما في النثر الجاهلي، فإن المعلوم أن خواتيم الجمل تسير على أحد نظامين، هما:

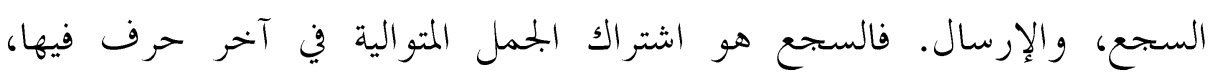


والإرسال خلاف السجع، أي أن تختص كل جملة بخاتمة خلاف الجملتين السابقة

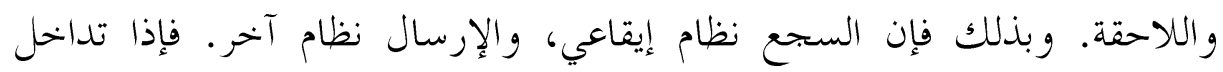

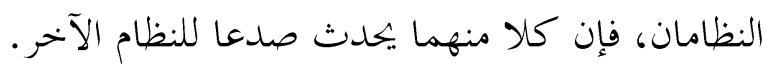

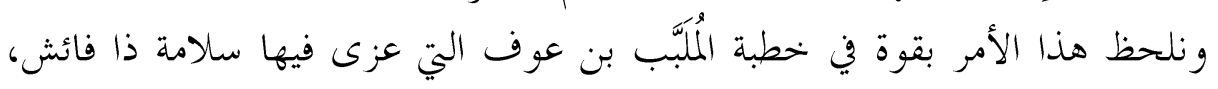
حين قال

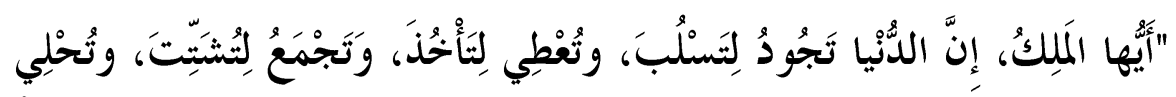

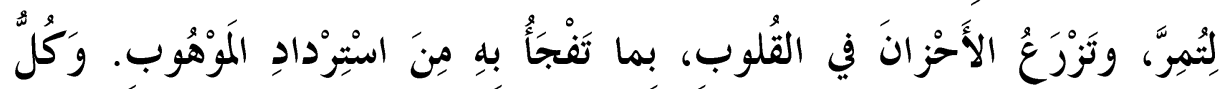

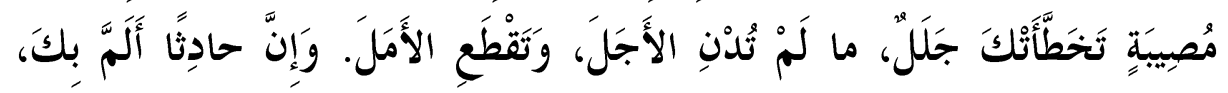

弯. ए19

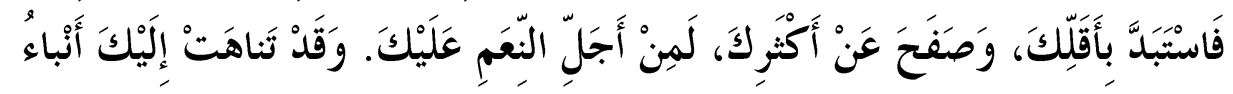

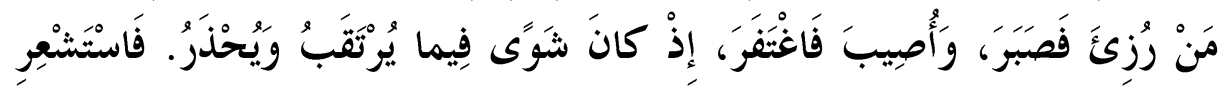

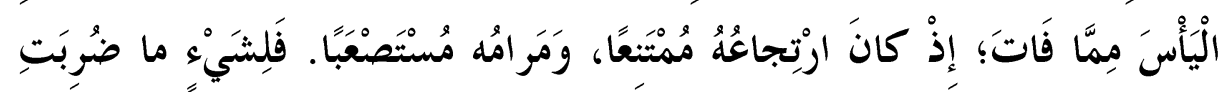

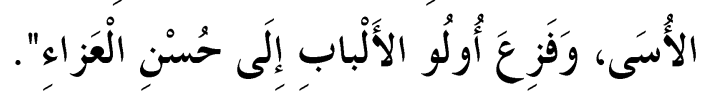

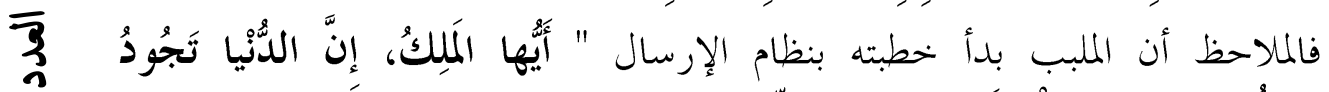

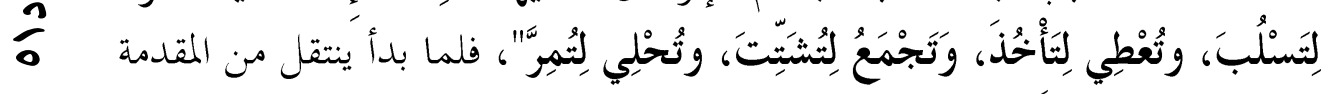

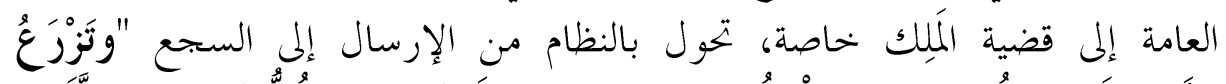

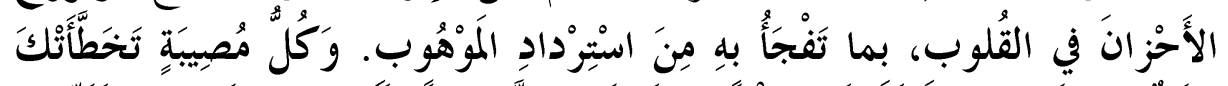

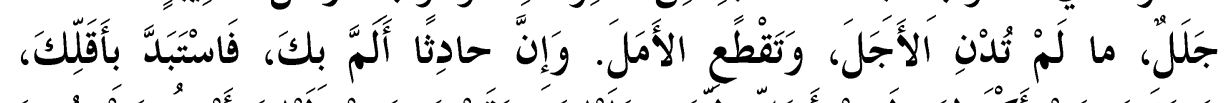

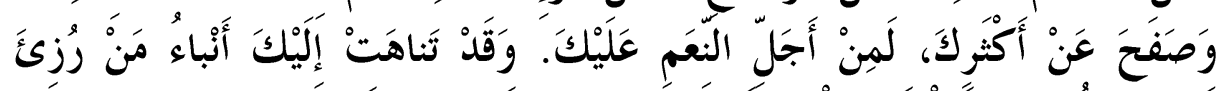

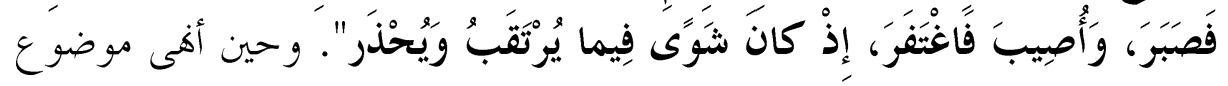

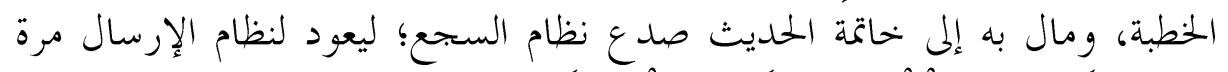

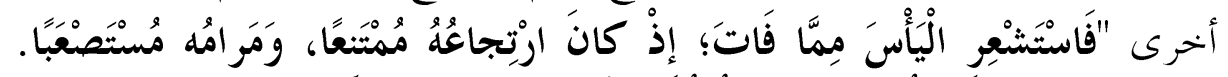

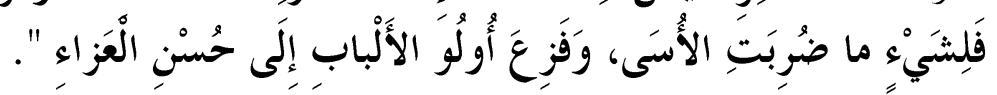

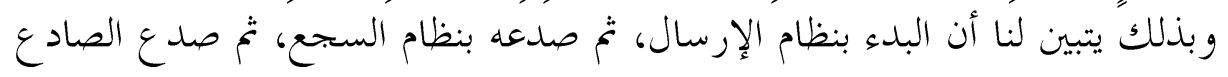

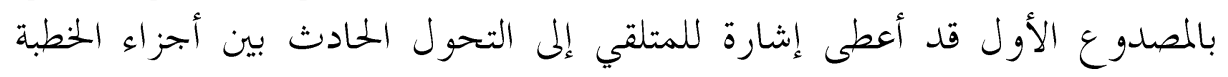

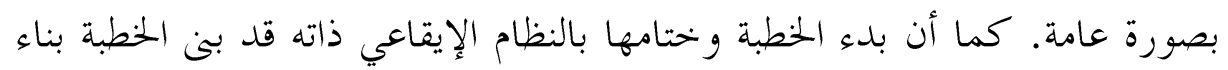

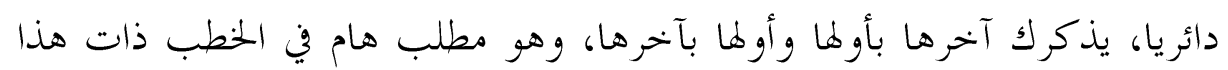




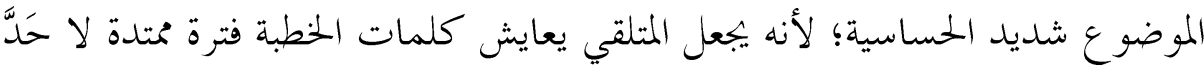

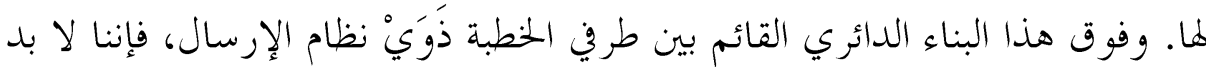

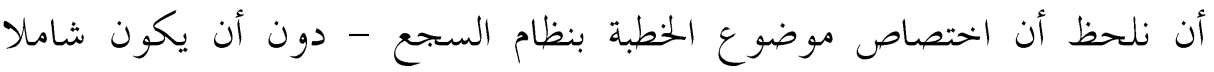

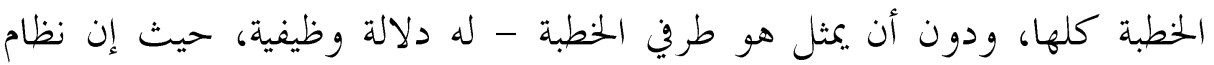

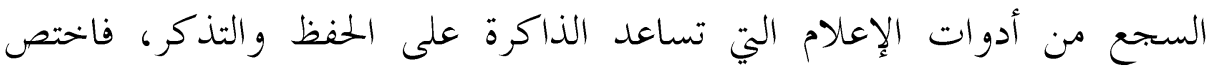

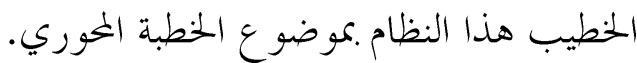

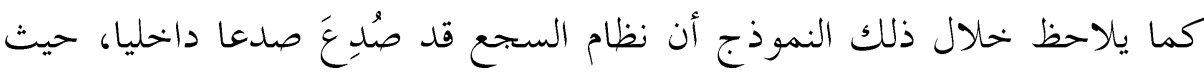

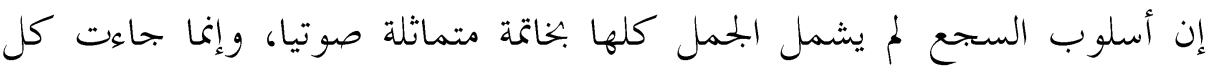
جملتين أو ثالاث بخاتمة متماثلة فيما بينها، مخالفة للخاتمة التي قبلها أو بعدها. فقد قام

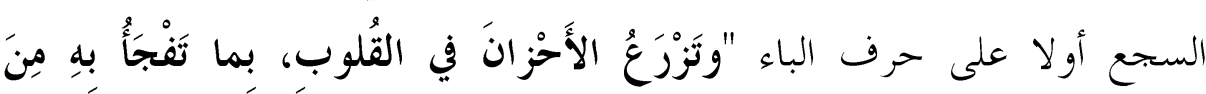

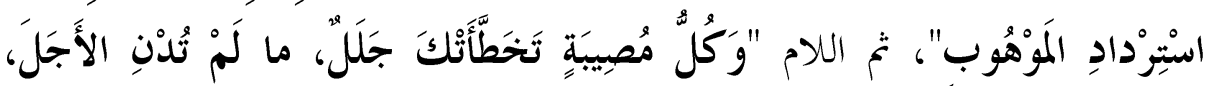

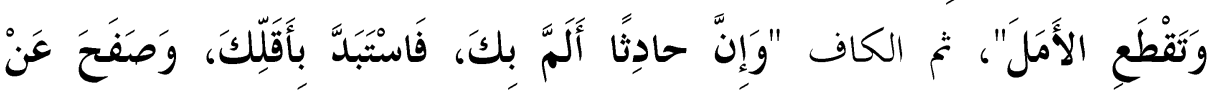

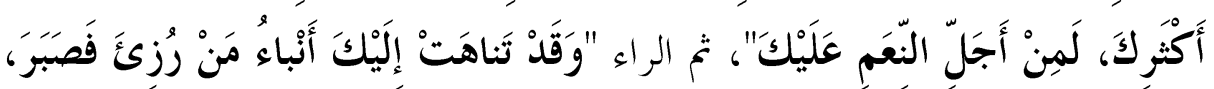

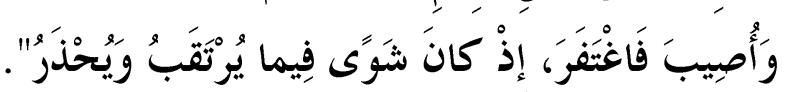

ور.ما كان صدع نظام السجع داخليا - عبر تنويع الخواتيم المتماثلة للجمل

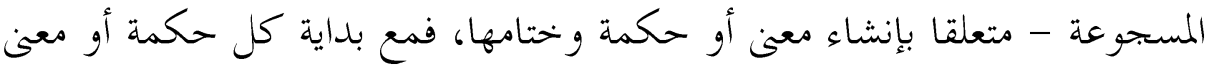

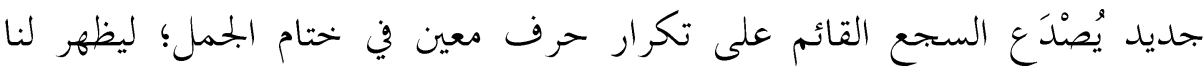

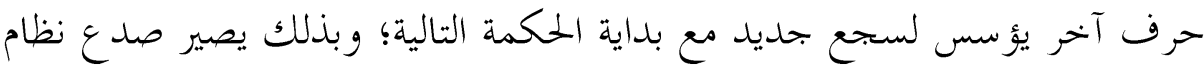

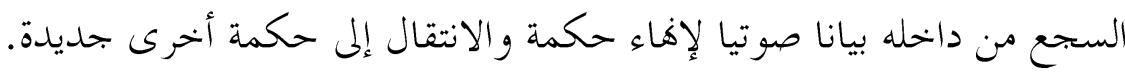

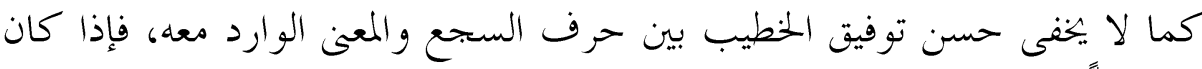

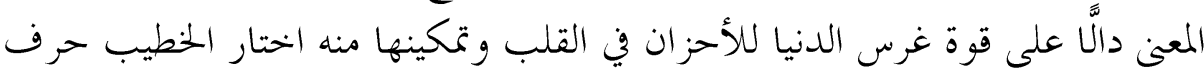

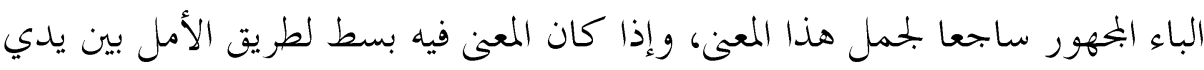

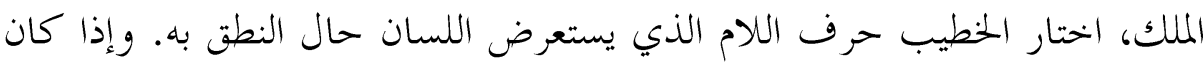

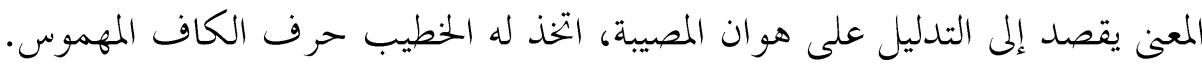

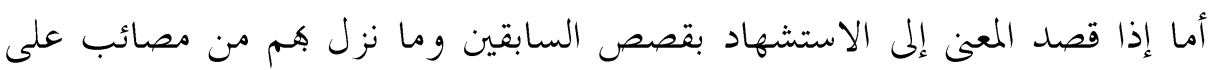

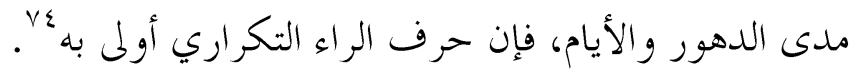




\section{$(\varepsilon)$}

وقد يتشكل النظام على أكثر من مستوى في الموضع ذاته، تثم يُصْدَع عبرها جميعا أو أو

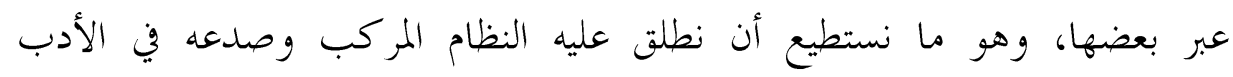
الجاهلي.

\section{$(1-\varepsilon)$}

فالشاعر الجاهلي قد يشكل مسبو كة نهوية مكونة من مشتقات صرفية ثابتة، تم

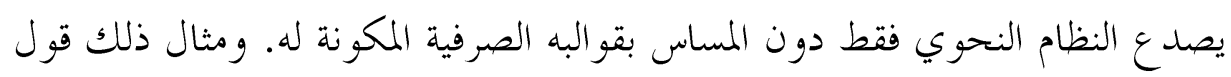
عنترة

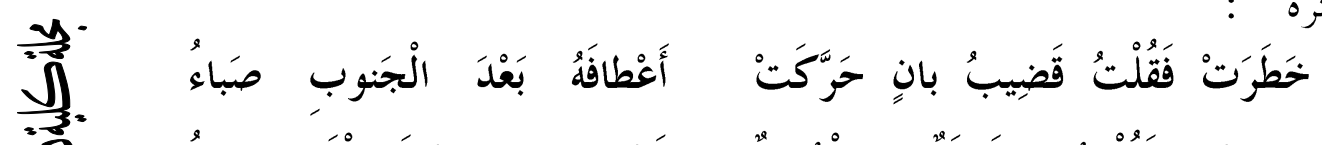

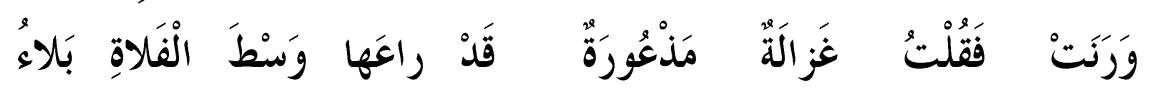

弯 rr

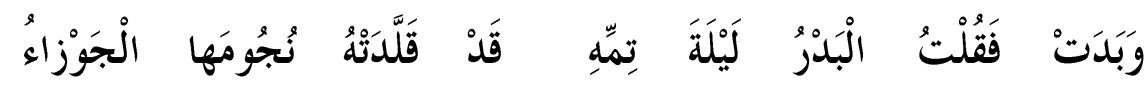

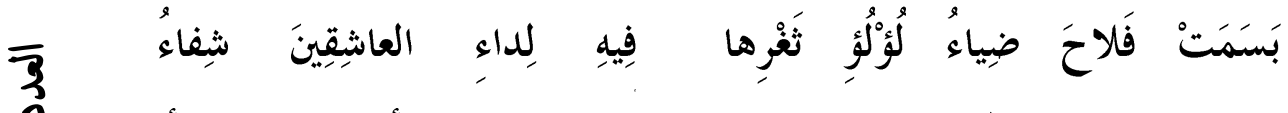

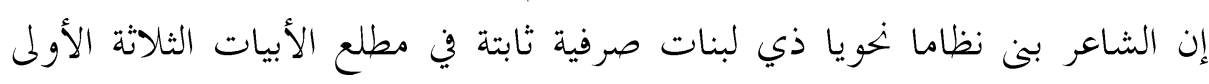
قو امها: (فعل ماض + تاء التأنيث + ضمير غائبة مستتر + فاء العطف + فعل ماض +

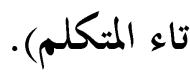
ويعكس تكرار هذا التركيب على مدى ثلاثة أبيات رؤية الشاعر للمحبوبة خحلال

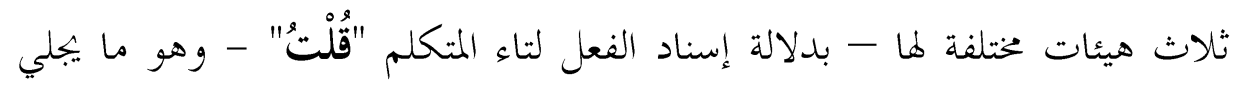
أسباب تعلق الشاعر وهيامه ها، وهو الهدف الذي تحول في البيت الرابع ليبين الشاعر

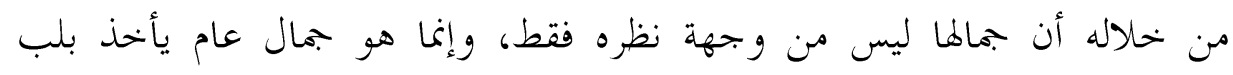

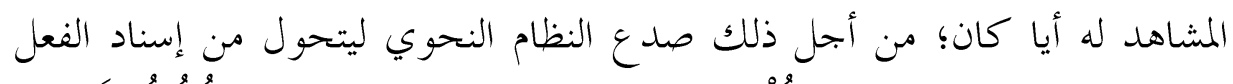

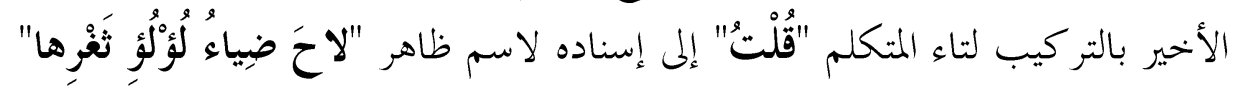

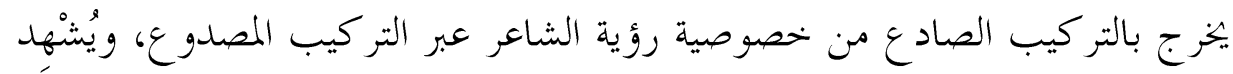

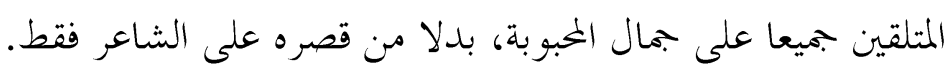




\section{$(r-\varepsilon)$}

وقد يكرر الشاعر مسبو كة نحوية مكونة من مشتقات صرفية ثابتة؛ وهو ما يُحْلِّث إيقاعا خاصا داخل البيت الشعري ذاته. وبعد هذا التكرار يبقي الشاعر على المسبو كة النحوية كما هي، ويتحول إلى صدع نظام المشتقات الصرفية من داخلها،

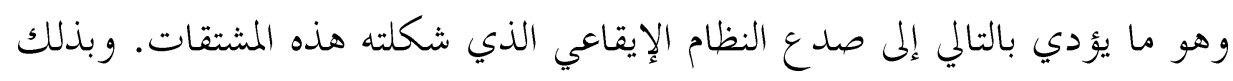
فإن النظام وصدعه يتحقق في المستويين الصري والإيقاعي داخل نظام نهوي ثابت.

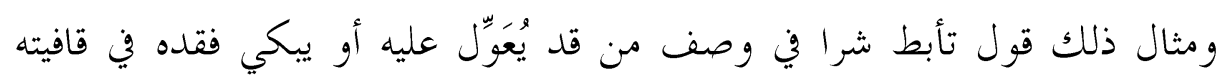
المفضلية

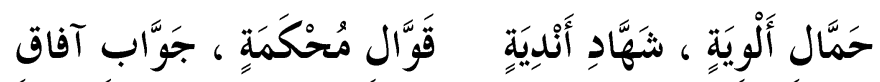

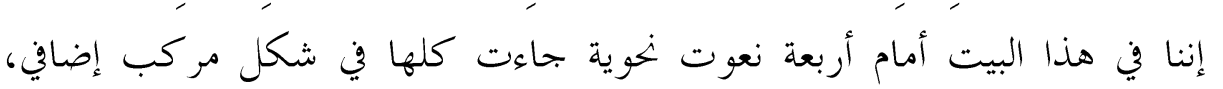

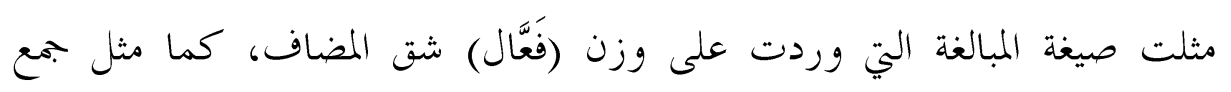

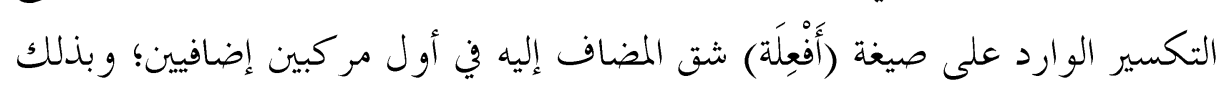

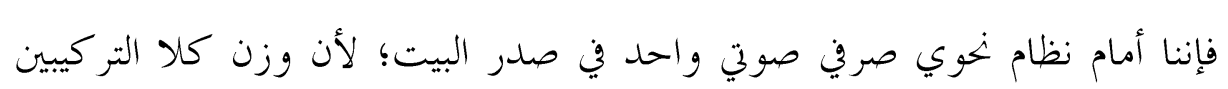

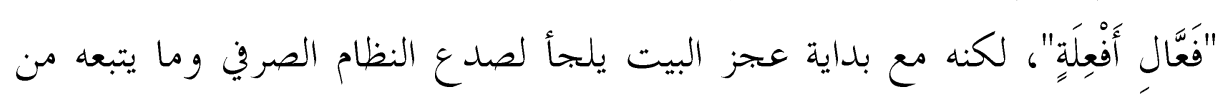

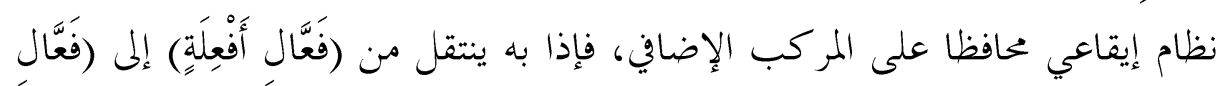

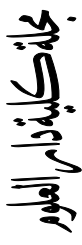
TYY

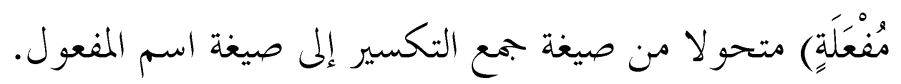
إن الشاعر حينما أقام نظاما عبر ثلاثة مستويات في صدر البيت قد أكد على الثي قيام

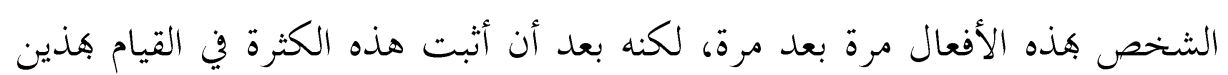

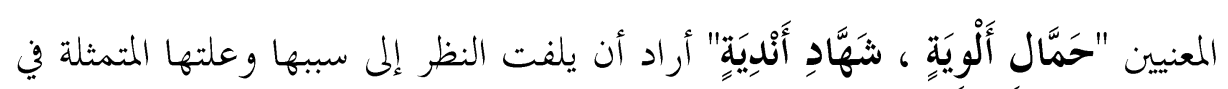

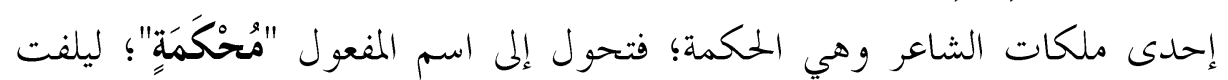

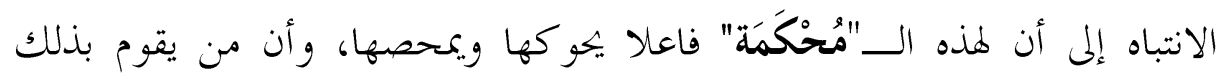
جدير بأن يكون أهل ثقة، فقدمه قومه ليحمل لواءهم في حروبهم، ويشهد أنديتهم في سلمهم. 


$$
(\boldsymbol{r}-\varepsilon)
$$

وقد يتأتى النظام المركب وصدعه على المستويات الثلاثة كلها، فيشمل الصدع المسبو كة النحوية والقو الب الصرفية و نابتها الإيقاعي. ومثال ذلك قول الخنساء في رثاء أخيها صخر

0 10

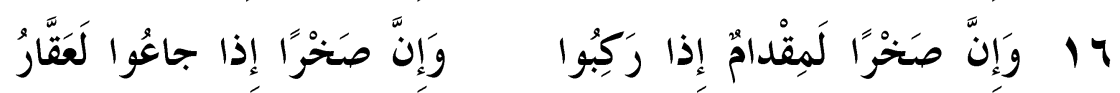

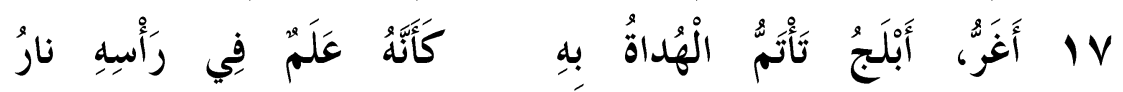

فالشاعرة بالبيت الأخير قد أقامت نظاما من خلال موالاتها بين خبرين مفردين على ل

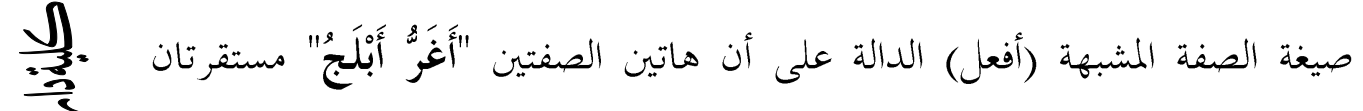

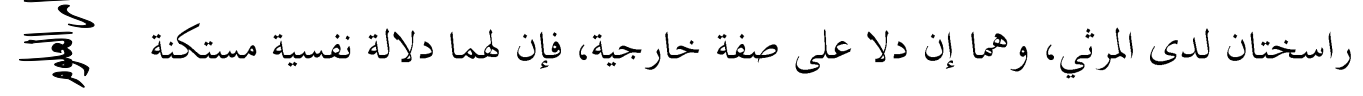

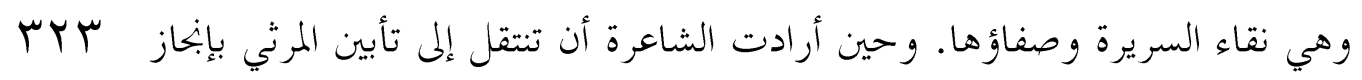

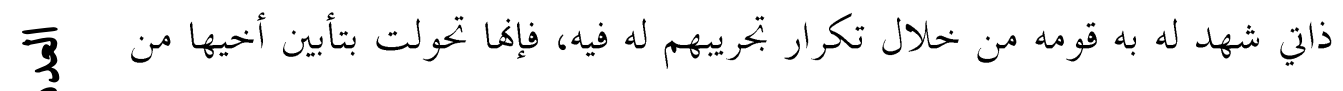

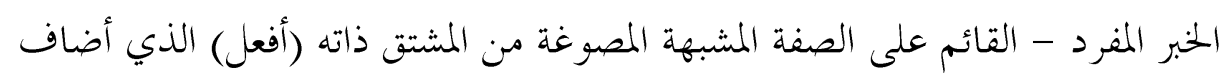
نظاما إيقاعيا - إلى الخبر الجملة القائم على الفعل المضارع؛ وبذلك فقد انصدعت

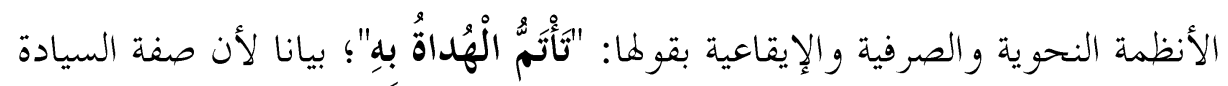
و القيادة لها خصوصية، فقد قلدها قوم المرثي له بعد تراكم بتاربه مرة تلو أخرى بدلالة توظيف الفعل المضارع - وأن هذه الصفة ليست وجهة نظر خاصة بالشاعرة تجاه أخيها، وإنما هي رأي عام لدى قوم المرثي. (०)

وأخيرا، فقد وصل بنا البحث في ختامه إلى ما يأتي : أولا - تعد فكرة النظام وصدع النظام إحدى ركائز المنهج البنيوي التي لم تنل قسطها الذي تستحقه من الدراسة النقدية التطبيقية بالوطن العربي. 
ثانيا - لفكرة النظام وصدع النظام مظهر ان، أولمما: أن يتمثل النظام خارج النص مما يشمل قواعد اللغة الصحيحة والتقاليد الفنية، في حين يتجسد صدعه داخل النص من خلال قصد الأديب لمخالفة قواعد اللغة أو الخروج عن التقاليد الفنية. وثانيهما: أن يحتوي النص من داخله النظام وصدعه، بحيث يشكل الأديب داخل النص نظاما من خلال تكرار قالب معين على أحد مستويات بنية اللغة، تم يصدع هذا النظام داخل النص ذاته من خلال توظيف قالب آخر مقابل للقالب الأول الذي صنع النظام. ثالثا - تبعا لطبيعة مسيرة الدراسات اللغوية والنقدية العربية، فإن نماذج الأدب العربي التي سنلفي ها فكرة النظام وصدع النظام بمظهرها الأول ستكون نادرة الوجود، وهو ما دعانا إلى تقييد تطبيق الفكرة بمظهرها الثاني فقط.

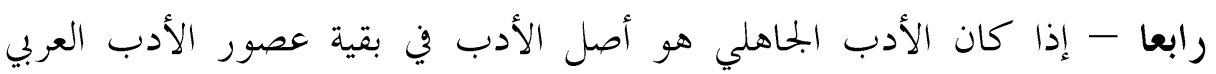

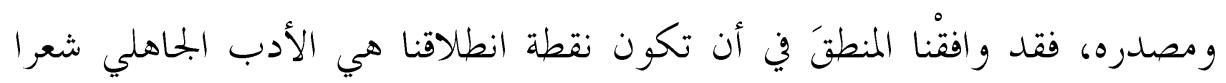

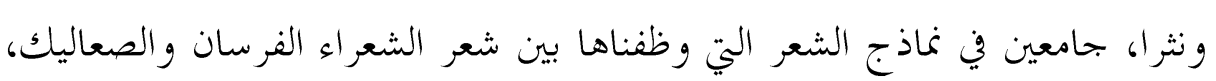

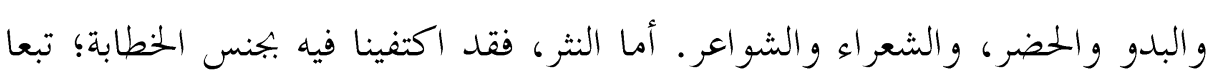

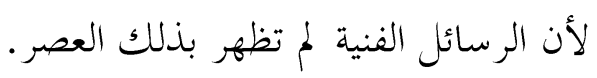
خامسا - تمخض البحث عن كشف أن فكرة النظام وصدع النظام بالأدب

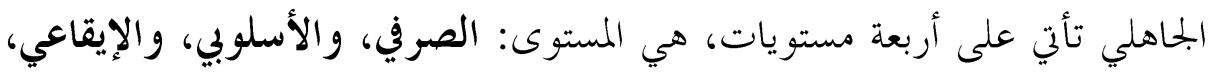

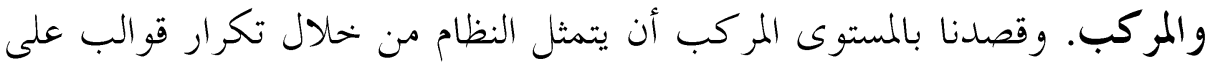

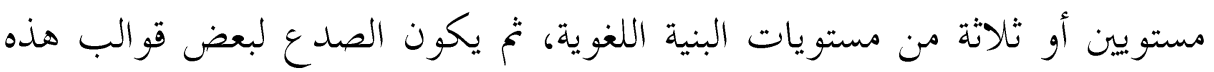

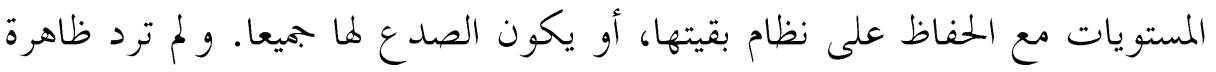

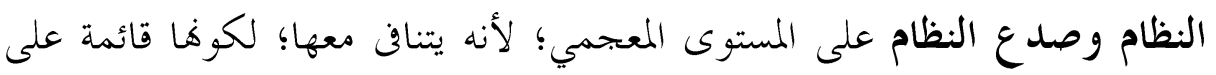
تكرار قو الب لا تكرار مادة لغوية.

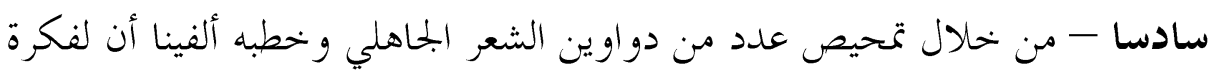

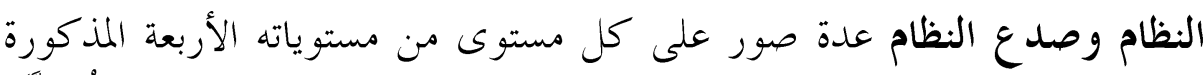

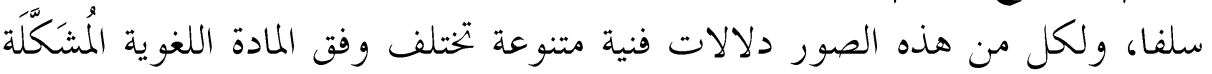


داخل قو الب ظاهرة النظام وصدعه أو السياق الخيط هـا. مع تأكيد أن للظاهرة بصورة كلية دلالات عامة تتمثل في إدهاش المتلقي وزيادة نسبة المعلوماتية

\section{|لمادروالئراجع} والإخبارية المتحققة لديه.

\section{أولا - المصادر العربية:}

الأعشى الكبير، ديوانه، تحقيق: د. محمود الرضواني، وزارة

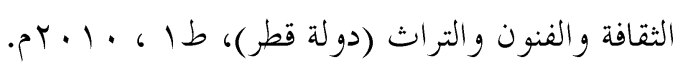

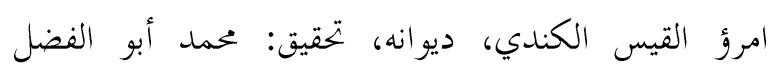

势

$$
\text { إبراهيم، دار المعارف، طه (·99 19). }
$$

تأبط شرا، ديوان تأبط شرا وأخباره، تحقيق: علي ذو الفقار

$$
\text { شاكر، دار الغرب الإسلامي، طا ، (ع .ـ اهـ - ع } 919 \text { ام). }
$$

rTo

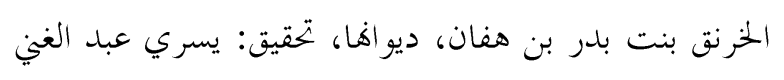

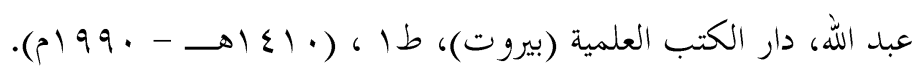

$\overline{3}$
3
0

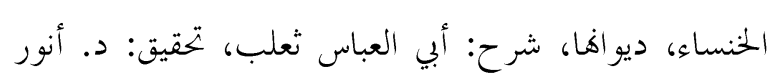

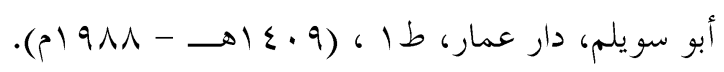

دريد بن الصمة، ديوانه، تحقيق: د. عمر عبد الرسول، دار

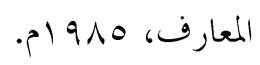

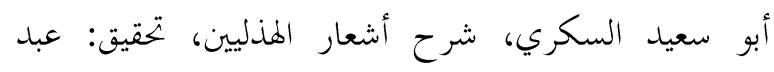

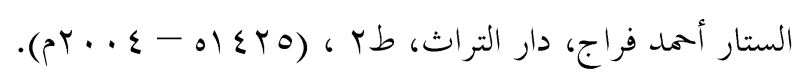

عبيد بن الأبرص، ديوانه، تحقيق: د. حسين نصار، مصطفى

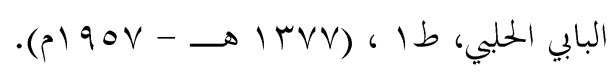

عدي بن زيد، ديوانه، تحقيق: محمد جبار المعيبد، وزارة

$$
\text { الثقافة والإرشاد بالعراق، (10 آهـ - } 1970 \text { (1)م). }
$$

عروة بن الورد، ديوانه، تحقيق : د / سعدي ضناوي، دار

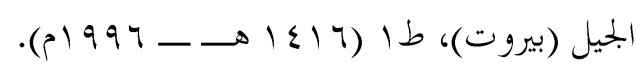


11 ا. عمرو بن كلثوم، ديوان الحارث بن حلزة وعمرو بن كلثوم، تحقيق وشرح: بجيد

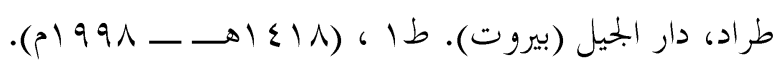

با. عنترة بن شداد العبسي، أشعار عنترة العبسي، تحقيق: د. محمد عبد المنعم خفاجي،

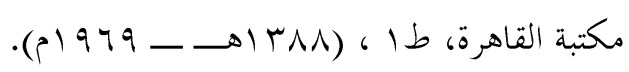

rا. المرقش الأكبر، ديوان المرقشين، تحقيق: كارين صادر، دار صادر، طا ، 991 ام ـ ع ا. المفضل الضبي، المفضليات، تحقيق: أحمد محمد شاكر وعبد السلام هارون، دار

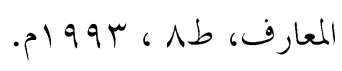

10. النابغة الذبياني، ديوانه، تمقيق: محمد أبو الفضل إبراهيم، دار المعارف، طب ، .199

17 ا ـ هبة الله بن الشجري، مختارات شعراء العرب، تحقيق: علي محمد البجاوي، دار الجليل،

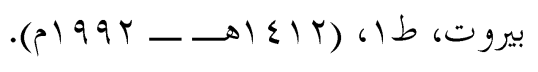

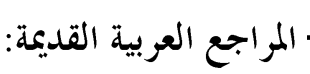

V ا. ابن الأثير، المثل السائر، تحقيق: د. أحمد الحوفي، ود. بدوي طبانة، هضة مصر، (د ـ

$$
\text { (ت) }
$$

1 ا. أبو العباس القلقشندي، صبح الأعشى في صناعة الإنشا، دار الكتب المصرية، طا ،

$$
\text { (b) }(9 T r-ه 1 r \varepsilon \cdot)
$$

9 1. عبد القادر البغدادي، خزانة الأدب ولب لباب لسان العرب، تحقيق: عبد السلام

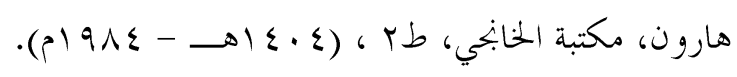

•r. عبد القاهر الجرجاني، دلائل الإعجاز، تحقيق: محمود محمد شاكر، مطبعة المدني، طب

$$
\cdot(\text { ) } 99 r-\rightarrow 1 \leqslant 1 r) 6
$$

اب. أبو عبد الله المرزباني، الموشح في مآخذ العلماء على الشعراء، تحقيق: محمد حسين

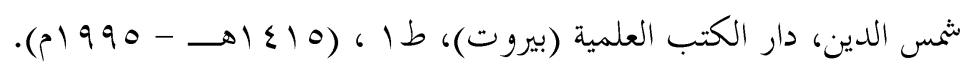

r T. أبو علي القالي، الأمالي، تحقيق : لجنة علمية بدار الكتب المصرية، الهيئة العامة لقصور

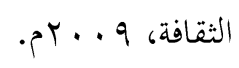


rr. أبو الفرج الأصفهاني، الأغاني، تحقيق: لجنة بإشراف محمد أبو الفضل إبراهيم، الهيئة

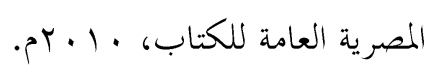

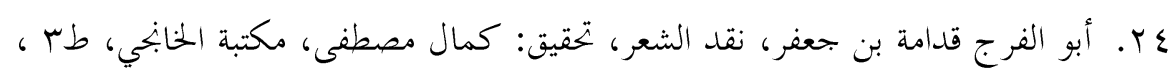

$$
\text { ( () } 19 \vee \wedge-\rightarrow 149 \lambda)
$$

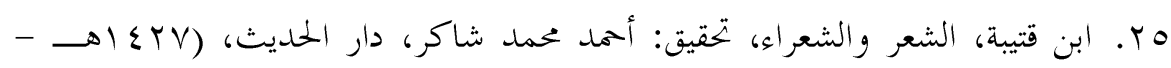

$$
\cdot(\text { Pr. T }
$$

بr. محمد بن سلام الجمحي، طبقات فحول الشعراء، تحقيق: محمود محمد شاكر، دار

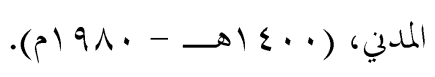

$$
\text { ثالثا - المراجع العربية الحديثة: (النية }
$$

rV

$$
\text { ( () } 1994-\rightarrow 1 \leqslant 1 r)
$$

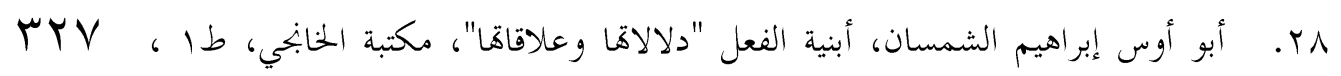

$$
\text { ( () } 9 \wedge \vee-\rightarrow 1 \leqslant \cdot \vee)
$$

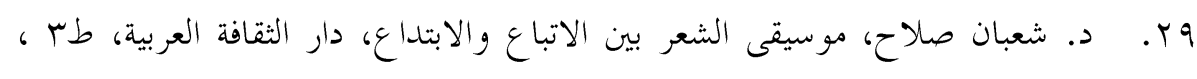

$$
\cdot(\text { ( } 1991-\longrightarrow 1 \leqslant 11)
$$

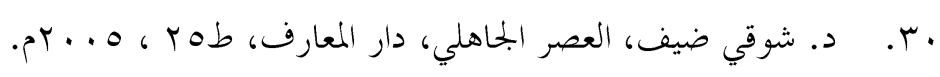

اس. . د. صلاح رزق، كلاسيكيات الشعر العربي "المعلقات العشر: دراسة في التشكيل

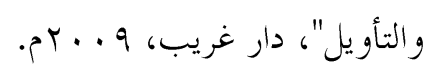

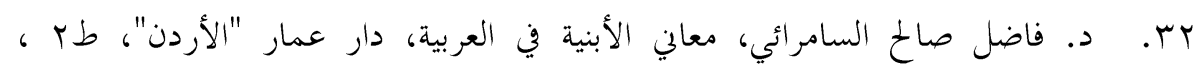

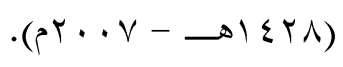

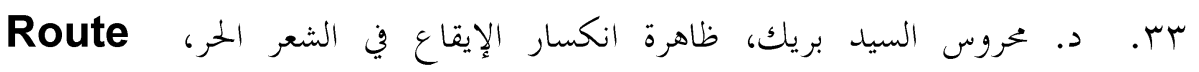
Educational and Social Science Journal

$$
\text { يوليو 11 إن بم. }
$$

گr. د. محمد محمد أبو موسى، الشعر الجحاهلي "دراسة في منازع الشعراء"، مكتبة وهبة،

$$
\text { ط }
$$


هـ. معتز قصي ياسين، التحولات الدلالية للأنساق المقطعية في قصيدة "غريب على الخليج" للشاعر بلدر شاكر السياب، بحلة الخليج العربي، المحلد .ع ، العدد (ب - ع)،

$$
\cdot 5 r \cdot 1 r
$$

جب. د. يوسف خليف، دراسات في الشعر الجاهلي، دار غريب، ا919 ام .

$$
\text { رابعا - المراجع الأجنبية المتر.جة: }
$$

VV. ميخائيلوفيتش لوتحان، تحليل النص الشعري "مهاد نقدي"، ترجة: د. محمد

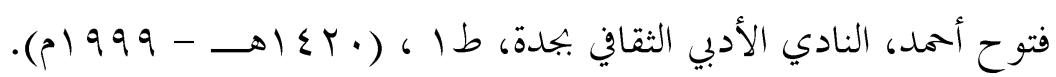

\section{الهوامش والإحالات :}

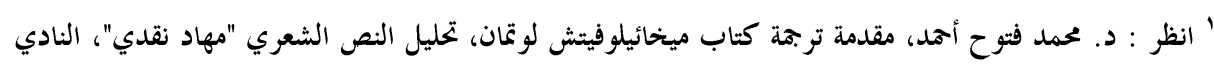

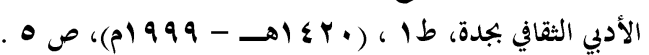

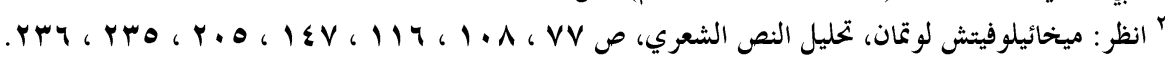

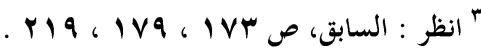

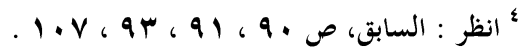

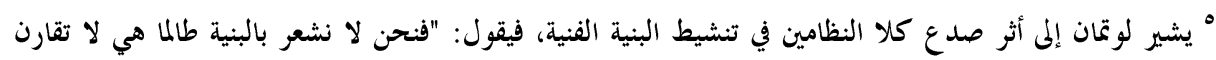

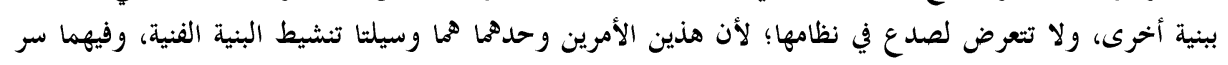

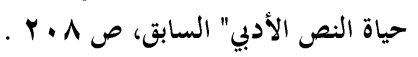

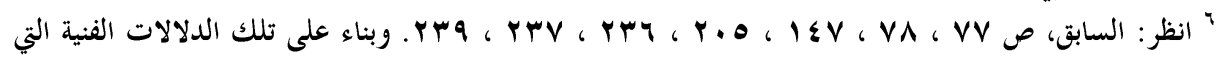

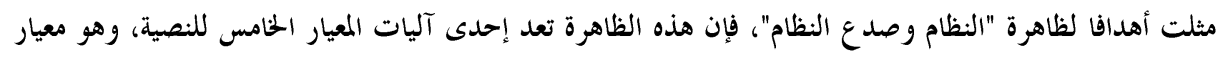

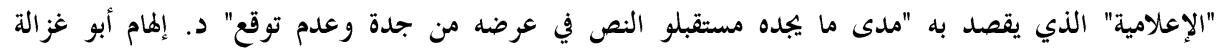

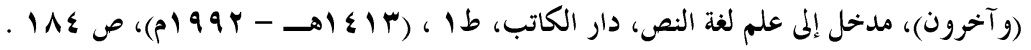

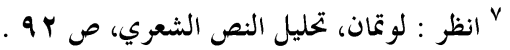

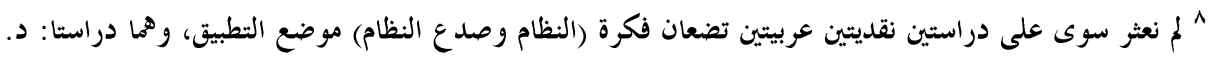

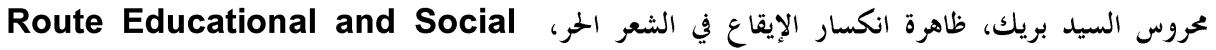
ف Science Journal

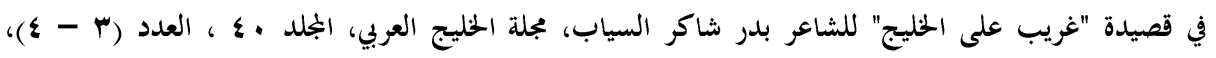

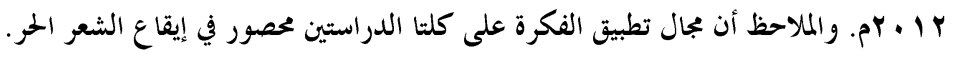

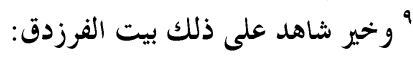

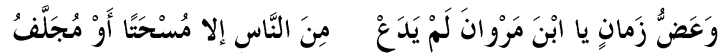

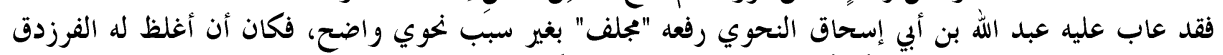

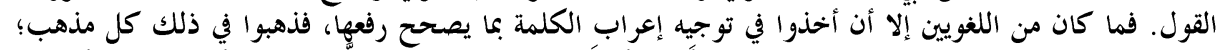

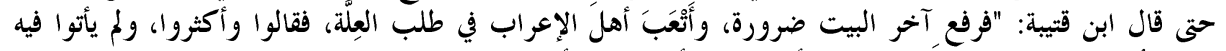

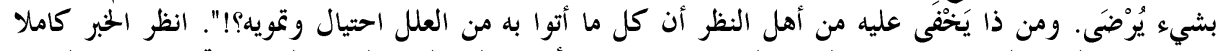

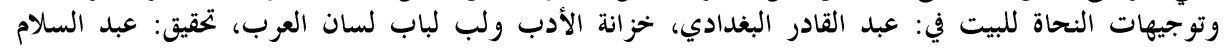




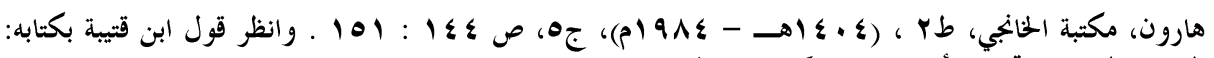

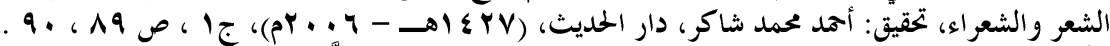

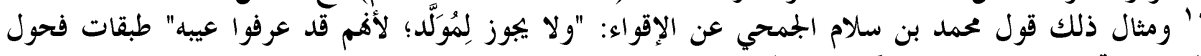

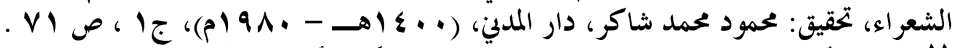

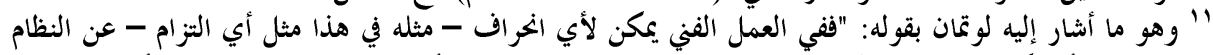

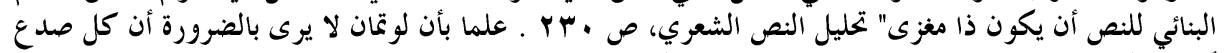

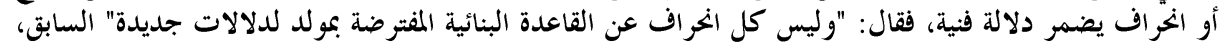

Q

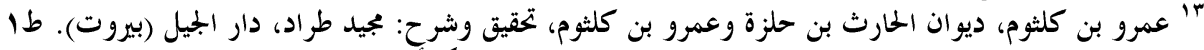

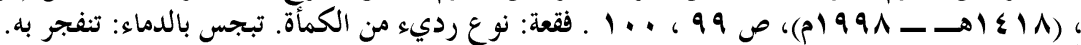

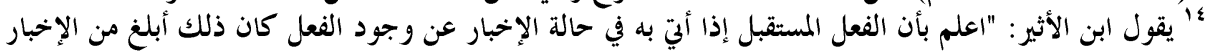

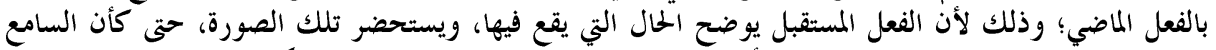

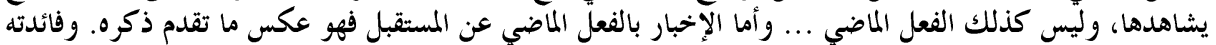

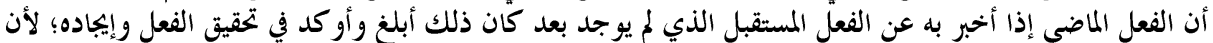

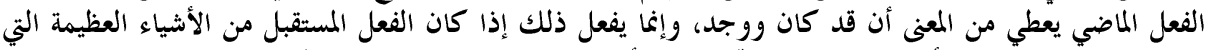

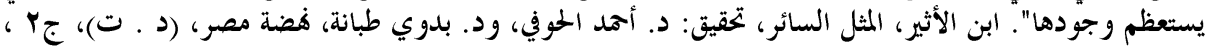

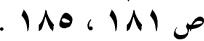

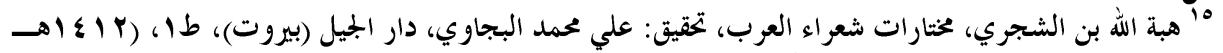

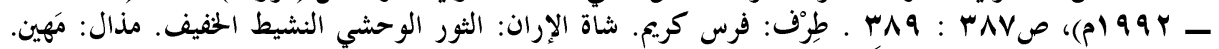

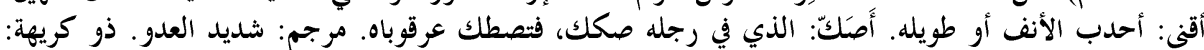

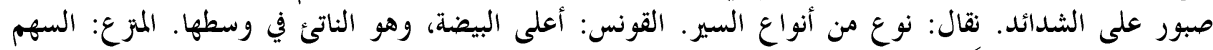

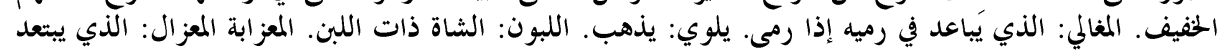

بإبله مخافة الغارة عليها وسلبها.

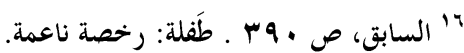

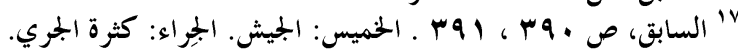

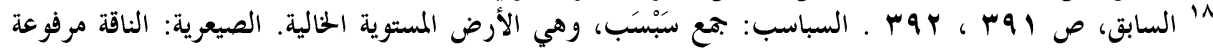

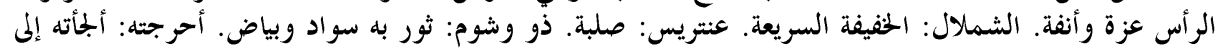

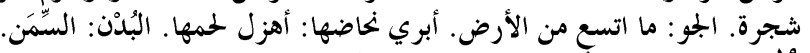

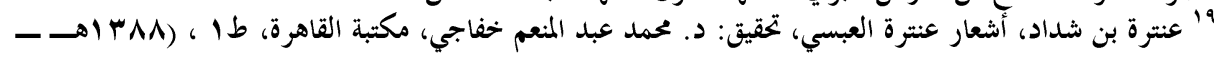

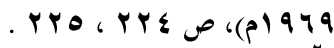

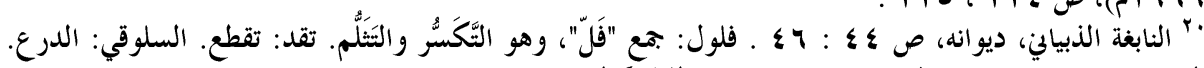

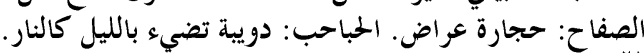

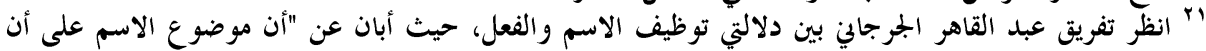

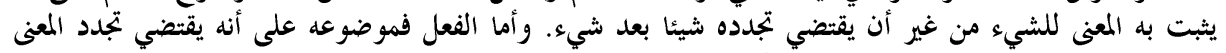

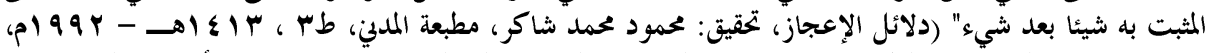

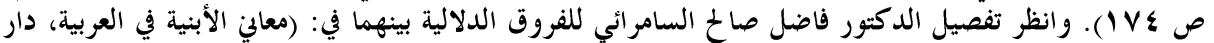

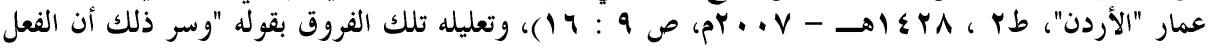

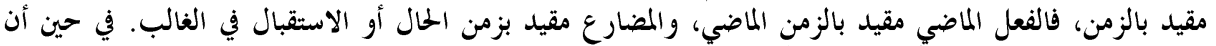

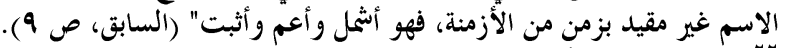

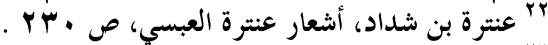

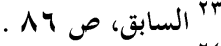

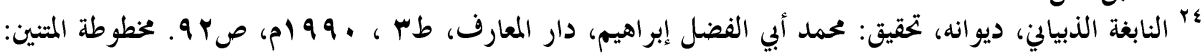

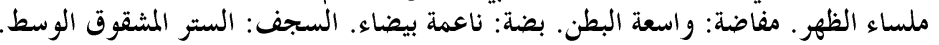




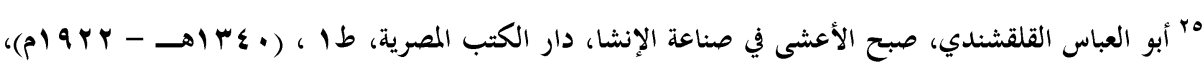

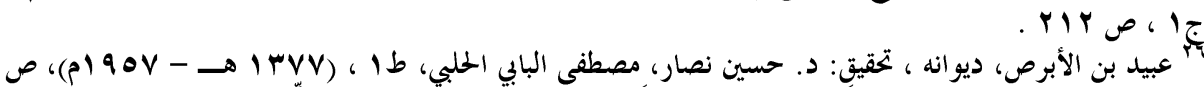

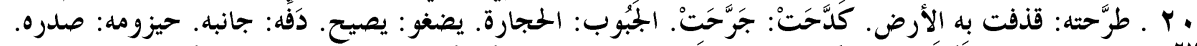

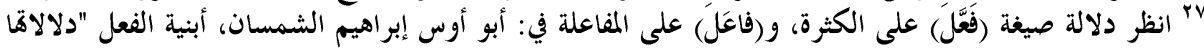

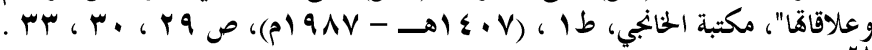

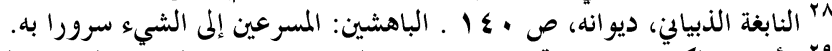

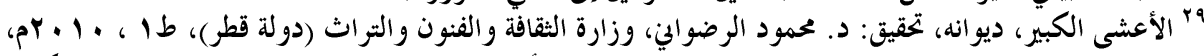

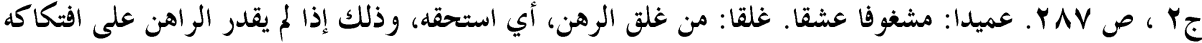

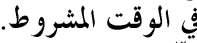

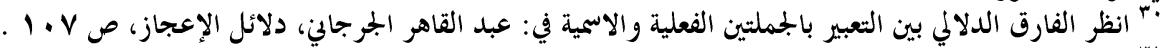

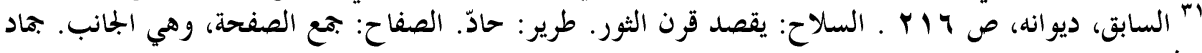

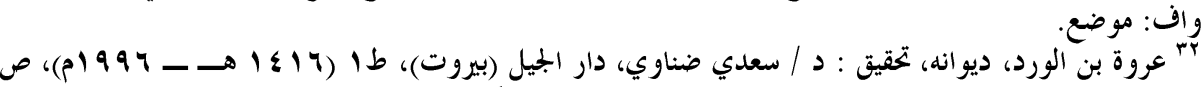

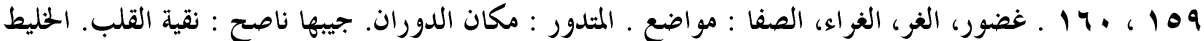

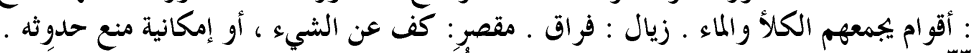

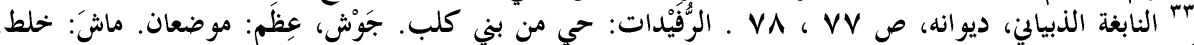

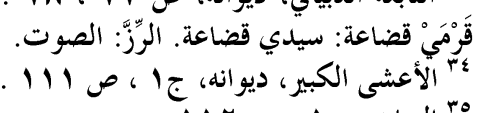

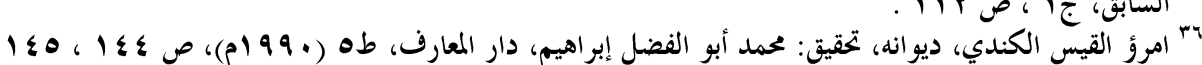

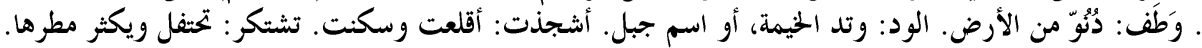

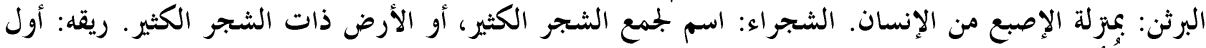

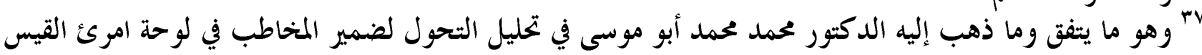

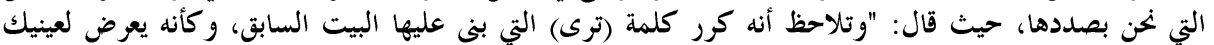

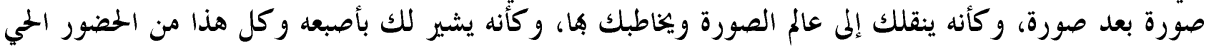

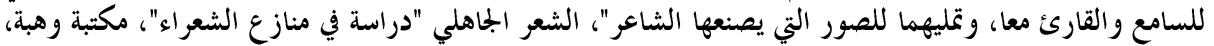

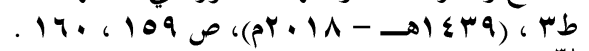

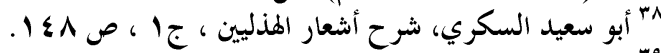

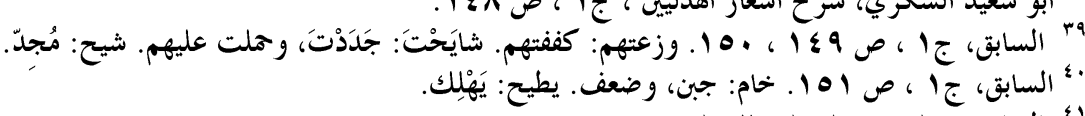

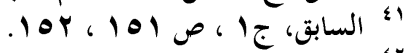

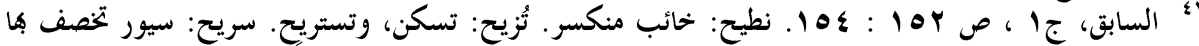

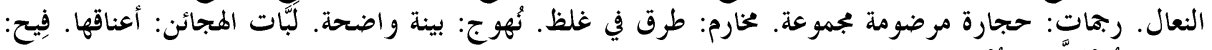

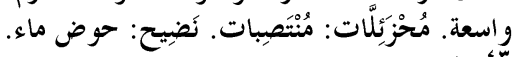

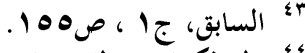

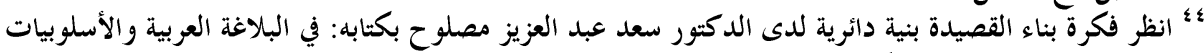

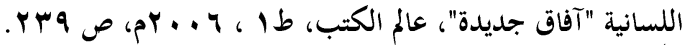

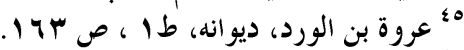

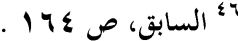

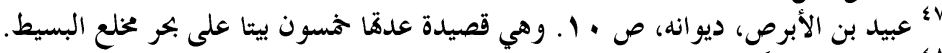

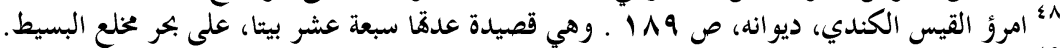

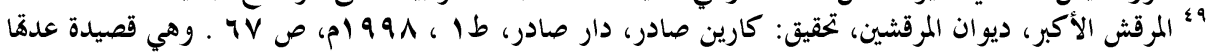

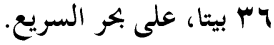




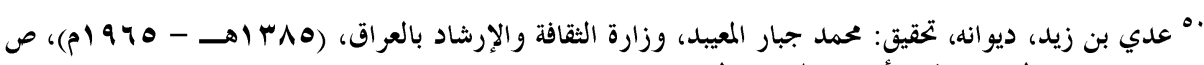
10V

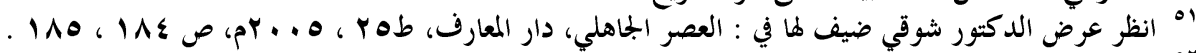

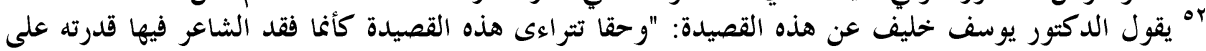

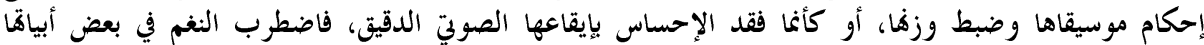

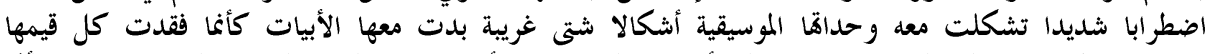

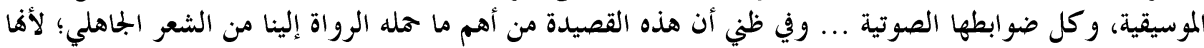

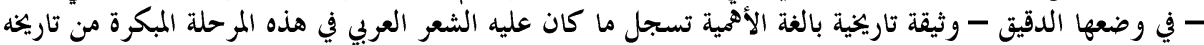

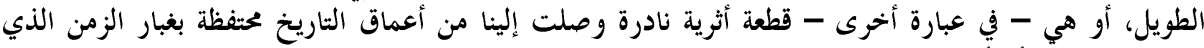

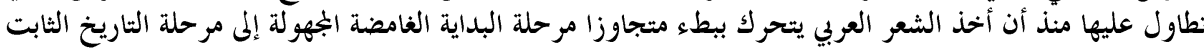

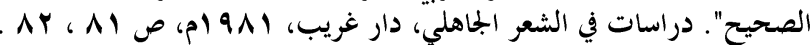

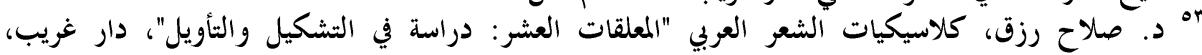

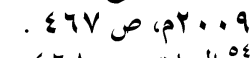

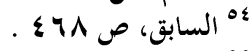

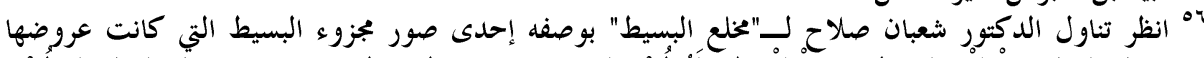

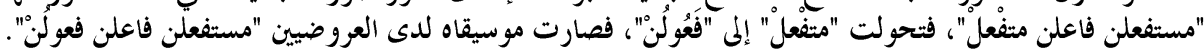

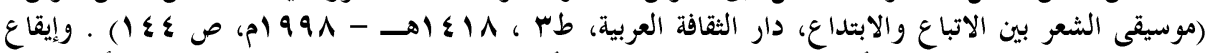

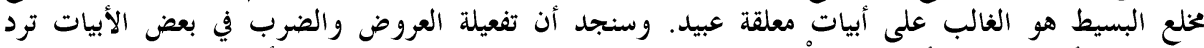

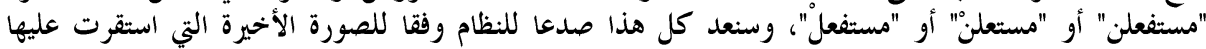

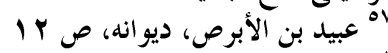

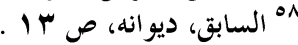

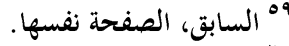

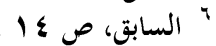

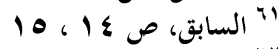

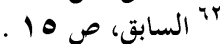
آّ انظر : أبو عبد الله المرزبالي، الموشح في مآخذ العلماء على الشعراء، تحقيق: محمد حسين شثس الدين، دار الكتب

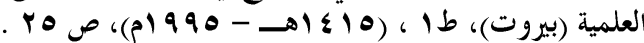

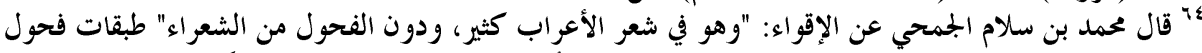

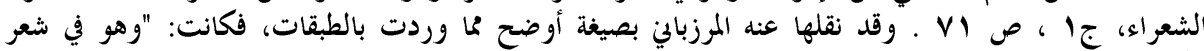

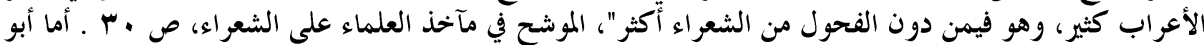

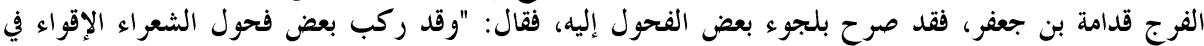

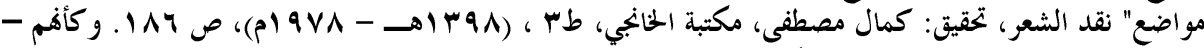

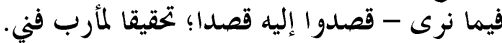

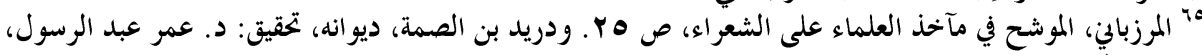

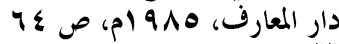

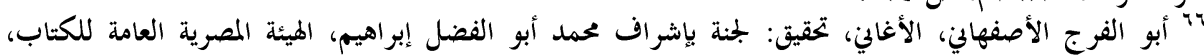

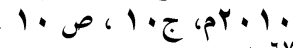

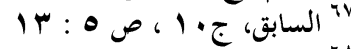

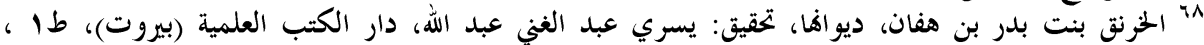

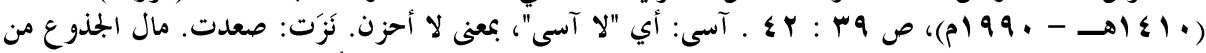

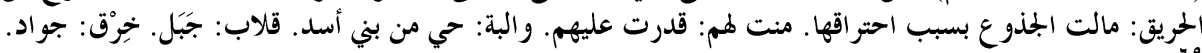

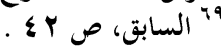

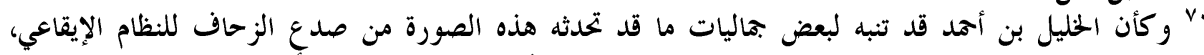

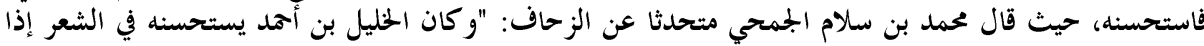




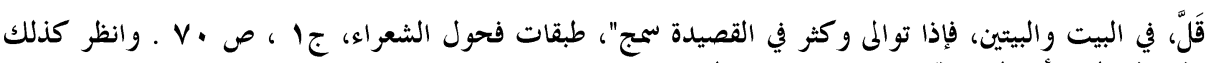

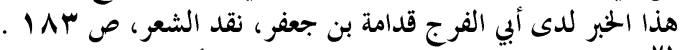

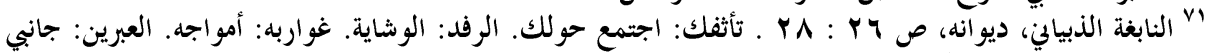

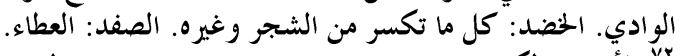

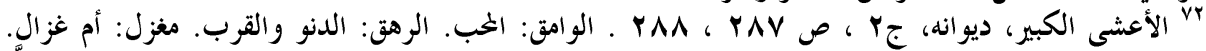

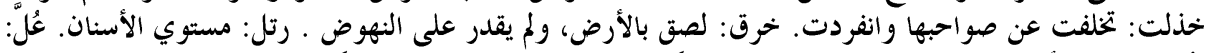

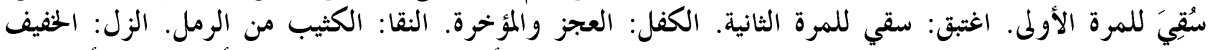

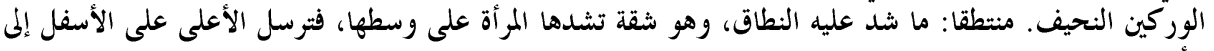

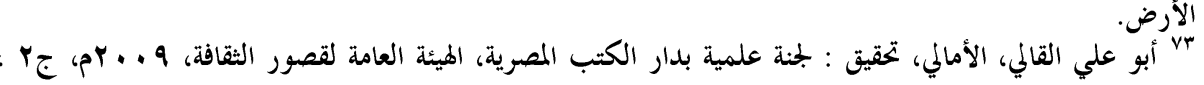

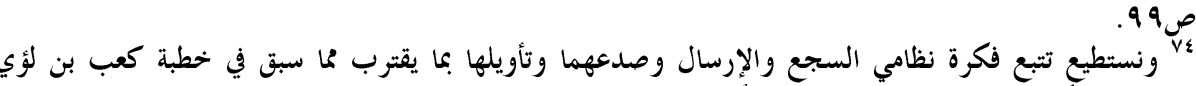

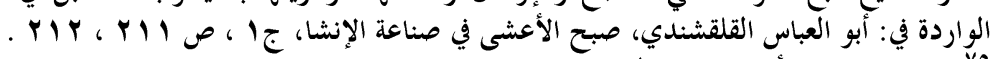

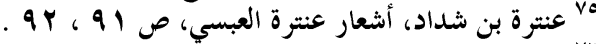

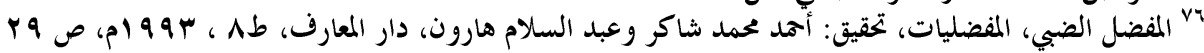

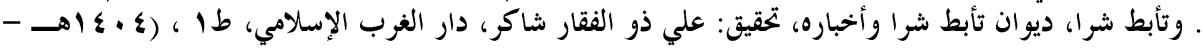

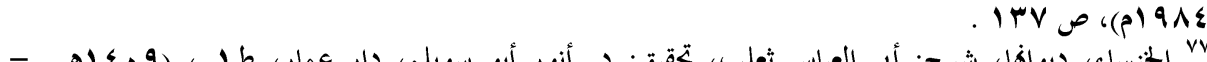

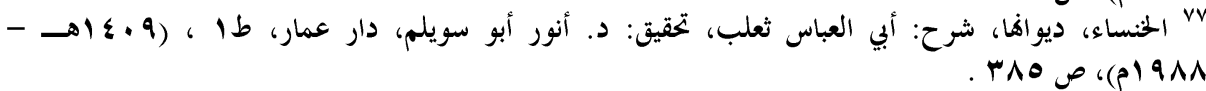

